\title{
Systematics of the subfamily Poeciliinae Bonaparte (Cyprinodontiformes: Poeciliidae), with an emphasis on the tribe Cnesterodontini Hubbs
}

\author{
Paulo Henrique Franco Lucinda* and Roberto E. Reis**
}

Osteological and soft anatomical features of representatives of poeciliine genera were studied to test the monophyly of the poeciliine tribes and to advance a hypothesis of relationships within the subfamily. The resultant hypothesis supports the proposal of a new classification for the subfamily Poeciliinae. Diagnoses are provided for suprageneric clades. The tribe Tomeurini is resurrected and the new tribes Brachyrhaphini and Priapichthyini as well as the supertribe Poeciliini are described. New usages of old tribe names are proposed based on the phylogenetic framework.

Caracteres osteológicos e da anatomia mole de representantes dos gêneros de poeciliíneos foram estudados para se testar a monofilia das tribos de Poeciliinae e para propor uma hipótese de relações dentro da subfamília. A hipótese resultante suporta a proposição de uma nova classificação para a subfamília Poeciliinae. São fornecidas diagnoses para os clados supragenêricos. A tribo Tomeurini é ressuscitada e as novas tribos Brachyrhaphini e Priapichthyini bem como a supertribo Poeciliini são descritas. Novos usos para antigos nomes de tribos são propostos com base no arranjo filogenético.

Key words: Alfarini, Brachyrhaphini, Gambusiini, Girardinini, Heterandriini, Priapellini, Priapichthyini, Poeciliini, Tomeurini.

\section{Introduction}

This paper is resultant from a project that intended to perform the taxonomic revision of the tribe Cnesterodontini, as well as to propose a phylogenetic hypothesis of relationships among its members. Testing the monophyly of the Cnesterodontini was the first step attempting to achieve our aims. Thus, the original project was broadened to embrace a phylogenetic hypothesis of relationships and the proposal of a provisional classification for the subfamily Poeciliinae. The resultant hypothesis included representatives of all poeciliine genera, and all described Cnesterodontini species, as well as 24 new species revealed by the taxonomic revisions of genera Cnesterodon Garman, Phallotorynus Henn, and Phalloceros Eigenmann. Intrageneric relationships of Phalloptychus Eigenmann, Cnesterodon, Phalloceros, and Phallotorynus are provided herein, but will be discussed in the aforementioned taxonomic revisions.

\section{Nomenclatural and Taxonomic History}

Poeciliinae. The subfamily Poeciliinae is a cyprinodontiform group widely distributed throughout the Americas. Poeciliinae is the sister group of the Procatopodinae, a group composed of the South-American Fluviphylax Whitley and the African procatopodines. The clade Poeciliinae plus Procatopodinae is the sister group of the Aplocheilichthyinae (Costa, 1996; Ghedotti, 2000). These three subfamilies compose the family Poeciliidae. The Poeciliinae embraces approximately two hundred twenty species currently allocated in approximately twenty-eight genera (Lucinda, 2003). Theses fishes are characterized by the uniquely derived possession of a gonopodium formed by the modified male anal-fin rays 3, 4, and 5 (Parenti, 1981).

The Poeciliinae includes well-known aquarium fishes such as the guppies, mosquito fishes, swordtails, platys, and mollies. Poeciliines are well known subjects of study for ecologists, anatomists, embryologists, and other research-

\footnotetext{
* Laboratório de Ictiologia Sistemática, Universidade Federal do Tocantins, Campus de Porto Nacional, rua 3, Quadra 17, s/n, Caixa Postal 136, 77500-000 Porto Nacional, TO, Brazil. e-mail:lucinda@uft.edu.br

** Laboratório de Ictiologia, Pontifícia Universidade Católica do Rio Grande do Sul. Av. Ipiranga, 6681, Caixa Postal 1429, $90619-900$ Porto Alegre, RS, Brazil. e-mail: reis@ pucrs.br
} 
ers. Notwithstanding, this fish assemblage is only superficially studied from the perspective of systematics. Intrageneric diversity and intergeneric relationships of the Poeciliinae are poorly known, regardless of its huge distribution, range, and notoriety. Similarly, phylogenetic hypotheses for most genera are still wanting.

Taxonomic revisions and phylogenetic analyses have provided some insight into the relationships of smaller groups of the Poeciliinae (e.g., Rosen, 1967, 1979; Rauchenberger, 1989; Rosa \& Costa, 1993; Meyer et al., 1994; Mojica et al., 1997; Rodriguez, 1997; Poeser, 2003) or have dealt with higher taxa (Rosen, 1964; Parenti, 1981; Costa, 1996, 1998; Ghedotti, 2000). The only comprehensive study is the classic revision of "Poeciliidae" by Rosen \& Bailey (1963), which did not deal with cladistic methodology. Nonetheless, Rosen \& Bailey (1963) is the basis for the current internal classification of Poeciliinae. Later, Parenti \& Rauchenberger (1989) modified the classification of Rosen \& Bailey (1963) in order to accommodate it into the taxonomic rank of subfamily proposed by Parenti (1981) (Table 1). Following Rosen \& Bailey (1963) and Parenti \& Rauchenberger (1989), Tomeurus Eigenmann alone is the supertribe Tomeurini. The remaining genera form the supertribe Poeciliini, which is subdivided in the tribes Poeciliini, Cnesterodontini, Gambusiini, Scolichthyini, Girardinini, Heterandriini, and Xenodexini. Later, Ghedotti (2000) proposed another classification for the Poeciliinae (Table 2) based in his phylogenetic study of the Poecilioidea despite the fact that only 12 genera were examined in his cladistic analysis.

The history of the subfamily began in 1801 with the description of Poecilia vivipara Bloch \& Schneider as new genus and new species. Before establishment as a distinct family, the history of the Poeciliidae is merged with that of other cyprinodontiform families and with the Cyprinidae.

Table 1. Classification of Poeciliinae (Rosen \& Bailey, 1963 and Parenti \& Rauchenberger, 1989).

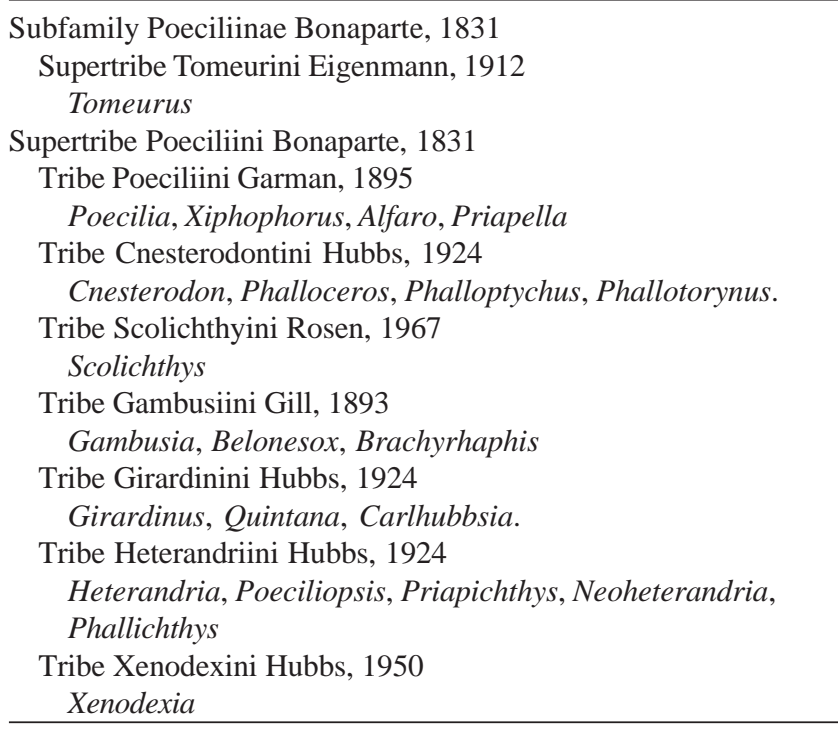

Table 2. Classification of Poeciliinae (Ghedotti, 2000)

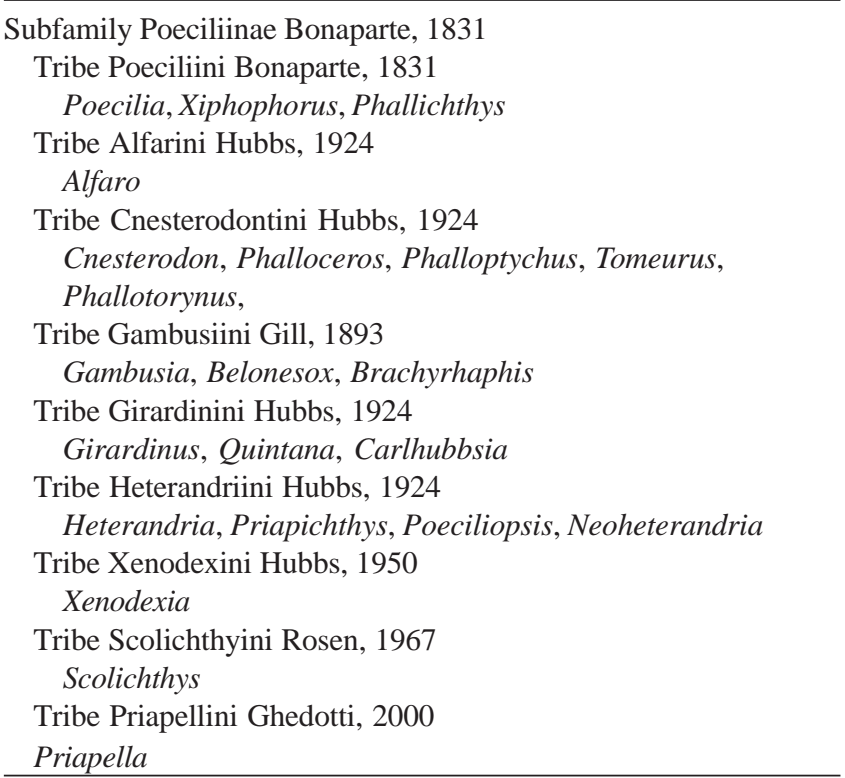

Rafinesque (1810) created the "Ordini Cyprinidi"; this group contained a species of Mugil Linnaeus and three species of Cyprinus Linnaeus. Later Wagner (1828) created the family "Cyprinöidae" including the genera Lebias Goldfuss, Poecilia Bloch \& Schneider, Fundulus Lacepède, Cyprinodon Lacepède, and Mollienesia Lesueur. The word "Cyprinöidae" is etymologically identical to "Cyprinidi", for they share the same stem. Thus, Wagner failed to coin a new name. Cuvier (1829) and Cuvier \& Valenciennes (1846) followed Rafinesque (1810) employing the name "Cyprinöides" and "Cyprins". Bonaparte (1831) also accepted the "Ordini Cyprinidi" of Rafinesque (regarding it as a family), but divided it in three groups: Cyprinini, Anableptini, and Poecilini [sic]. The Poecilini was removed from the Cyprinidae by Bonaparte (1840) to form a separate family Poecilidae [sic] (including Anableptini and Poecilini). Four years before Bonaparte, Agassiz (1834) had already separated the Cyprinodonts and the Cyprinidae, removing Anableps Scopoli, Poecilia, Lebias, Fundulus, Mollienesia, and Cyprinodon to a new family "Cyprinodontes". Swainson (1838) placed Poeciliinae as a subfamily of Cobitidae. Gill (1857) adopted the name Cyprinodontes and later (Gill, 1865; 1894) employed Poeciliidae. Gill (1872) also used the name Cyprinodontidae as a subgroup of the Haplomi, which also included the Amblyopsidae, Esocidae, and Umbridae. Günther (1866) created the genus Platypoecilus Günther and adopted Cyprinodontidae as family name, dividing it in Cyprinodontidae Limnophagae (=poeciliines) and Cyprinodontidae Carnivorae (=remaining Cyprinodontiformes).

At the same time, new genera have been proposed: Mollienesia, Xiphophorus Heckel and Heterandria Agassiz. Poey (1854) added three new genera: Girardinus Poey, Limia Poey, and Gambusia Poey. Belonesox Kner was created in 1860 . In the same year the genera Hemixiphophorus Bleeker and Pseudoxiphophorus Bleeker 
were erected. Soon after, De Filippi (1861) created Lebistes De Filippi and Steindachner (1863) erected Poeciliodes Steindachner.

Garman (1895) adopted the family name Cyprinodontes and recognized eight subfamilies: Cyprinodontinae (Cyprinodon, Tellia Gervais, Lebias, Characodon Günther, Girardinichthys Bleeker, Neolebias Steindachner), Jenynsiinae (Jenynsia Günther), Anablepinae (Anableps), Haplochilinae [sic] (Orestias Valenciennes, Empetrichthys Gilbert, Lucania Girard, Haplochilus [sic, = Aplocheilus McClelland], Fundulus, Adinia Girard, Fundulichthys Bleeker, Zygonectes Agassiz, Rivulus Poey, Cynolebias Steindachner, Pterolebias, Garman, Haplochilichthys [sic, = Aplocheilichthys Bleeker], Nothobranchius Peters, Gambusiinae (Gambusia, Belonesox, Pseudoxiphophorus, Heterandria) and Poeciliinae (Poecilia, Girardinus, Platypoecilus, Mollienesia, Xiphophorus). Garman (1895) also proposed two new genera (Glaridodon Garman and Cnesterodon) in Poeciliinae.

Eigenmann (1903) created the genus Toxus Eigenmann. Paragambusia Meek was proposed in 1904. Eigenmann (1907) studied the intromittent organ in poeciliids of the La Plata and found that it is formed by the third, fourth, and fifth analfin rays. In that paper he erected the genera Acanthophacelus Eigenmann Phalloceros and Phalloptychus. Soon after, Regan (1908) erected Petalosoma Regan and Eigenmann (1909) created Tomeurus.

Regan (1911) employed the name Microcyprini [= Cyprinodontes of Garman] adding the Amblyopsidae (suborder Amblypsoidae) to this group. He allocated the remaining species in the Poecilioidea, with one family Poeciliidae divided in seven subfamilies: Cyprinodontinae, Fundulinae, Orestiinae, Characodontinae, Jenynsiinae, Anablepinae, and Poeciliinae. Regan merged the Gambusiinae and Poeciliinae of Garman, recognizing the genera Acanthophacelus and Petalosoma and adding Phalloceros and Phalloptychus. Regan (1911) was the first to define the Poeciliinae by two exclusive characters: absence of exoccipital condyles and male anal-fin rays modified into a gonopodium.

Meek (1912) proposed the genus Alfaro Meek and treated it as a Tomeurinae. Regan (1912) erected Petalurichthys Regan, unneeded replacement name for Petalosoma preoccupied in Coleoptera. Petalurichthys published November 1912 is an objective synonym of Alfaro Meek September 12th, 1912.

Regan (1913) completed the first comprehensive revision of the Poeciliinae proposing eight new genera: Priapichthys Regan, Priapella Regan, Pseudopoecilia Regan, Poeciliopsis Regan, Brachyrhaphis Regan, Leptorhaphis Regan, Pamphorichthys Regan, and Pamphoria Regan. Langer (1913) created Gulapinnus Langer, a junior objective synonym of Cnesterodon. Regan (1914) proposed Heterophallus Regan.

Henn (1916) adopted the classification of Regan (1911) and created new poeciliine genera Diphyacantha Henn, Neoheterandria Henn, and Phallotorynus. Hubbs (1924) proposed the genera Alloheterandria Hubbs, Allogambusia Hubbs, Allopoecilia Hubbs, Darienichthys Hubbs, Neopoecilia Hubbs, Phallichthys Hubbs, Panamichthys
Hubbs, Parapoecilia Hubbs, and Xenophallus Hubbs, and recognized four subfamilies (Tomeurinae, Gambusiinae, Poeciliinae, and Poeciliopsinae) and nine tribes within the Poeciliidae (Poeciliinae sensu Parenti, 1981). Hubbs (1924) considered the Gambusiinae as the least specialized poeciliids whereas Tomeurus gracilis Eigenmann as the most specialized. Hubbs (1926) moved Alfaro from the Tomeurinae to the Poeciliinae leaving Tomeurus as the sole genus in the Tomeurinae. Hubbs (1926) also erected the genera Aulophallus Hubbs, Micropoecilia Hubbs, Poecilistes Hubbs, and Trigonophallus Hubbs. Subsequently, Hubbs proposed Furcipenis Hubbs, Quintana Hubbs, and Allophallus Hubbs (Hubbs, 1931; 1934; 1936, respectively).

Howell Rivero \& Hubbs (1936) recognized Alfaro as distinct from both Tomeurus and the Poeciliinae and classified this genus it in its own subfamily, Alfarinae. This taxonomic decision was supported by Rosen (1952) and Rosen \& Gordon (1953).

From 1940 to 1963 eleven new genera have been proposed: Arizonichthys Nichols, Allodontium Howell Rivero \& Rivas, Dactylophallus Howell Rivero \& Rivas, Lembesseia Fowler, Hubbsichthys Schultz, Curtipenis Rivas \& Myers, Xenodexia Hubbs, Carlhubbsia Whitley, Recepoecilia Whitley, Dicerophallus Alvarez, and Flexipenis Hubbs.

Rosen (1967) erected the poeciliid genus Scolichthys Rosen. Rivas (1980) removed Limia from the synonym of Poecilia and erected the subgenus Odontolimia Rivas, splitting Limia in two subgenera, L. (Limia) and L. (Odontolimia). Poeser (2002) created the monotypic genus Pseudolimia Poeser for Limia heterandria Regan.

Some taxonomic and phylogenetic studies have provided some progress into the relationships of smaller groups of the Poeciliinae. The genera Heterandria and Xiphophorus were reviewed by Rosen (1979), a classic paper concerning methods of biogeographical analysis. Rauchenberger (1989) put forward hypotheses of systematic and biogeographic relationships among the species of the genus Gambusia. Rosa \& Costa (1993) made a taxonomic revision of the genus Cnesterodon, describing two new species and proposing some putative synapomorphies for Cnesterodon, in the absence of a phylogenetic analysis. The phylogenetic relationships of Xiphophorus species have been surveyed by Rosen (1979), Rauchenberger et al. (1990), Meyer et al. (1994), Marcus \& McCune (1999) and Kallmann et al. (2004).

Mojica et al. (1997) proposed a hypothesis of relationships among Brachyrhaphis species on the basis on mitochondrial DNA evidence. Rodriguez (1997) studied the relationships among genera of the tribe Poeciliini sensu Rosen \& Bailey, re-defining the tribe Poeciliini as comprehending the genera Alfaro, Priapella, Xiphophorus, Poecilia, Limia and Pamphorichthys. Ptaceck \& Breden (1998) proposed a molecular phylogeny for Poecilia, focusing on the species of the subgenus Mollienesia. Breden et al. (1999) performed a phylogenetic analysis for part of the species of the genus Poecilia based on mitochondrial DNA evidence. Hamilton 
(2001) proposed a phylogenetic hypothesis for Limia species based on the mitochondrial genes sequences. Mateos et al. (2002) proposed a historical biogeography hypothesis for Poeciliopsis species based on sequence variation in two mitochondrial genes. Poeser (2003) carried out a taxonomic revision of Poecilia and proposed a phylogenetic hypothesis for this genus.

Recent phylogenetic studies have dealt with higher taxa but none has tackle the relationships among members of the subfamily Poeciliinae as a whole. The only comprehensive study is Rosen \& Bailey (1963), but these authors proposed a non-cladistic classification. In 1963, Rosen and Bailey published their classic revision of poeciliid fishes. This work separate the Poeciliidae into tree subfamilies, Tomeurinae for Tomeurus, Xenodexiinae for Xenodexia, and Poeciliinae for all other poeciliids including Alfaro, which was recognized in the tribe Poeciliini. Parenti (1981) recognized the Poeciliidae of Rosen \& Bailey as a subfamily (Poeciliinae) within a more inclusive family (Poeciliidae) including the oviparous Aplocheilichthyinae and Fluviphylacinae. Parenti \& Rauchenberger (1989) modified the classification of Rosen \& Bailey (1963) to reflect the change in taxonomic rank proposed by Parenti (1981) (Table 1). Meyer e Lydeard (1993) put forward a molecular phylogeny for Cyprinodontiformes including four poeciliine genera. Costa (1996) presented new evidence concerning the monophyly of the subfamilies of Poeciliidae, and proposed a hypothesis of phylogenetic interrelationships among them. Costa (1998) put forward a new phylogenetic framework for the Cyprinodontiformes, differing from Parenti's (1981) hypothesis. Nonetheless, Parenti (1981) and Costa $(1996,1998)$ did not tackle the inter- and intrageneric relationships. Recently, Ghedotti (2000) recognized the monophyly of the family Poeciliidae, with three monophyletic subfamilies: (1) the Aplocheilichthyinae containing solely Aplocheilichthys spilauchen, (2) the Procatopodinae containing Fluviphylax (Fluviphylacini), and the African lamp-eyed killifishes (Procatopodini), and (3) the Poeciliinae. He also resurrected the tribe Alfarini and proposed a new tribe, the Priapellini for Priapella.

Cnesterodontini. The tribe Cnesterodontini as originally erected by Hubbs (1924) was composed of genera Phalloceros, Cnesterodon, Phallotorynus, and Diphyacantha Henn. The Cnesterodontins were defined as poeciliines bearing "terminal segment of ray 3 forming a more or less specialized process" (Hubbs, 1924: 9). Hubbs (1926) added Darienichthys to the Cnesterodontini. Later, Rosen \& Bailey (1963) recognized Diphyacantha and Darienichthys as junior synonyms of Priapichthtys and removed them from the Cnesterodontini, placing it in the tribe Heterandriini. Rosen \& Bailey (1963) also added Phalloptychus to the Cnesterodontini. More recently, Ghedotti (2000) based on his phylogenetic study of the Poeciloidea recognized Tomeurus as a member of the tribe
Cnesterodontini and provided a diagnosis for the group anchored in unique and unreversed synapomorphies. Thus, as currently defined the Cnesterodontini comprises five genera: Cnesterodon, Phalloceros, Phallotorynus, Phalloptychus, and Tomeurus.

Cnesterodontines are disappointingly ill-studied from the perspective of systematics. Except for Cnesterodon, this group of fishes has received very little attention. The history of the genus Cnesterodon began with Jenyns' (1842) description of Poecilia decemmaculata Jenyns, the first described species currently placed in the genus. The genus Cnesterodon was erected by Garman, with Poecilia decemmaculata as typespecies, for it differed from the remaining genera so far assigned to Poeciliinae: Garman in the same paper also described a second species for the genus: C. scalpridens Garman. A third nominal species, $C$. carnegiei Haseman was described from the rio Iguaçu drainage. Regan (1913) removed $C$. scalpridens from Cnesterodon and erected the genus Pamphoria [= Pamphorichthys] for this species. Rosa \& Costa (1993) recognized the validity of $C$. decemmaculatus and $C$. carnegiei, and described C. brevirostratus Rosa \& Costa from the upper rio Uruguay and rio Jacuí drainages, and $C$. septentrionalis Rosa \& Costa from the rio Araguaia drainage. Rosa \& Costa (1993) also reported nine putative synapomorphies for the genus. Latter, Lucinda \& Garavello (2001) described C. hypselurus Lucinda \& Garavello from the rio Paranapanema basin, and C. omorgmatos Lucinda \& Garavello, a second species from the rio Iguaçu basin. Cnesterodon raddai Meyer \& Etzel was described from the lower portions of rio Paraná.

Studies concerning Phallotorynus species are notably scarce, and are mostly confined to original descriptions. Henn (1916) erected the genus Phallotorynus, based on gonopodium structure, for his new species, P. fasciolatus Henn, from the rio Paraíba do Sul. Later, Ihering (1930) described $P$. jucundus Ihering from a tributary of rio Mogi-Guaçu in the upper rio Paraná drainage. Rosen \& Bailey (1963) redefined the genus by osteological characters on the basis of specimens of $P$. fasciolatus and specimens from the neighborhood of Asunción, expanding the distribution range for $P$. jucundus to the Paraguay drainage. Finally, Oliveros (1983) described $P$. victoriae Oliveros from the lower portions of rio Paraná basin in Argentina.

Papers concerning Phalloptychus are also extremely rare in systematic literature, being confined to original descriptions. The history of Phalloptychus began with the first described species currently in the genus: Girardinus januarius Hensel. A second species, G. iheringii Boulenger was described from Rio Grande do Sul. Eigenmann (1907) created the genus Phalloptychus for Girardinus januarius. Henn (1916) described a third species, P. eigenmanni, from the rio Catu at Alagoinhas, Bahia.

Phalloceros and Tomeurus are monotypic genera and disappointingly ill-studied from the perspective of systematics. Both genera were erected by Eigenmann (1907 and 1909, respectively) for Girardinus caudimaculatus Hensel and Tomeurus gracilis, respectively. 


\section{Material and Methods}

Material examined is listed in the Appendix I. Museum acronyms are from Leviton et al. (1985), and Leviton \& Gibbs (1988) except for MNHCI: Museu de História Natural do Capão da Imbúia, Curitiba; UFPB: Universidade Federal da Paraíba, Departamento de Sistemática e Ecologia, João Pessoa; and ZVC-P: Sección Vertebrados, Facultad de Ciencias, Montevideo.

Clearing and staining followed the method of Taylor \& Van Dyke (1985). Anatomical illustrations were prepared from sketches of structures from cleared and stained specimens as viewed through a camera lucida mounted on a dissecting stereomicroscope. External characters, e.g. color pattern, were also examined.

The current definition of Poeciliinae is Parenti's (1981) definition, which corresponds to the Rosen \& Bailey's (1963) family Poeciliidae. Number and disposition of cephalic pores follow the nomenclature of Rosen \& Mendelson (1960), Gosline (1949) and Parenti (1981). Only adult individuals have been examined to avoid undesired ontogenetic variation. Nomenclature of the gonopodium followed Rosen \& Gordon (1953). Anal-fin radial terminology followed Rosen \& Kallman (1959). Descriptions of gonopodium morphology are based on fully developed gonopodia of large adult males. Anatomical nomenclature, other than gonopodial, follows Rosen \& Bailey (1963), Parenti (1981), and Rauchenberger (1989).

Proposed hypotheses of phylogenetic relationships among studied taxa followed the phylogenetic method formally put forward by Hennig (1966). The ingroup included representatives of all poeciliine genera, and all species of the tribe Cnesterodontini sensu Rosen \& Bailey (1963). The data matrix of 71 taxa and 144 characters (Appendix II) includes 24 new species of Cnesterodontini, whose descriptions will be provided by Lucinda (in prep.) and Lucinda $e t$ $a l$. (in prep.). Intrageneric relationships and synapomorphy lists for subclades of Phalloptychus, Cnesterodon, Phalloceros, and Phallotorynus are provided herein, but are discussed in Lucinda (in prep.) and Lucinda et al. (in prep.). Question marks were used to indicate when a character state could not be checked due to lacking of available specimens. Dashes were employed for both inapplicable coding and polymorphisms. The phylogenetic analysis aimed to test the monophyly of the subfamily Poeciliinae as well and its tribes (sensu Rosen \& Bailey, 1963). Fundulus heteroclitus (Linnaeus), Cyprinodon macularius Baird \& Girard, Jenynsia unitaenia Ghedotti \& Weitzman, Aplocheilichthys spilauchen (Duméril), Fluviphylax pygmaeus (Myers \& Carvalho), and Procatopus gracilis Clausen were included as outgroup taxa. Phylogenetic analyses included all 71 taxa simultaneously and were performed with Hennig86 (Farris, 1988) coupled with Tree Gardener (Ramos, 1997). Examination of more specimens suggested that there were problems with homology concerning some characters of Ghedotti's (2000) analysis (e.g. fusion of the dorsal-most proximal pectoral radial to the scapula) or these characters states could not be confirmed on existing specimens. Therefore these characters were excluded from the analysis.

All transformation series were considered unordered. Maximum parsimony analyses were undertaken using the $\mathrm{mh}^{*}$; bb* algorithm of Hennig86. Character optimization followed accelerated transformation model (ACCTRAN) for it is more consistent with the concepts of homology and synapomorphy (de Pinna, 1991). The numbers on the branches of the strict consensus tree (Fig. 1, 2, and 3) corresponds to tree nodes and to clade number. In the diagnoses and synapomorphy list uniquely derived and unreversed features are indicated by two asterisks (e.g. 47-2**); uniquely derived features are indicated by one asterisk (e.g. 24-1*). An asterisk indicates uniquely derived autapomorphies. Transformation series analysis (TSA) is presented in Appendix III. Fits of individual characters are shown in Appendix IV.

\section{Results}

\section{Character Description and Analysis}

\section{Neurocranium}

Character 0 - Mesethmoid: (0) ossified; (1) cartilaginous.

Most cyprinodontoids and other atherinomorphs possess a bony mesethmoid (state 0). Parenti (1981) discussed cartilaginous mesethmoid (state 1) as diagnostic of the subfamily Aplocheilichthyinae, including Aplocheilichthys spilauchen. However, Ghedotti (2000) verified that $A$. spilauchen have an ossified mesethmoid, which has been confirmed in this study. Costa (1998) reported a cartilaginous mesethmoid for Lebias (Cyprinodontidae) and for most procatopodines. Ghedotti (2000) reported a cartilaginous mesethmoid as diagnostic for the tribe Procatopodini. Priapella is unique among poeciliines by the possession of a cartilaginous mesethmoid.

Character 1 - Anterior margin of frontals (Ghedotti, 2000: fig. $3)$ : (0) extending anteriorly between nasals; (1) straight or slightly cleft medially.

The anterior margin of the frontals extends anteriorly by between nasals (state 0) in most Poecilioidea. Among material examined, Fluviphylax, Procatopus, Alfaro, Priapichthys, Priapella, and Belonesox possess the anterior margin of frontals straight or slightly cleft medially (state 1).

Character 2 - Parietals (Ghedotti, 2000: fig. 3): (0) large reaching sphenotic anteriorly; (1) short restrict to epiotic region, not reaching sphenotic anteriorly; (2) absent.

Parietals are present and large reaching sphenotic anteriorly (state 0 ) in atherinomorphs except for beloniforms and some cyprinodontoids (Parenti, 1981; Dyer \& Chernoff, 1996). Among the studied taxa, the following possess large parietals reaching sphenotic anteriorly: Jenynsia, Fundulus, Cyprinodon, Alfaro, Brachyrhaphis, Priapichthys, Priapella, Heterandria, Gambusia, Belonesox, Neoheterandria, Scolichthys, Girardinus, and Xiphophorus. 


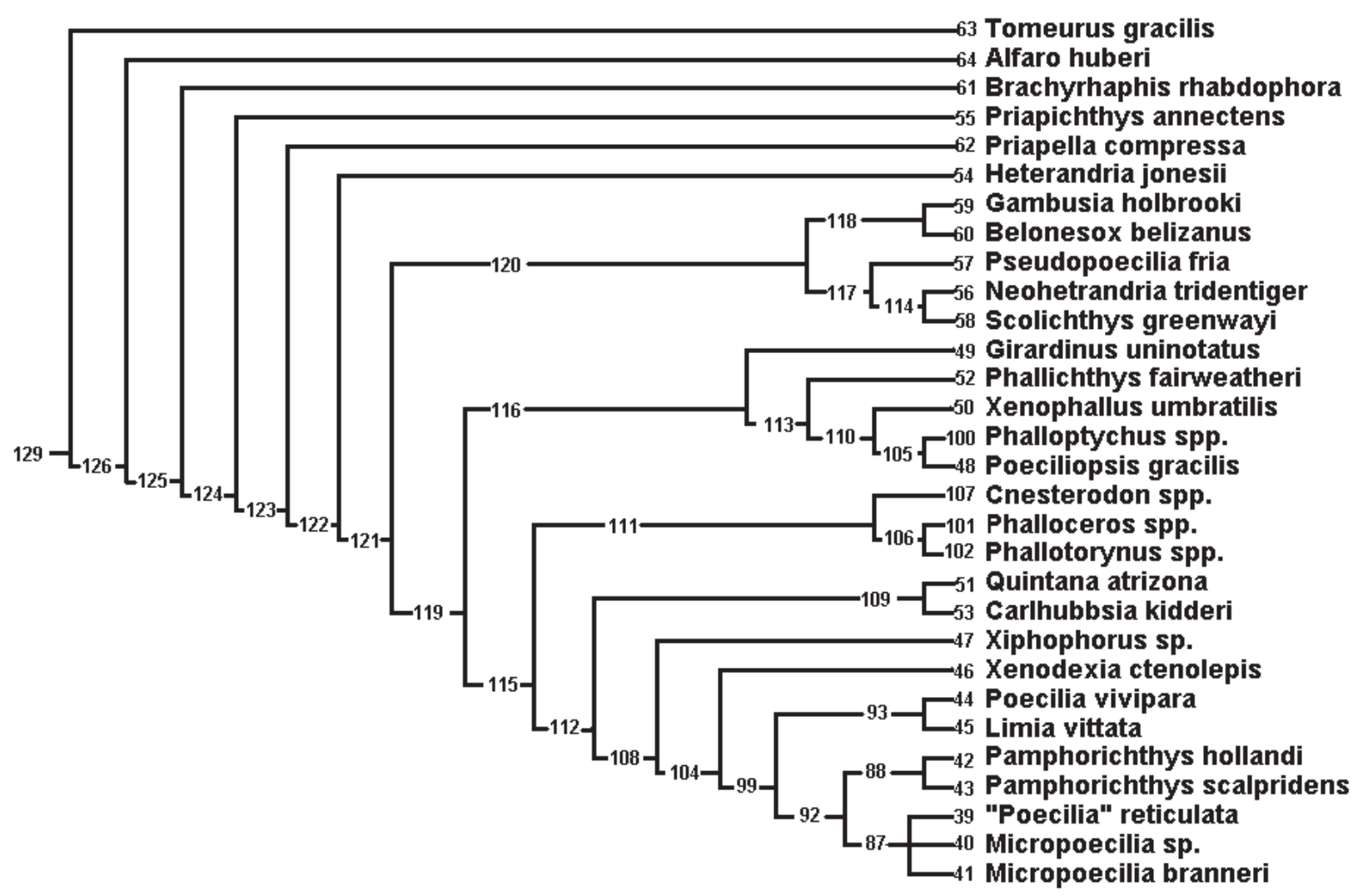

Fig. 1. Strict consensus tree of 96 most equally parsimonious trees representing a hypothesis of intergeneric relationships of Poeciliinae. Intrageneric relationships of Cnesterodon, Phallotorynus, Phalloceros, and Phalloptychus are not depicted. Character state transformations are based on ACCTRAN optimization. The numbers on the branches refer to the character state transformation series listed in the Appendix II.

According to Ghedotti (2000) parietals are present but reduced in size (state 1) in Hypsopanchax Myers, Tomeurus, Phalloceros, Poecilia, Girardinus, and Phallichthys.

Parenti (1981) reported the absence of parietals (state 2) as synapomorphic for all cyprinodontines and for Fluviphylax, Pantanodon Myers, and the procatopodines. Parietals are also independently lacking in some groups of poeciliines. Ghedotti (2000) recognized the lacking of parietals in Aplocheilichthys, Cnesterodon, Poeciliopsis, procatopodines (except Hypsopanchax) and in some individuals of Phallotorynus victoriae (polymorphic condition). Additionally, this condition was found to occur also in Pseudopoecilia, Phalloptychus, Xenodexia, Pamphorichthys, Micropoecilia, "Poecilia" reticulata Peters and Phallotorynus.

Parietals vary considerably among poeciliines (Rauchenberger, 1989; Figueiredo, 1997). Following our hypothesis, reduction and lacking of parietals appeared independently several times. Among poeciliines parietal reduction appeared independently four times: in Tomeurus [Clade 63]; Phallichthys + Xenophallus + Poeciliopsis + Phalloptychus [Clade 113]; Quintana + Carlhubbsia [Clade 109]; Poecilia + Limia [Clade 93]. The loss of parietals occurred twice: (1) in Phalloptychus and (2) in the Poeciliini + Cnesterodontini [Clade 115] with reversals to [2-1] in Quintana + Carlhubbsia [Clade 109], Poecilia + Limia [Clade 93], and in Phalloceros. A reversal to condition [2-0] occurs in Xiphophorus.

Character 3 - Epiotic process (Ghedotti, 2000: fig. 3): (0) long extending beyond first pleural rib; (1) long, longer than exoccipital process but not reaching first pleural rib; (2) short, shorter than exoccipital process; (3) absent.

Long epiotic process extending beyond first pleural rib is present in Fundulus, Jenynsia, and Aplocheilichthys and is hypothesized as plesiomorphic (state 0). Among poeciliines, enlarged epiotic processes are present in Alfaro, Phallichthys, Xenophallus, Poeciliopsis, Quintana, and Carlhubbsia.

Parenti (1981) hypothesized enlarged epiotic processes as a synapomorphy for anablepids. However, Ghedotti (1998) did not recognize expanded epiotic processes as uniquely synapomorphic of the Anablepidae and recorded their presence in Anableps, Oxyzygonectes Fowler, three species of Jenynsia, and Aplocheilichthys spilauchen. Ghedotti (2000) also observed the presence of long epiotic processes in Fundulus chrysotus Günther as well as in some poeciliines.

Girardinus and Poecilia possess an epiotic process longer than exoccipital process but not reaching first pleural rib (state 1). This condition is also observed in Brachyrhaphis, Priapichthys, Neoheterandria, Scolichthys, Girardinus, Xiphophorus, Poecilia, and Limia. 


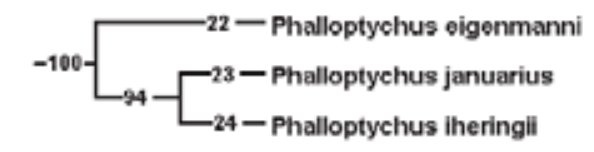

a

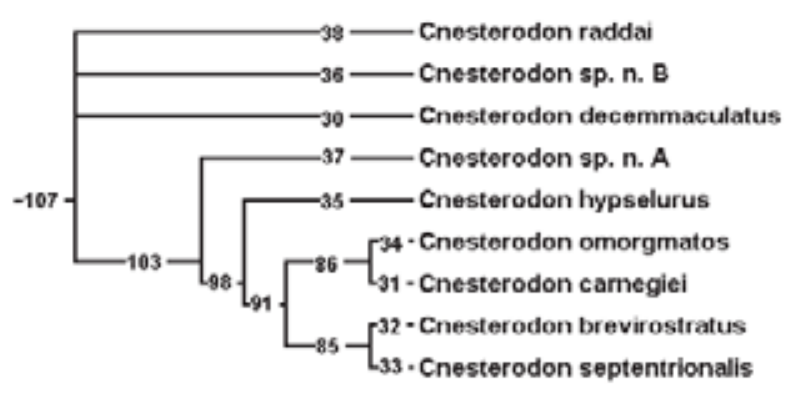

b

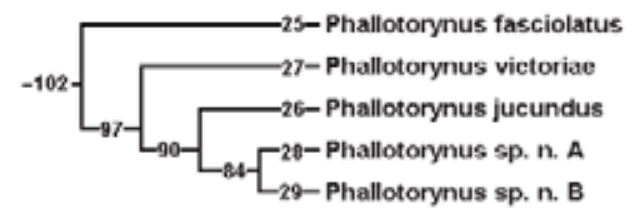

$\mathrm{c}$

Fig. 2. (a) Hypothesis of relationships among the species of Phalloptychus; (b) Hypothesis of relationships of among the species of Cnesterodon; (c) Hypothesis of relationships of among the species of Phallotorynus. Cladograms a, b, and c are a continuation of that shown in Fig. 1.

Epiotic process is shorter than exoccipital process (state 2) in Heterandria, Pseudopoecilia, Xenodexia, and "Poecilia" reticulata.

Ghedotti (2000) reported the absence of epiotic processes in procatopodines, Tomeurus, Cnesterodon, Phallotorynus, Cubanichthys Hubbs, Cyprinodon, Valencia Myers, and Crenichthys Hubbs, which is corroborated by this study. The absence of epiotic processes was also observed in Priapella, Phalloptychus, Pamphorichthys, and Micropoecilia.

Following the hypothesis presented here state [3-1] appeared once among poeciliines: in the ancestor of members of Clade 125. Condition [3-2] appeared independently four times in Heterandria, Pseudopoecilia, Xenodexia, and "Poecilia" reticulata, whereas the loss of epiotic processes occurred independently in Tomeurus, Priapella, Phalloptychus, in the ancestor of Clade 92, and in cnesterodontines.

Character 4 - Halves of supraoccipital process (Fig. 4a, b, c): (0) simple; (1) bifid, outer half minute; (2) bifid, outer half larger.

In most cyprinodontiforms halves of supraoccipital process are simple (state 0; Fig. 4a). Girardinus and Pamphorichthys possess bifid halves of supraoccipital process with a minute external half (state 1; Fig. 4b), which is interpreted as independently acquired. Cnesterodontines possess bifid halves of supraoccipital process with a large external half (state 2; Fig. 4c). A reversal to state 0 occurs in Phallotorynus fasciolatus.

\section{Cephalic sensory system}

Nomenclature follows Gosline (1949) and Rosen \& Mendelson (1960). We refer the reader to figures depicted in Gosline (1949) and Rosen \& Mendelson (1960) and in the articles cited below for a detailed comprehension of characters 5 to 10 .

Character 5 - Posterior supraorbital canal (pores 2b, 3, 4a): (0) absent or opened, forming a shallow groove (Rosen \& Mendelson, 1960: fig. 3B, J-M); (1) opened, forming a sinuous depression over the frontal (supraorbital bone) (Rosen, 1952: fig. 7); (2) closed (Gosline, 1949: plate II, fig. 1, 4; Rosen \& Mendelson, 1961: figs. 3A, C-D, F-I).

Posterior supraorbital canal varies among outgroup members and among members of the ingroup. In Aplocheilichthys, Fluviphylax, and poeciliines, except Alfaro, Brachyrhaphis, Priapichthys, Priapella, Girardinus, Carlhubbsia, Poecilia, and Limia, posterior supraorbital canal is lacking or is opened, forming a shallow groove (state 0 ). Posterior supraorbital canal form a sinuous depression over the frontal (state 1) in Procatopus, Alfaro, Brachyrhaphis, Priapichthys, and Priapella. Posterior supraorbital canal is closed (state 2) in Jenynsia, Cyprinodon, Fundulus, Girardinus, Carlhubbsia, Poecilia, and Limia.

Following the hypothesis proposed here, a sinuous depression over the frontal formed by posterior supraorbital canal (state 1) is synapomorphic for poeciliines except Tomeurus [clade 126] and was independently acquired by Procatopus. State 0 is interpreted as a synapomorphic reversal for Heterandriini + Gambusiini + Supertribe Poeciliini [Clade 122]; whereas a closed posterior supraorbital canal (state 2) appeared independently three times in Girardinus, Carlhubbsia, and in Poecilia + Limia [clade 93].

Character 6 - Anterior section of posterior remnant of infraorbital system (pores 4b, 5, 6a): (0) absent or opened, forming a shallow groove (Rosen \& Mendelson, 1960: fig. 3A-E, G-P); (1) opened, pores confluent forming a major sinuous depression above and slightly behind the orbit (Rosen, 1952: fig. 7); (2) closed (Gosline, 1949: plate II, fig. 1, 4; Rosen \& Mendelson, 1960: fig. 3F).

Posterior supraorbital canal varies among members of the outgroup and among members of the ingroup. In Aplocheilichthys, Fluviphylax, and poeciliines, except Alfaro, Brachyrhaphis, Priapichthys, and Priapella, anterior section of posterior remnant of infraorbital system is lacking or is opened, forming a shallow groove (state 0 ). Anterior section of posterior remnant of infraorbital system forms a major sinuous depression above and slightly behind the orbit (state 1) in Procatopus, Alfaro, Brachyrhaphis, Priapichthys, and Priapella. Anterior section of posterior remnant of infraorbital system is closed (state 2) in Jenynsia, Cyprinodon, and Fundulus. 


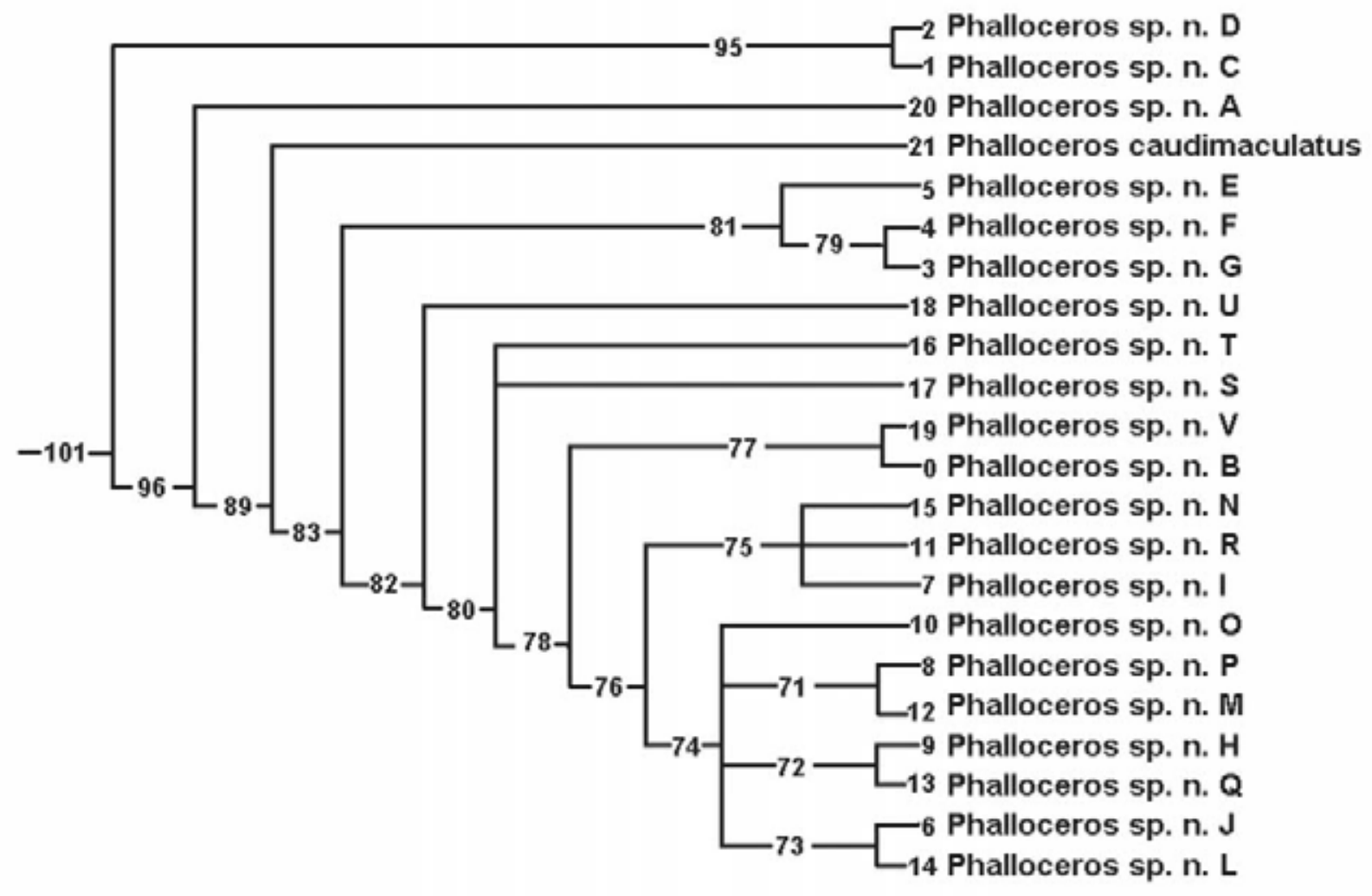

Fig. 3. Hypothesis of relationships of among the species of Phalloceros. Cladogram is a continuation of that shown in Fig. 1.

Following the hypothesis proposed here, a major sinuous depression above and slightly behind the orbit formed by anterior section of posterior remnant of infraorbital system (state 1) is synapomorphic for poeciliines except Tomeurus [clade 126] and was independently acquired by Procatopus. State 0 is interpreted as a synapomorphic reversal for Heterandriini + Gambusiini + Supertribe Poeciliini [Clade 122]. Within supertribe Poeciliini a change to state 1 occurs in Carlhubbsia.

Character 7 - Posterior section of posterior remnant of infraorbital system (canal 6b, 7): (0) closed (Gosline, 1949: plate II, fig. 4; Parenti, 1981: fig. 14A; Ghedotti \& Weitzman, 1995: fig. 2); (1) opened into a groove (Rosen \& Mendelson, 1960: fig. 2A, B).

Most cyprinodontiforms possess a closed posterior section of posterior remnant of infraorbital system (state 0). Posterior section of posterior remnant of infraorbital system opened into a groove (state 1) is herein hypothesized as apomorphic and to have been independently acquired by Tomeurus, Gambusia + Belonesox [clade 118], Scolichthys, Phalloptychus, Pamphorichthys, and cnesterodontines (with a reversal in Phallotorynus).

Character 8 - Preopercular canal: (0) present and entirely closed, except for seven pores $(8,9,10,11,12, \mathrm{U}, \mathrm{V})$ (Gosline, 1949: plate II, fig. 2); (1) absent or opened in a shallow groove (Rosen \& Mendelson, 1960: fig. 2A, B); (2) present and entirely closed, except for four pores $(8,11,12, \mathrm{~V})$; (3) present and partially closed, only canal between pores $\mathrm{U}$ - V closed;
(4) present and partially closed, only canals between pores 11-12, and 12-U closed (sometimes canal U-V also closed); (5) present and partially closed: canal 8, 9, 10 opened in a deep groove; pore 11 opened and elongate (sometimes confluent with groove $8,9,10$ ) canal between pores $12, \mathrm{U}-\mathrm{V}$ closed (sometimes canal U-V opened); (6) restrict to closed canal 10-11.

All studied outgroup taxa (except Fluviphylax) possess a closed preopercular canal, except for seven pores $(8,9,10$, 11,12, U, V) (state 0). In Belonesox, Scolichthys, Pamphorichthys, and Cnesterodon preopercular canal is lacking or opened in a shallow groove (state 1). Phallotorynus species share a closed preopercular, except for four pores $(8$, 11,12, V) (state 2). Gambusia presents a partially closed preopercular canal, with canal only between pores $\mathrm{U}-\mathrm{V}$ closed (state 3). In Tomeurus, preopercular canal is present and partially closed, with canals only between pores 11-12, and 12-U closed (sometimes canal U-V also closed) (state 4). In Phalloceros, the preopercular canal is partially closed: canal between pores $8,9,10$ opened in a deep groove; pore 11 opened and elongate (sometimes confluent with groove 8, 9, 10 ); canal between pores $12, \mathrm{U}-\mathrm{V}$ closed (state 5). Finally, preopercular canal is restricted to closed canal 10-11 in Fluviphylax (state 6).

Following our hypothetical history of poeciliines, state 1 appeared independently in Belonesox, Scolichthys, Pamphorichthys, and Cnesterodon, whereas states 2, 3, 4, 5, and 6 are interpreted as synapomorphic for Phallotorynus, Gambusia, Tomeurus Phalloceros, and Fluviphylax, respectively. 


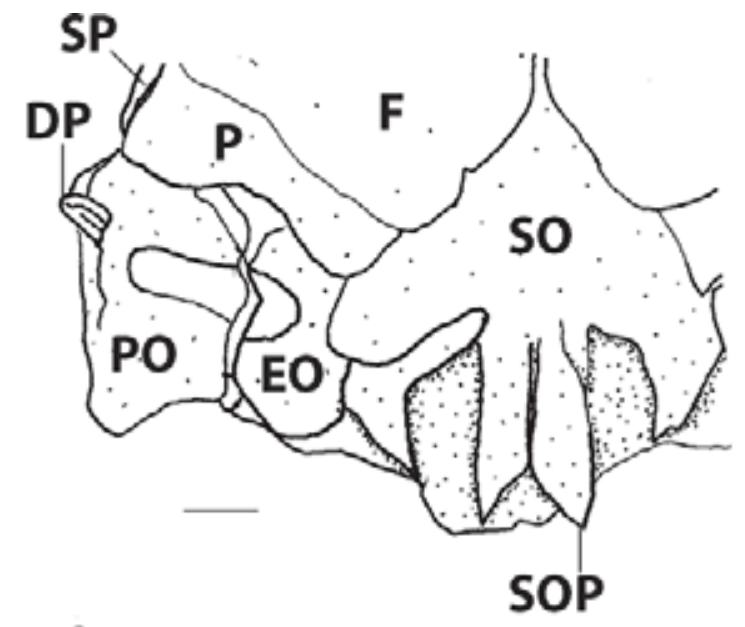

a
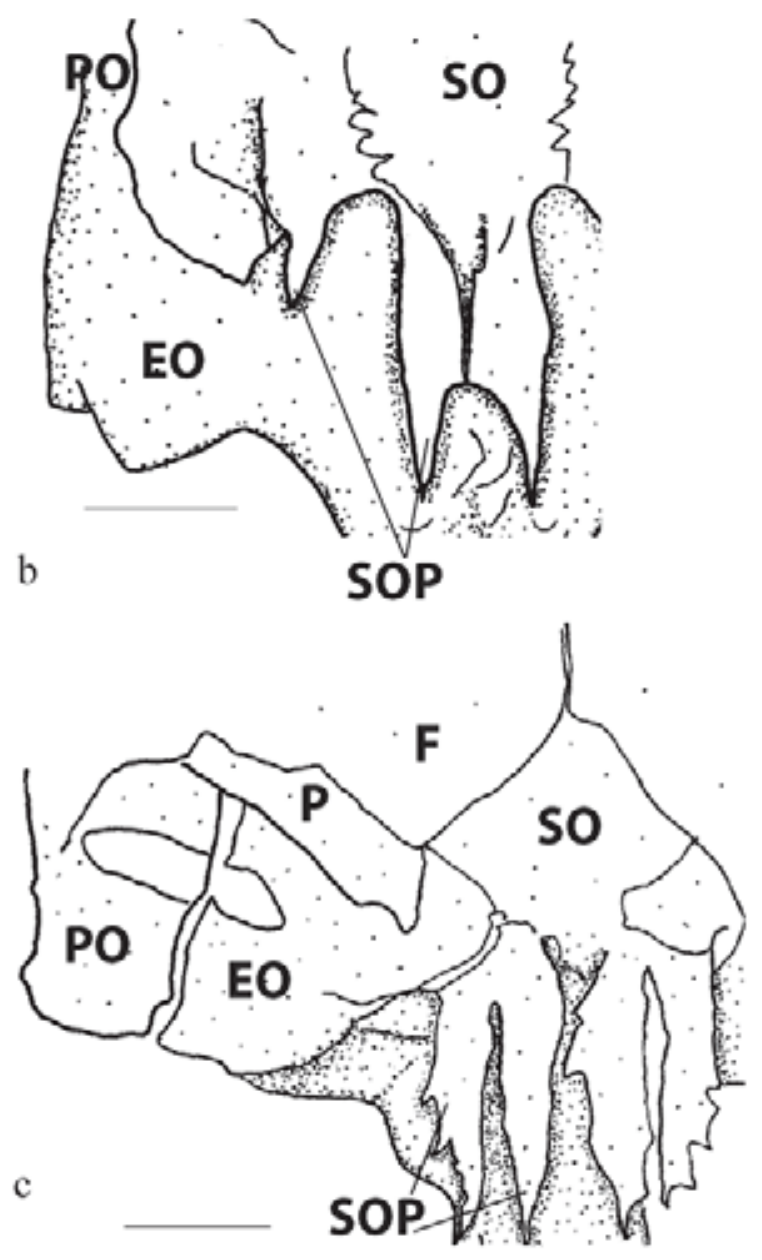

Fig. 4. Dorsal view of posterior crania. (a) Heterandria jonesii, UMMZ 210999; (b) Girardinus uninotatus, AMNH 96301; (c) Phalloceros n. sp. G, MCP 30509. DP = dermosphenotic; EO = epiotic $; \mathrm{F}=$ Frontal $; \mathrm{P}=$ parietal $; \mathrm{PO}=$ pterotic $; \mathrm{SO}=$ supraoccipital; $\mathrm{SOP}=$ supraoccipital process; $\mathrm{SP}=$ sphenotic. Scale bar $1 \mathrm{~mm}$.

Character 9 - Preorbital canal: (0) present and entirely closed, bearing four pores (Rosen \& Mendelson, 1960: fig. 2C, D); (1) present and partially closed bearing two upper pores and a lower deep groove; (2) absent or opened, forming a very shallow groove (Rosen \& Mendelson, 1960: fig. 2C, D); (3) present and entirely closed, bearing three pores.

Among studied taxa, preorbital canal is entirely closed; bearing four pores (state 0) in Aplocheilichthys, Procatopus, Jenynsia, Fundulus, Alfaro, Priapella, Girardinus, Xenophallus, Xenodexia, Poecilia, and Limia. Preorbital canal is partially closed bearing two upper pores and a lower deep groove (state 1) in Brachyrhaphis, Priapichthys, Heterandria, Phallichthys, Poeciliopsis, Quintana, Carlhubbsia, Xiphophorus, "Poecilia", and Micropoecilia. In Tomeurus, gambusiines, Phalloptychus, Pamphorichthys and cnesterodontines preorbital canal is absent or opened, forming a very shallow groove (state 2). Cyprinodon presents preorbital canal closed, bearing three pores. State 1 is hypothesized to has independently appeared twice: (1) as a synapomorphy for poeciliines except Tomeurus and Alfaro [Clade 125] (with several subsequent reversals); (2) as a synapomorphy for Micropoecilia + "Poecilia" [Clade 87]. Additionally, state 2 is interpreted as independently evolved in Fluviphylax, Tomeurus, gambusiines, Phalloptychus, Pamphorichthys, and cnesterodontines.

Character 10 - Mandibular canal (W, X, Y, Z): (0) present and entirely closed, bearing four pores (Gosline, 1949: plate II, fig. 3, 5, 6; Ghedotti \& Weitzman, 1995: fig. 3); (1) absent or opened, forming a very shallow groove; (2) present and entirely closed, bearing five pores; (3) present and partially closed bearing six pores; (4) present and partially closed; canal connecting pores X and $\mathrm{W}$ closed; canal connecting pores $\mathrm{Y}$ and $\mathrm{Z}$ absent; (5) present and entirely closed, bearing three pores, pore $\mathrm{Z}$ absent; (6) opened, formed by two deep grooves.

Among studied taxa, mandibular canal is entirely closed; bearing four pores (state 0) in Aplocheilichthys, Jenynsia, Cyprinodon, and Fundulus. Mandibular canal is absent or opened, forming a very shallow groove (state 1) in Fluviphylax, Tomeurus, and members of the supertribe Poeciliini with the exception of Girardinus, Xenodexia, and Poecilia. This condition is hypothesized to have been independently acquired in these groups. Procatopus and Priapella possess a mandibular canal entirely closed, bearing five pores (state 2) and the presence of this feature in these taxa is interpreted as homoplastic. Mandibular canal is partially closed bearing six pores (state 3) in Priapichthys. Mandibular canal is present and partially closed; canal connecting pores $\mathrm{X}$ and $\mathrm{W}$ closed; canal connecting pores $\mathrm{Y}$ and Z absent (state 4) in Gambusia. Mandibular canal is entirely closed bearing three pores, pore Z absent (state 5) in Girardinus. Mandibular canal is opened, formed by two deep grooves in Xenodexia (state 6). States 3, 4, 5, and 6 are interpreted as autapomorphic for Priapichthys, Gambusia, Girardinus, and Xenodexia, respectively.

\section{Suspensorium and mandibular arch}

Character 11 - Medial surface of ascending process of premaxilla (Ghedotti, 2000: fig. 3): (0) approximately straight; (1) slightly angled laterally; (2) angled laterally at proximal end, forming a triangle space between proximal ends of ascending processes. 

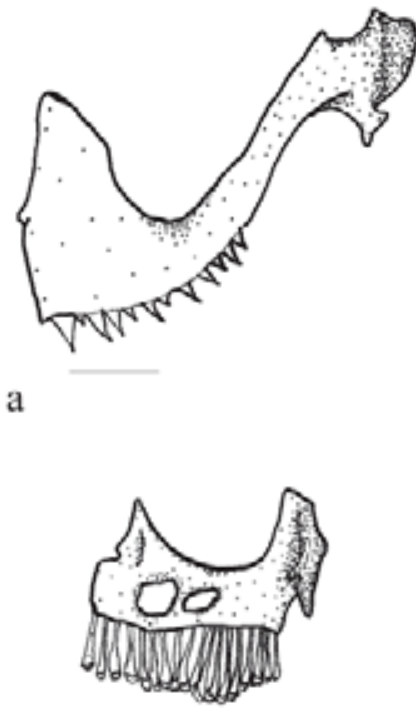

$\mathrm{c}$

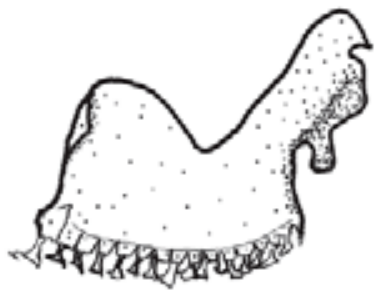

$\mathrm{e}$

Fig. 5. Dorsal view of left premaxilla. (a) Heterandria jonesii, UMMZ 210999; (b) Priapichthys annectens, ANSP 163139; (c) Phalloptychus iheringii, MCP 11054; (d) Phalloceros n. sp. G, MCP 30509; (e) Girardinus uninotatus, AMNH 96301; (f) Cnesterodon n. sp. B, MCP 19784. Scale bar $1 \mathrm{~mm}$.

Ghedotti (2000) reported a laterally angled medial surface of the ascending processes as independently acquired by Micropanchax and the common ancestor of a clade composed of Cnesterodon, Phalloceros, Phallotorynus, Girardinus, Poecilia, Phallichthys, and Tomeurus with a reversal in Tomeurus. Ghedotti (2000) recognized only two character states whereas this study recognizes a third intermediate state (state 1).

Medial surface of ascending process of premaxilla is approximately straight (state 0) in all studied outgroup taxa and Scolichthys, Neoheterandria, Pseudopoecilia, Cnesterodon n. sp. A, C. hypselurus, C. brevirostratus, $C$. septentrionalis, and Phallotorynus fasciolatus. Alfaro, Brachyrhaphis, Priapichthys, Priapella, and Heterandria possess a slightly laterally angled medial surface (state 1). Medial surface of ascending process of premaxilla is laterally angled at proximal end, forming a triangular space between proximal ends of ascending processes (state 2 ) in the remaining studied taxa.

Our phylogenetic hypothesis indicates that a slightly laterally angled medial surface of ascending process of premaxilla (state 1) is uniquely derived for a clade embracing all poeciliines but Tomeurus [Clade 126]. State 2 appears to be synapomorphic for Tribe Gambusiini + Supertribe Poeciliini [Clade 121], and it shows three subsequent reversals to state 0: (1) in the common and exclusive ancestor of Scolichthys, Neoheterandria, and Pseudopoecilia [Clade 117]; (2) in the common and exclusive ancestor of Cnesterodon n. sp. A, $C$. hypselurus, C. brevirostratus, C. septentrionalis [Clade 103], and in Phallotorynus fasciolatus.

Character 12 - Shape of the ascending process of premaxilla (Fig. 5a-f): (0) Elongate, distal tip rounded; (1) elongate, distal tip pointed; (2) short and pointed; (3) short and truncate; (4) short, distal tip rounded; (5) minute, almost absent.

Ascending process of premaxilla is elongate with a round distal tip (state 0; Fig. 5a) in Aplocheilichthys, Jenynsia, Fluviphylax, Procatopus, Tomeurus, Alfaro, Brachyrhaphis, Priapella, Heterandria, and Pseudopoecilia. Cyprinodon, Fundulus, Priapichthys, Gambusia, Neoheterandria, and Scolichthys possess an elongate ascending process of premaxilla, with a pointed distal tip (state 1; Fig. 5b). Remaining poeciliines except Girardinus, Quintana, Phalloceros, and Cnesterodon $\mathrm{n}$. sp. B have a short and pointed ascending process of premaxilla (state 2; Fig. 5c). Quintana and Phalloceros have a short and truncate ascending process of premaxilla (state 3; Fig. 5d). Girardinus presents the ascending process of premaxilla short with distal tip round (state 4; Fig. 5e), whereas Cnesterodon n. sp. B has a minute ascending process of premaxilla (state 5; Fig. 5f).

An elongate ascending process of premaxilla, with a pointed distal tip (state 1; Fig. 5b) is hypothesized as synapomorphic and independently acquired in the Priapichthyini and the Gambusiini (with a reversal to state 0 in Pseudopoecilia). A short and pointed ascending process of premaxilla (state 2; Fig. 5c) is interpreted as a uniquely derived and unreversed synapomorphy for the supertribe Poeciliini [Clade 119], with subsequent transformations to states 3 (Quintana and Phalloceros), 4 (Girardinus), and 5 (Cnesterodon n. sp. B).

Character 13 - Contact area between premaxillae: (0) not elevate; (1) elevate.

The contact area between premaxillae is plain in almost all cyprinodontoids (state 0 ). An elevated contact area between premaxillae (state 1) is hypothesized as a synapomorphy for the members of the supertribe Poeciliini, with a reversal to the plesiomorphic condition in the Phallotorynus + Phalloceros [Clade 106].

Character 14 - Anterior border of ventral maxilla (Fig. 6a, B): (0) straight; (1) concave.

The anterior border of ventral maxilla is straight (state 0; Fig. 6a) in outgroup taxa, as well as in Priapella, Gambusia, Belonesox, Neoheterandria, and Scolichthys and all members of the supertribe Poeciliini with the exception of Girardinus. Anterior border of ventral maxilla is concave (state 1; Fig. 6b) in Alfaro, Brachyrhaphis, Priapichthys, 
Heterandria, Pseudopoecilia, and Girardinus and is interpreted as synapomorphic for Clade 126, which comprises all poeciliines but Tomeurus. A reversal to state 0 occurs in Priapellini and in the common and exclusive ancestor of members of Clade 121 [Gambusiini + Supertribe Poeciliini]. Within this clade a transformation 0 to 1 appears in Pseudopoecilia and Girardinus.

Character 15 - Ventral surface of dentary (Costa, 1991: fig. 4G, 5E and Ghedotti, 2000: fig. 5): (0) straight or bearing a tiny straight process; (1) bearing a curved and forward directed process.

Most cyprinodontiforms possess the ventral surface of dentary straight or bearing a tiny straight process (state 0). Costa (1991) suggested the presence of a curved and forward directed process on ventral surface of dentary (state 1) as a putative synapomorphy for a group embracing Pamphorichthys, Poecilia, Limia, Xiphophorus, Cnesterodon, Phalloceros, Phallotorynus, Phalloptychus, Priapichthys, Poeciliopsis, Priapella, Quintana, Carlhubbsia, Xenodexia, and Phallichthys. This is partially corroborated by our results. The current phylogenetic analysis supports this feature as a uniquely derived and unreversed synapomorphy for the supertribe Poeciliini [Clade 119]. In addition to the genera above (except Priapichthys and Priapella), this group comprises Girardinus, Xenophallus, and Micropoecilia.

Character 16 - Notch on dentary (Rosen \& Bailey, 1963: fig. 21 C, F): (0) absent; (1) present.

Most poeciliids lacks a notch on dentary (state 0). A notch on dentary is present in Phallichthys, Poeciliopsis, Carlhubbsia, Xiphophorus, Xenodexia, Poecilia, Limia, and "Poecilia" reticulata. This feature is interpreted as apomorphic (state 1) and independently acquired by Phallichthys, Poeciliopsis and by the common and exclusive ancestor of members of the tribe Poeciliini, with a reversal in Pamphorichthys + Micropoecilia + "Poecilia" (Clade 92). A return to state 1 occurs in "Poecilia" reticulata.

Character 17 - Anterior cleft of anguloarticular (Ghedotti, 2000: fig. 5): (0) small, not extending beyond posterior border of Meckel's cartilage; (1) large, extending beyond posterior border of Meckel's cartilage; (2) absent.

Anterior cleft of anguloarticular is small, not extending beyond posterior border of Meckel's cartilage (state 0) in Aplocheilichthys, Procatopus, Jenynsia, and in all poeciliines except Phalloceros. In Cyprinodon and Fundulus the anterior cleft of anguloarticular is large, extending beyond posterior border of Meckel's cartilage (state 1). Anterior cleft of anguloarticular is absent (state 2) and interpreted as synapomorphic for a clade embracing Phalloceros n. sp. S + Phalloceros n. sp. $\mathrm{T}+$ Phalloceros $\mathrm{n}$. sp. $\mathrm{V}+$ Phalloceros $\mathrm{n}$. sp. B + Phalloceros n. sp. $\mathrm{N}+$ Phalloceros n. sp. $\mathrm{R}+$ Phalloceros n. sp. I + Phalloceros n. sp. O + Phalloceros $\mathrm{n}$. sp. $\mathrm{P}+$ Phalloceros n. sp. $\mathrm{M}+$ Phalloceros n. sp. $\mathrm{H}+$ Phalloceros $\mathrm{n}$. sp. Q + Phalloceros n. sp. J + Phalloceros $\mathrm{n}$. sp. L [Clade 80], with a reversal to state 0 in (Phalloceros $\mathrm{n}$. sp. P + Phalloceros n. sp. M) Clade [71].

Character 18 - Ventral process of anguloarticular (Ghedotti, 2000: fig. 5): (0) long, extending anterior to where anguloarticular overlaps dentary; (1) short, not extending anterior to where anguloarticular overlaps dentary; (2) absent.

Parenti (1981) recognized an elongate retroarticular as synapomorphic for the superfamily Poecilioidea. Costa (1998) modified the character state description used by Parenti (1981) to recognize the co-occurrence of a long retroarticular and a long ventral process of the anguloarticular as synapomorphic of Poecilioidea. Ghedotti (2000) treated the ventral process of the anguloarticular and the retroarticular as separate transformation series because they vary independently. Ghedotti (2000) reported a long ventral process of the anguloarticular in all poecilioids examined by him.

Among studied taxa, Aplocheilichthys, Jenynsia, Procatopus and almost all poeciliines the ventral process of anguloarticular is long, extending anterior to where anguloarticular overlaps dentary (state 0 ).

This process is short, not extending anterior to where anguloarticular overlaps dentary (state 1) in Cyprinodon, Fundulus, Poeciliopsis, and Phalloptychus. State 1 is herein interpreted as synapomorphic for the clade [Poeciliopsis + Phalloptychus]. Its presence in Fundulus and Cyprinodon is considered homoplastic.

Ventral process of anguloarticular is absent (state 2) and interpreted as synapomorphic for the clade [Phalloceros $\mathrm{n} . \mathrm{sp}$. $\mathrm{S}+$ Phalloceros n. sp. $\mathrm{T}+$ Phalloceros $\mathrm{n} . \mathrm{sp} . \mathrm{V}+$ Phalloceros n. sp. B + Phalloceros n. sp. $\mathrm{N}+$ Phalloceros $\mathrm{n}$. sp. $\mathrm{R}+$ Phalloceros $\mathrm{n}$. sp. I Phalloceros $\mathrm{n}$. sp. $\mathrm{O}+$ Phalloceros $\mathrm{n}$. sp. $\mathrm{P}+$ Phalloceros n. sp. $\mathrm{M}+$ Phalloceros n. sp. $\mathrm{H}+$ Phalloceros n. sp. Q + Phalloceros n. sp. J + Phalloceros $\mathrm{n}$. sp. L] [Clade 80], with a reversal to state 0 in the ancestor of Phalloceros n. sp. P and Phalloceros n. sp. M [Clade 71].

Character 19 - Ventral invagination on anguloarticular (Fig. 7): (0) absent; (1) present.

Among studied taxa, Phalloceros n. sp. B, Phalloceros n. sp. C, and Phalloceros n. sp. V possesses a ventral invagination on anguloarticular, which is interpreted as synapomorphic for Phalloceros n. sp. C + Phalloceros n. sp. V and independently acquired in Phalloceros n. sp. B.

Character 20 - Ascending process of parasphenoids in adults (Ghedotti, 2000: fig. 3): (0) long, contacting pterosphenoids;

(1) short, not reaching pterosphenoids; (2) absent.

Among the studied taxa, in Aplocheilichthys, Procatopus, Jenynsia, Fundulus, Tomeurus, Alfaro, Brachyrhaphis, Priapella, Priapichthys, Heterandria, Belonesox, Neoheterandria, Phallichthys, Xenophallus, Poeciliopsis, Phalloptychus, Quintana, Carlhubbsia, Xiphophorus, Poecilia, Limia, Pamphorichthys hollandi Henn, Micropoecilia, "Poecilia”, Phallotorynus n. sp. A, Phallotorynus n. sp. B, and Phalloceros, the ascending process of parasphenoids in adults is long, contacting 
pterosphenoids (state 0). In remaining taxa studied except Xenodexia, this process is short, not reaching pterosphenoids (state 1). In Xenodexia, ascending process of parasphenoids is absent (state 2). Although this character contributed to the resolution of the present topology, it presented several independent acquisitions and reversals during the history of the Cyprinodontiformes.

Character 21 - External teeth: (0) conical; (1) compressed.

Tooth form has been extensively employed as the basis of classification of cyprinodontiform fishes (Günther, 1866; Garman, 1895; Regan, 1911). The phylogenetic importance of tooth form was minimized by other precladistic authors in favor of reproductive characteristics (e.g. Regan, 1913; Rosen \& Bailey, 1963). Rodriguez (1997) reported compressed teeth in outer series of premaxilla and dentary as synapomorphic for the clade Xiphophorus, Poecilia, Pamphorichthys, and Limia with a reversal in Pamphorichthys, which has subcylindrical and pointed teeth. Ghedotti (2000) reported conical teeth for Aplocheilichthys spilauchen, all procatopodines examined, Gambusia affinis, Alfaro cultratus, Tomeurus gracilis, Valencia, and Fundulus.

Among studied taxa, procatopodines, Fundulus, Tomeurus, Alfaro, Brachyrhaphis, Priapichthys, Priapella, Heterandria, Gambusia, Belonesox, Pseudopoecilia, Neoheterandria, Scolichthys, Cnesterodon brevirostratus, and $C$. septentrionalis possess firmly rooted, conical, pointed teeth (state 0 ). In remaining poeciliines studied, teeth are movable, pedunculate and flattened distally (state 1). On the basis of present hypothesis, compressed teeth is interpreted as a synapomorphy for a clade containing the genera Girardinus, Phallichthys, Xenophallus, Poeciliopsis, Phalloptychus, Quintana, Carlhubbsia, Xiphophorus, Xenodexia, Poecilia, Limia, Pamphorichthys, Micropoecilia, "Poecilia", Cnesterodon, Phallotorynus, and Phalloceros [Supertribe Poeciliini - Clade 119], with a reversal in Cnesterodon brevirostratus $+C$. septentrionalis clade.

\section{Hyoid arch}

Character 22 - Number of branchiostegal rays (Ghedotti, 2000: fig. 7): (0) five; (1) six.

This character has been discussed by Ghedotti (2000). In individuals with six branchiostegal rays, the anterior two branchiostegal rays are in contact with the slender anterior portion of the anterior ceratohyal, three branchiostegal rays are in contact with the ventromedially expanded portion of the anterior ceratohyal, and the posterior branchiostegal ray is in contact with the posterior ceratohyal (state 1). In individuals with five branchiostegal rays, one of the anterior two branchiostegal rays is absent (state 0 ). The possession of six branchiostegal rays is interpreted as a synapomorphy for poeciliines with a reversal to plesiomorphic condition in the ancestor of members of the supertribe Poeciliini [Clade 119]. Inside this clade a change to state 1 occurred independently in Xenophallus and Limia.

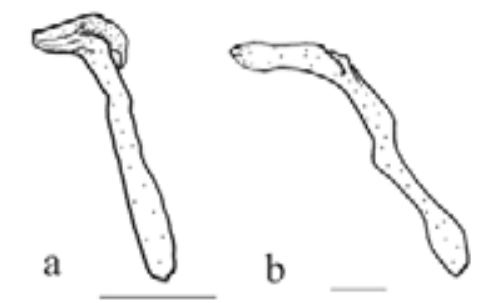

Fig. 6. Lateral view of left maxilla of (a) Alfaro huberi, UMMZ 190567; (b) Cnesterodon n. sp. B, MCP 19784. Scale bar $1 \mathrm{~mm}$.

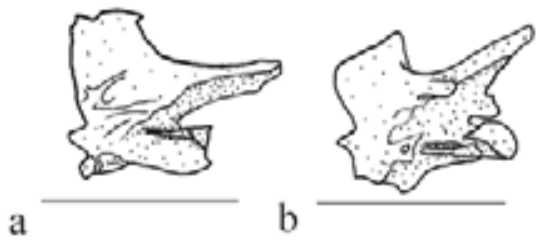

Fig. 7. Lateral view of inner surface of the anguloarticular of (a) Phalloceros n. sp. F, MCP 30572; (b) Phalloceros n. sp. C, UFPB 2214. Scale bar $1 \mathrm{~mm}$.

Character 23 - First and second branchiostegal rays: (0) free from each other; (1) united at the base.

In most atherinomorphs first and second branchiostegal rays are free from each other (state 0 ). In Neoheterandria and Scolichthys first and second branchiostegal rays are united at the base (state 1). This condition is interpreted as synapomorphic for Neoheterandria + Scolichthys [Clade 114].

Character 24 - Anterior process of anterior ceratohyal extending ventrally to ventral hypohyal (Ghedotti, 2000: fig. 8): (0) present; (1) absent.

Parenti (1981) and Costa (1998) recognized the absence of an anterior process of the anterior ceratohyal (only one condyle on the anterior ceratohyal) as synapomorphic of the Poeciliidae. The anterior process of the anterior ceratohyal was reported absent in all poeciliids examined except Aplocheilichthys spilauchen by Ghedotti (2000).

We observed this process in Aplocheilichthys, Jenynsia, Tomeurus, and Brachyrhaphis. All remaining studied taxa lack the anterior process of anterior ceratohyal extending ventral to ventral hypohyal (state 1). According to present hypothesis the absence of this process is synapomorphic for the subfamily Poeciliinae with reversals in Tomeurus, Brachyrhaphis, and Heterandria.

Character 25 - Interarcual cartilage: (0) present; (1) absent.

The interarcual cartilage is present (state 0 ) in all taxa examined, except in Tomeurus and Priapella. The absence of an interarcual cartilage (state 1) in these two taxa is interpreted as independently acquired.

\section{Branchial arches}

Character 26 - Tooth plates of third and fourth pharingobranchials (Costa, 1991: fig. 4I, 5D and Ghedotti, 2000: 
fig. 10B): (0) two separate plates with teeth irregularly distributed; (1) fused, forming an elongate structure with teeth regularly distributed.

Most cyprinodontiforms possess tooth plates of third and fourth pharingobranchials as two separate plates with teeth irregularly distributed (state 0). Costa (1991) suggested that tooth plates of third and fourth pharingobranchials fused, forming a elongate structure with teeth regularly distributed (state 1) as a putative synapomorphy for a group embracing Pamphorichthys, Poecilia, Limia, Xiphophorus, Cnesterodon, Phalloceros, Phallotorynus, Phalloptychus, Priapichthys, Poeciliopsis, Priapella, Quintana, Carlhubbsia, Xenodexia, and Phallichthys. This is partially corroborated by our results. The current phylogenetic analysis supports this feature as a uniquely derived and unreversed synapomorphy for the supertribe Poeciliini [Clade 119]. In addition to the genera above (except Priapichthys and Priapella), this group comprises Girardinus, Xenophallus, and Micropoecilia.

Character 27 - Teeth on fourth ceratobranchial (Ghedotti, 2000: fig. 9): (0) present; (1) absent.

Among studied taxa Aplocheilichthys, Procatopus, Jenynsia, Fundulus, Tomeurus, Alfaro, Brachyrhaphis, Priapella, Priapichthys, Heterandria, Gambusia, Belonesox, Pseudopoecilia, Neoheterandria, Cnesterodon n. sp. A, C. hypselurus, $C$. brevirostratus, $C$. carnegiei, $C$. omorgmatos, and Phalloceros n. sp. D exhibit teeth on fourth ceratobranchial. These are lacking in the remaining studied taxa. Global parsimony analysis demonstrate that the loss of teeth in fourth ceratobranchial is apomorphic and occurred independently in Fluviphylax, Cyprinodon, Scolichthys, and in the ancestor of members of Clade 119, with subsequent reversals in Phalloceros n. sp. D, Xiphophorus and in node 103. Within Clade 103, a $0>1$ change happened in $C$. septentrionalis.

Character 28 - Fifth ceratobranchial (Costa, 1991: fig. 4H; 5C): (0) narrow bearing teeth irregularly distributed; (1) wide bearing teeth regularly distributed.

Most cyprinodontiforms possess a narrow fifth ceratobranchial, bearing irregularly distributed teeth (state 0). Costa (1991) suggested a wide fifth ceratobranchial bearing regularly distributed teeth (state 1) as a putative synapomorphy for a group embracing Pamphorichthys, Poecilia, Limia, Xiphophorus, Cnesterodon, Phalloceros, Phallotorynus, Phalloptychus, Priapichthys, Poeciliopsis, Priapella, Quintana, Carlhubbsia, Xenodexia, and Phallichthys. This is partially corroborated by our results. The current phylogenetic analysis supports this feature as a uniquely derived and unreversed synapomorphy for the supertribe Poeciliini [Clade 119]. In addition to the genera above (except Priapichthys and Priapella), this group comprises Girardinus, Xenophallus, and Micropoecilia.

Character 29 - Anterior margin of first hypobranchial: (0) mostly straight; (1) concave forming distinct anterior point.
Anterior margin of first hypobranchial is mostly straight (state 0) in Fluviphylax, Procatopus, and Fundulus. Anterior margin of first hypobranchial is concave, forming distinct anterolateral point (state 1) in Aplocheilichthys, Jenynsia, Cyprinodon, and all poeciliines. This feature was useless for poeciliine relationships and probably is a synapomorphy for a more inclusive clade.

Ghedotti (2000) reported a concave anterior margin of first hypobranchial in Oxyzygonectes dovii, Cyprinodon variegatus, Fundulus chrysotus, and all poeciliines examined except some individuals of Tomeurus gracilis (coded as polymorphic).

Character 30 - Third basibranchial: (0) cartilaginous; (1) ossified and toothed.

Most cyprinodontiforms possess a cartilaginous toothless third basibranchial. Phalloceros n. sp. D, Phalloceros n. sp. G, Phalloceros n. sp. F, Phalloceros n. sp. U, and Phalloceros n. $\mathrm{sp}$. H are unique among poeciliines by possession of a ossified and toothed third basibranchial. This derived feature is hypothesized to have appeared independently in Phalloceros $\mathrm{n}$. sp. D, Phalloceros n. sp. U, and Phalloceros n. sp. H, and in the ancestor of Phalloceros n. sp. G and Phalloceros n. sp. F.

\section{Pectoral fin and girdle}

Character 31 - Post-temporal: (0) bifid; (1) unbranched.

Most cyprinodontiforms possess a bifid post-temporal (state 0). In Fundulus, Scolichthys, Cnesterodon, Phallotorynus, and Phalloceros the post-temporal is unbranched (state 1). According to the present hypothesis of relationships an unbranched post-temporal is assumed as apomorphic and independently acquired by Fundulus, Scolichthys, and by the ancestor of cnesterodontines.

Ghedotti (2000) reported an unbranched posttemporal in Cnesterodon, Phalloceros caudimaculatus, Phallotorynus, Valencia, Fundulus and many procatopodines.

Character 32 - Position of pectoral fins: (0) low, below midline; (1) high, at or above midline.

The position of the pectoral fins is low, with dorsal insertion below midline in most cyprinodontiforms (state 0 ). In poeciliids, the position of the pectoral fins is high, with dorsal insertion at or above midline (state 1). With the exception of Jenynsia, Fundulus, and Cyprinodon, all studied taxa present high pectoral fins. This feature probably is synapomorphic for the family Poeciliidae. In fact, as pointed out by Ghedotti (2000: 25): "Parenti (1981) and Costa (1998) recognized high pectoral fins as a synapomorphic reversal in poeciliids to the condition in non-cyprinodontiform atherinomorphs".

\section{Pelvic fin and girdle}

Character 33 - Number of pelvic-fin rays in males: (0) six; (1) five; (2) four; (3) three.

Males of most atherinomorph fishes have six pelvic-fin rays (state 0) (Parenti, 1981; Ghedotti, 2000). Ghedotti (2000) reported less than six pelvic-fin rays as synapomorphic for Phallotorynus, Phalloceros, Cnesterodon and Tomeurus. 
Males specimens of Phalloceros and Phallotorynus species as well as Cnesterodon n. sp. A, Cnesterodon n. sp. B, and $C$. hypselurus possess five pelvic-fin rays (state 1). Males of Cnesterodon brevirostratus, C. septentrionalis, $C$. carnegiei, and C. omorgmatos, Phalloptychus januarius and $P$. iheringii exhibit four pelvic-fin rays (state 2). Males of Cnesterodon raddai Meyer \& Etzel and Tomeurus possess three pelvic-fin rays (state 3 ). Cnesterodon decemmaculatus (Jenyns) was coded "-" for it is polymorphic, males having four or five pelvic-fin rays. Phalloptychus eigenmanni Henn was coded "?" for character state could not be checked due to poor condition of the material studied. According to the present phylogenetic hypothesis state 1 is interpreted as synapomorphic for a clade containing Cnesterodon, Phallotorynus, and Phalloceros [Clade 111]. State 2 is hypothesized as independently acquired and synapomorphic for Phalloptychus species and for the clade [Cnesterodon brevirostratus $+C$. septentrionalis $+C$. carnegiei $+C$. omorgmatos]. The presence of state 3 in $C$. raddai and Tomeurus is considered homoplastic.

Character 34 - Pelvic-fin length in adult males: (0) short; second ray not surpassing the end of anal-fin base; (1) long, second ray surpassing the end of anal-fin base.

In most cyprinodontiform fishes the second pelvic-fin ray does not surpass the end of anal-fin base (state 0). In Xenophallus, Xiphophorus, Xenodexia, Poecilia, Limia, Pamphorichthys, Micropoecilia, and "Poecilia" the second pelvic-fin ray surpasses the end of anal-fin base (state 1). Following our phylogenetic study, second pelvic-fin ray surpassing the end of anal-fin base is hypothesized to have been independently acquired by Xenophallus and by the ancestor of a clade comprising Xiphophorus, Xenodexia, Poecilia, Limia, Pamphorichthys, Micropoecilia, and "Poecilia" [Clade 108]. Rodriguez (1997) reported this feature as synapomorphic for Xiphophorus, Poecilia, Limia, and Pamphorichthys.

Character 35 - Position of pelvic girdle of males: (0) very posterior, anterior border of basipterygium posterior to posterior border of cleithrum; (1) posterior; posterior border of cleithrum approximately aligned with center of basipterygium (or more posterior); (2) not very anterior; posterior border of basipterygium aligned with posterior border of cleithrum; (3) very anterior; located below pectoral girdle; posterior border of basipterygium anterior to posterior border of cleithrum; (4) posterior border of cleithrum approximately aligned with anterior border of basipterygium.

Pelvic girdle of males of Aplocheilichthys, Fluviphylax, Jenynsia, Cyprinodon, Fundulus, Brachyrhaphis, Gambusia, Belonesox, Girardinus, Xiphophorus, Xenodexia, Poecilia, Micropoecilia, and "Poecilia" is very posterior, anterior border of basipterygium being posterior to posterior border of cleithrum (state 0 ).

In Alfaro, Priapella, Priapichthys, Heterandria, Pseudopoecilia, Phallichthys, Poeciliopsis, Phalloptychus, Quintana, Carlhubbsia, Pamphorichthys scalpridens,
Phallotorynus, Phalloceros n. sp. B, and Phalloceros n. sp. $D$ pelvic girdle of males is posteriorly located, with posterior border of cleithrum approximately aligned with center of basipterygium (or more posterior) (state1).

In Neoheterandria, Pamphorichthys hollandi, and Phalloceros species excepting Phalloceros n. sp. B, and Phalloceros n. sp. D pelvic girdle is not very anteriorly located, with posterior border of basipterygium aligned with posterior border of cleithrum (state 2). In Tomeurus and Cnesterodon the basipterygium is very anterior, located below pectoral girdle; posterior border of basipterygium anterior to posterior border of cleithrum (state 3). In Procatopus, Scolichthys, Xenophallus, and Limia posterior border of cleithrum is approximately aligned with anterior border of basipterygium (state 4). Although this character contributed to the resolution of the present topology, it presented several independent acquisitions and reversals during the history of the Cyprinodontiformes.

Parenti (1981), Costa (1998), and Ghedotti (2000) recognized an anteriorly positioned pelvic girdle as synapomorphic for poeciliids and also recognized the presence of an anterior pelvic girdle in cyprinodontids, and some individuals of Jenynsia. Ghedotti (2000) also described a pelvic girdle under the pectoral girdle in males as synapomorphic for Tomeurus, Cnesterodon, Phalloceros, and Phallotorynus.

Character 36 - Dorsolateral process of basipterygium in adult males (Fig. 8): (0) absent or small; (1) large; (2) enormous.

In most cyprinodontiform fishes a dorsolateral process of basipterygium in adult males is hardly developed or lacking (state 0, Fig. 8a). In Tomeurus, Heterandria, Neoheterandria, Belonesox, Poeciliopsis, and Phalloceros n. sp. U, Phalloceros n. sp. T, and Phalloceros n. sp. S this process is large (state 1, Fig. 8b). In Phalloptychus this process is enormous; it is as long as the remaining basipterygium (state 2, Fig. 8c; 15). Based on present analysis of relationships, state 1 is interpreted as independently evolved in Tomeurus, Heterandria, Neoheterandria, Belonesox, Poeciliopsis, and in the ancestor of Clade 82, with a reversal in Clade 78. State 2 is hypothesized as synapomorphic for Phalloptychus species.

Character 37 - Shape of the anterior tip of basipterygium in adult males: (0) approximately triangular and rounded; (1) clearly pointed; (2) sinuous; (3) clearly round and keeled.

Among studied taxa, Aplocheilichthys, Fluviphylax, Jenynsia, Fundulus, Alfaro, Brachyrhaphis, Neoheterandria, Scolichthys, Phallichthys, Carlhubbsia, Micropoecilia, "Poecilia", Phallotorynus, and Phalloceros n. sp. B possess the anterior tip of basipterygium approximately triangular and round in adult males (state 0, Fig. 8d). In Cnesterodon species this structure is sinuous (state 2, Fig. 9), this condition being synapomorphic for the genus. In Poeciliopsis and Phalloptychus the anterior tip of basipterygium is clearly round and keeled in adult males (state 3 , Fig. 8c), which is 
interpreted as synapomorphic for this clade. Remaining studied taxa exhibit a clearly pointed anterior tip of basipterygium in adult males (state 1, Fig. 11).

Character 38 - Lateral keel of basipterygium in adult males: (0) absent; (1) present.

Most cyprinodontiforms lack a lateral keel of basipterygium in adult males. This derived feature appeared to have been independently acquired by Scolichthys, Pamphorichthys, and by the ancestor of Poeciliopsis and Phalloptychus.

Character 39 - Narrowing of lateral surface of basipterygium base in adult males (Fig. 9): (0) absent; (1) present.
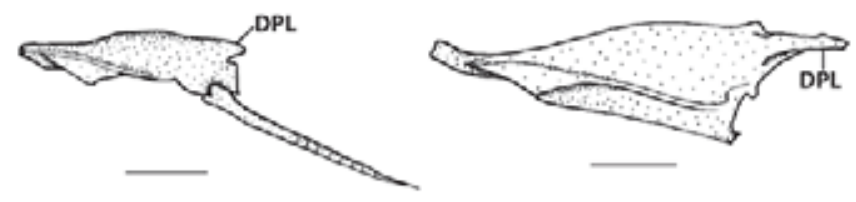

a

b
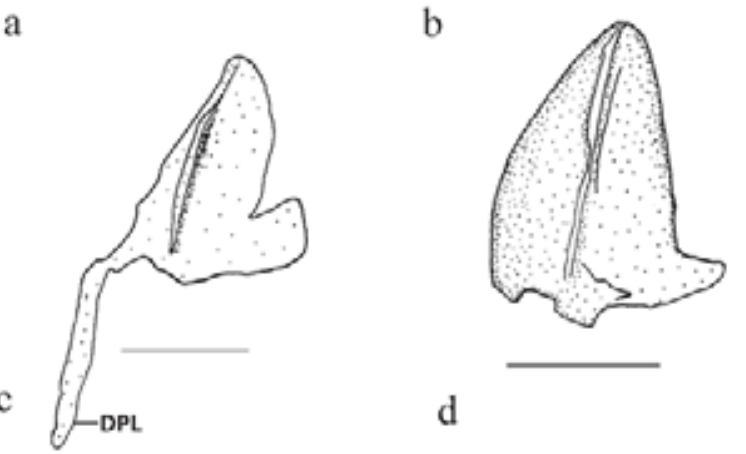

Fig. 8. Left basipterygium. (a) Priapichthys annectens, ANSP 163139; (b) Heterandria jonesii, UMMZ 210999; (c) Phalloptychus iheringii, MCP 11054; (d) Micropoecilia branneri, MCP 22040. DLP = dorsolateral process. Scale bar $1 \mathrm{~mm}$. A and B lateral view. C and D ventral view.

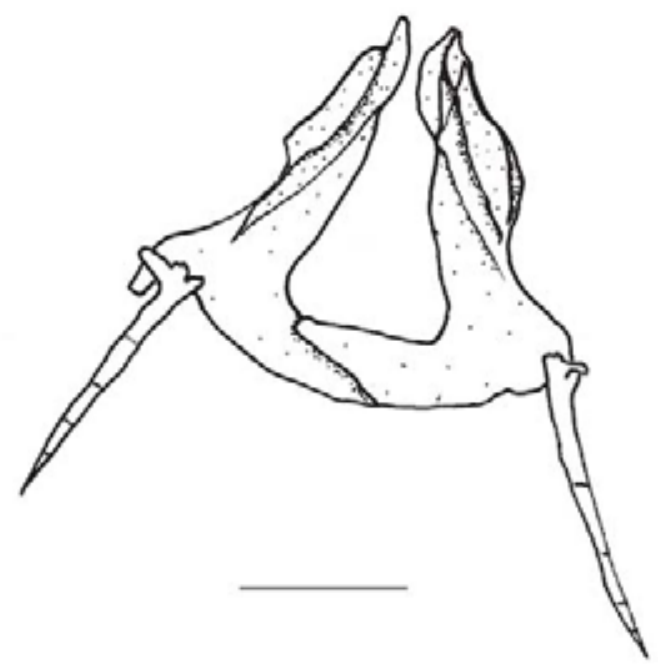

Fig. 9. Basipterygia and first pelvic-fin ray of Cnesterodon brevirostratus, MCP 13950. Scale bar $1 \mathrm{~mm}$.
Cnesterodon is unique among cyprinodontiforms by the narrowing of lateral surface of basipterygium base in adult males (state 1; Fig. 9). This condition is absent in remaining atherinomorphs (state 0) and is interpreted as synapomorphic for Cnesterodon.

Character 40 - First ray of left and right pelvic fins in adult males (Fig. 9, 10): (0) similar to each other; (1) different from each other.

All cyprinodontiform fishes possess first ray of left and right pelvic fins similar to each other in adult males (state 0, Fig. 9), except for Phalloptychus species, in which first ray of left pelvic fin is much wider and more specialized than right one (state 1; Fig. 10). This condition is hypothesized as synapomorphic for Phalloptychus.

Character 41 - Width of first pelvic-fin ray in adult males: (0) approximately constant tapering gradually to tip; (1) decreasing abruptly at distal portion, distal slender portion long; (2) decreasing abruptly at distal portion, distal slender portion short; (3) very wide, mainly right one.

Among studied taxa, members of the outgroup, Alfaro, Brachyrhaphis, Priapella, Priapichthys, Pseudopoecilia, Gambusia, Belonesox, Phallichthys, Quintana, Carlhubbsia, Xenodexia, Xiphophorus, Pamphorichthys, Micropoecilia, "Poecilia”, Phallotorynus, and Phalloceros n. sp. R possess pelvic-fin ray gradually tapering to tip (state 0) in adult males.

In Neoheterandria, Heterandria, Girardinus, Xenophallus, Poeciliopsis, Poecilia, Limia, Phalloceros, (except Phalloceros n. sp. R) width of first pelvic-fin ray in adult males decreases abruptly at distal portion, and distal slender portion is long (state 1, Fig. 11). In adult males of Tomeurus and Cnesterodon, the first pelvic-fin ray decreases abruptly at distal portion, and distal slender portion is short (state 2, Fig. 9), which is synapomorphic for the genus and independently acquired in Tomeurus. In Phalloptychus the first pelvic-fin ray in adult males is very wide, especially the right (state 3, Fig. 10). This condition is interpreted as synapomorphic for Phalloptychus.

Character 42 - Second pelvic-fin ray in adult males: (0) branched; (1) unbranched.

Second pelvic-fin ray is branched (state 0 ) in adult males of cyprinodontiforms, with the exception of Tomeurus and Cnesterodon species, which possess unbranched second pelvic-fin ray (state 1). Following the present hypothesis, Tomeurus and Cnesterodon independently acquired an unbranched second pelvic-fin ray in adult males. A reversal occurs in C. septentrionalis.

Character 43 - Lateral projection near the bifurcation of second right pelvic-fin ray in adult males (Fig. 10a): (0) absent; (1) present.

Phalloptychus is unique among cyprinodontiform fishes by the possession of a lateral projection near the bifurcation of second right pelvic-fin ray in adult males (Fig. 10a). This condition is interpreted as synapomorphic for Phalloptychus. 


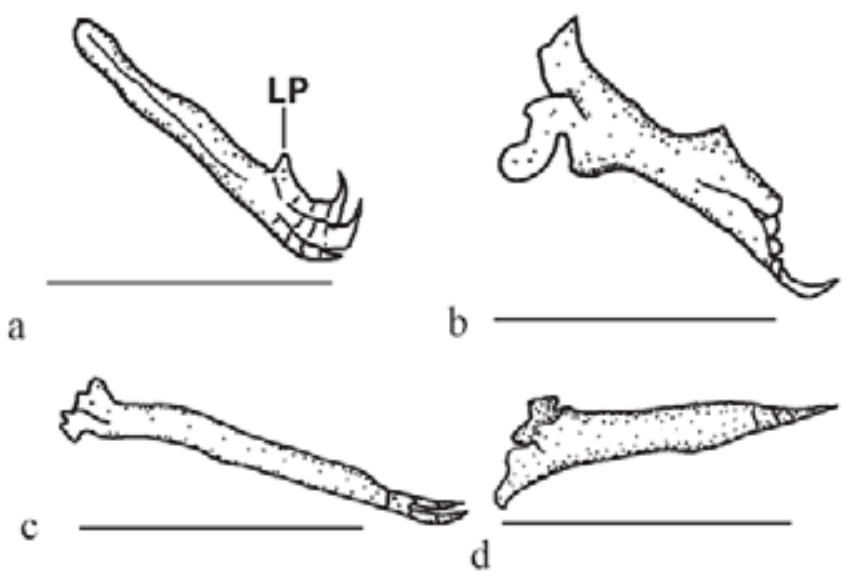

Fig. 10. First and second pelvic-fin rays in adult male of Phalloptychus iheringii, MCP 11054. (a) Second right pelvic-fin ray; (b) first right pelvic-fin ray; (c) second left pelvic-fin ray; (d) first left pelvic-fin ray. $\mathrm{LP}=$ lateral projection. Scale bar $1 \mathrm{~mm}$.

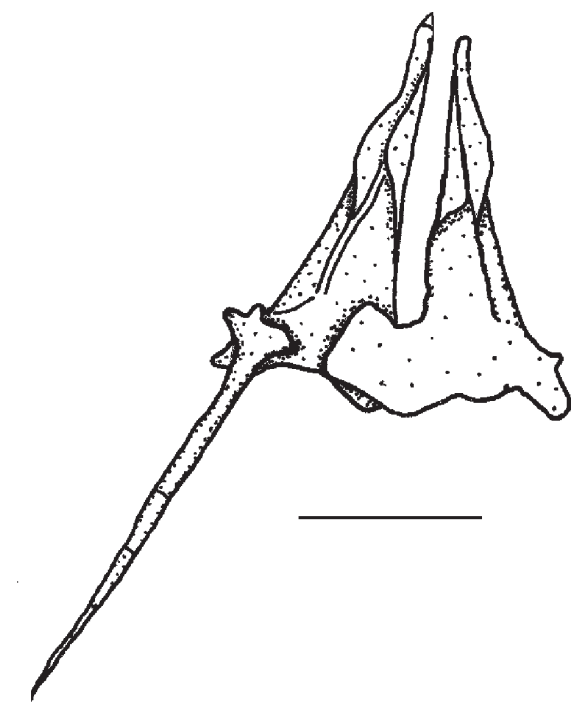

Fig. 11. Basipterygia and first pelvic-fin ray of Phalloceros n. sp. G, MCP 30509. Scale bar $1 \mathrm{~mm}$.

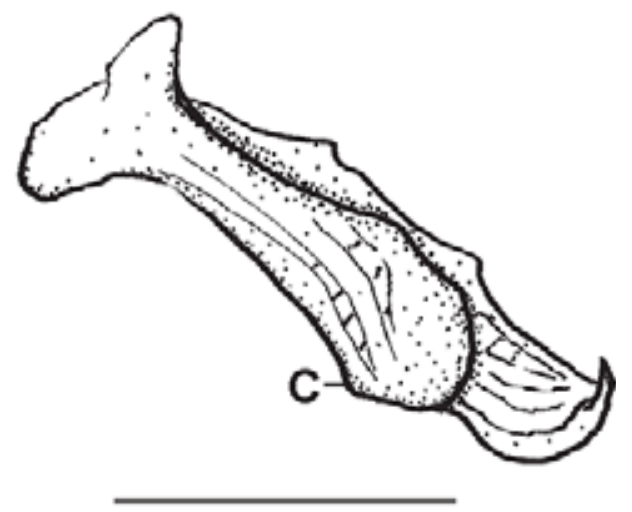

Fig. 12. First right pelvic-fin ray in adult male of Phalloptychus iheringii, MCP 11054. C = callosity. Scale bar $1 \mathrm{~mm}$.
Character 44 - Number of pelvic-fin rays in females: (0) six or seven; (1) five; (2) three.

Females of most cyprinodontiforms possess six or seven pelvic-fin rays (state 0 ). Ghedotti (2000) reported less than six pelvic-fin rays as synapomorphic for Phallotorynus, Phalloceros, Cnesterodon and Tomeurus.

Females of Phalloptychus, Cnesterodon, Phallotorynus, and Phalloceros possess five anal-fin rays (state 1). Females of Tomeurus exhibit three pelvic-fin rays (state 2). Tracking the present historical hypothesis for poeciliines, state 1 is proposed as synapomorphic for Phalloptychus januarius and $P$. iheringii. This derived feature is independently acquired by and also synapomorphic for a clade embracing Cnesterodon, Phallotorynus, and Phalloceros [Clade 111].

Character 45 - Callosity at the distal portion of first right pelvic fin in adult males (Fig. 12): (0) absent; (1) present.

Phalloptychus is unique among cyprinodontiform fishes by the possession of a callosity at the distal portion of right pelvic fin in adult males. This condition is interpreted as synapomorphic for Phalloptychus (state 1; Fig. 12).

\section{Axial skeleton}

Character 46 - Ligastyle (Fig. 13): (0) absent; (1) with one axis; (2) triangular; (3) tripartite (three axis).

Ghedotti (2000) reported the presence of an ossified ligastyle in Alfaro, Priapella, Gambusia, Heterandria, Poeciliopsis, Girardinus, Phallichthys, Phallotorynus, Phalloceros, and Cnesterodon.

A ligastyle is absent in Aplocheilichthys, Fluviphylax, Procatopus, Jenynsia, Fundulus, Tomeurus, Pseudopoecilia, Scolichthys, Poecilia, Limia, Pamphorichthys, Micropoecilia, "Poecilia", and Cnesterodon (state 0). Cyprinodon, Alfaro, Brachyrhaphis, Gambusia, Priapichthys, Poeciliopsis, Xenophallus, Xiphophorus, Xenodexia, Carlhubbsia, Phallotorynus, and Phalloceros possess a rod-like monoaxial ligastyle (state 1, Fig. 13a). The ligastyle is triangular (state 2, Fig. 13b) in Priapella, Heterandria, Belonesox, Girardinus, Phallichthys, and Quintana; whereas Phalloptychus and Neoheterandria possess a tripartite ligastyle (state 3, Fig. 13c). Although this character contributed to the resolution of the present topology, it presented several independent acquisitions and reversals during the history of the Cyprinodontiformes.

Character 47 - Haemal arch and spine of vertebrae 13-17 in adult males: (0) typical and similar to the remaining; (1) absent; (2) modified in gonapophyses; (3) modified in rudimentary gonapophyses.

Haemal arch and spine of vertebrae 13-17 in adult males are typical and similar to the remaining vertebrae in the outgroup and Alfaro (state 0). These are absent (state 1) in Tomeurus and are modified in gonapophyses (state 2) in all remaining poeciliines. In Cnesterodon, gonapophyses are rudimentary (state 3 ). Tracking the evolutive history of this character reveals that: (1) plesiomorphic condition is only kept by Alfaro; (2) Tomeurus lacked the haemal arch and spine 
of vertebrae 13-17 in adult males; (3) haemal arch and spine of vertebrae 13-17 in adult males were modified in gonapophyses in the ancestor of all remaining poeciliines; (4) Cnesterodon shows a hypotrophy of gonapophyses to a vestigial stage.

Rosen \& Bailey (1963) described the structure and distribution of gonapophyses in many poeciliines. Ghedotti (2000) reported the presence of gonapophyses in poeciliines, except in Tomeurus and Cnesterodon.

Character 48 - Number of well-developed gonapophyses: (0) zero (absent); (1) three; (2) two, rarely one; (3) four.

Among studied taxa, members of the outgroup, Tomeurus, Alfaro, and Cnesterodon species lack well-developed gonapophyses (state 0). Poecilia, Limia, Pamphorichthys, Micropoecilia, and "Poecilia" possess two (rarely one) welldeveloped gonapophyses (state 2). Xenodexia exhibit four well-developed gonapophyses (state 3 ). The remaining studied taxa present three well-developed gonapophyses (state 1). Results of the present phylogenetic analysis support the following interpretation of character evolution: (1) state 1 appeared once in the history of poeciliines in the ancestor of members of Clade 125 ; (2) this state is posteriorly modified to state 2 in the ancestor of members of Clade 99; (3) state 3 is interpreted as autapomorphic for Xenodexia; and (4) a reversal to state 0 occurred in Cnesterodon.

Character 49 - Position of functional gonapophyses: (0) absent; (1) on vertebrae 14, 15, 16; (2) located between vertebrae 13 to 15 , but never on vertebra 16 (13-14-15; 14-15; 13 $14 ; 13) ;(3)$ on vertebrae 15,16 , and 17 ; (4) on vertebrae 13-16 or 14-17.

Functional gonapophyses are absent in members of the outgroup and in Tomeurus, Alfaro, and Cnesterodon (state $0)$. Functional gonapophyses are located on vertebrae 14, 15, 16 (state 1). Functional gonapophyses are located on vertebrae13 to 15 , but never on vertebra 16 (13-14-15; 14-15; 13-14; 13) (state 2). Functional gonapophyses are located on vertebrae 15, 16, and 17 (state 3). Functional gonapophyses are located on vertebrae 13-16 or 14-17 (state 4). Our results support the assumption that state 1 is synapomorphic for a clade comprising all poeciliines but Tomeurus and Alfaro [Clade 125], with a reversal to state 0 in Cnesterodon [Clade 0107]. State 2 is interpreted as a synapomorphy for the clade $[$ Poecilia + Limia + Pamphorichthys + Micropoecilia + "Poecilia"] [Clade 99]. State 3 and 4 are considered as autapomorphic for Phalloceros n. sp. R and for Xenodexia, respectively.

Character 50 - First gonapophysis reduced to a support for the adjacent gonapophysis located in vertebra 12 or 13 (Rodriguez, 1997: fig. 4B): (0) absent; (1) present.

Rodriguez (1997) proposed that Pamphorichthys is unique among cyprinodontiform fishes by the possession of a reduced gonapophysis to a support for the adjacent gonapophysis located in vertebra 12 or 13 . This condition is interpreted as synapomorphic for Pamphorichthys.

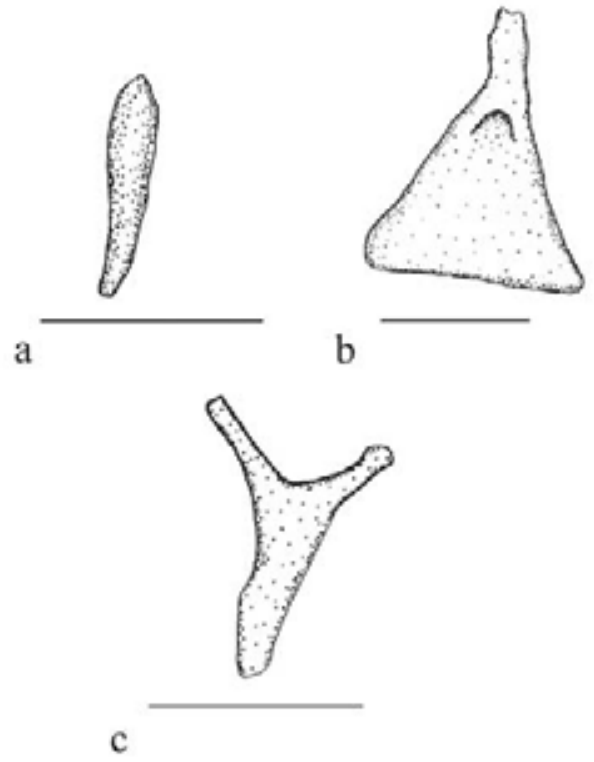

Fig. 13. Ligastyle of (a) Carlhubbsia kidderi, UMMZ 184619; (b) Heterandria jonesii, UMMZ 210999; (c) Phalloptychus iheringii, MCP 11054. Scale bar $1 \mathrm{~mm}$.

Character 51 - Hollister's foramen on first or second gonapophysis (Rodriguez, 1997: fig. 4B): (0) absent; (1) present.

Rodriguez (1997) reported the presence of Hollister's foramen on first or second gonapophysis as synapomorphic for Pamphorichthys, Poecilia, and Limia. However, we did not observe this feature in Limia. We have observed this feature in Poecilia, Pamphorichthys, Micropoecilia, and "Poecilia". Hollister's foramen on first or second gonapophysis is herein interpreted as synapomorphic for a clade containing Poecilia, Pamphorichthys, Limia, Micropoecilia, and "Poecilia", with a reversal in Limia.

Character 52 - Gonapophysis of vertebra 14: (0) slightly curved; (1) very curved; (2) straight; (3) rudimentary; (4) bearing an abrupt break forming an acute angle at subdistal portion.

Gonapophysis of vertebra 14 is slightly curved (state 0 , Rosen \& Bailey, 1963: fig. 46) in Brachyrhaphis, Priapichthys, Priapella, Heterandria, Gambusia, Belonesox, Pseudopoecilia, Neoheterandria, Scolichthys, Girardinus, Phallichthys, Xenophallus, Quintana, Carlhubbsia, Xenodexia, Poecilia, Limia, Pamphorichthys, Micropoecilia, and "Poecilia". In Poeciliopsis and Phalloptychus gonapophysis of vertebra 14 is strongly curved (state 1, Rosen \& Bailey, 1963: fig. 26C; 56A-D). Gonapophysis of vertebra 14 is straight (state 2, Rosen \& Bailey, 1963: fig. 24A) in Xiphophorus and Phalloceros n. sp. $\mathrm{J}$. Gonapophysis of vertebra 14 is rudimentary (state 3, Rosen \& Bailey, 1963: fig. 26D) in Cnesterodon. Phalloceros species except Phalloceros n. sp. J. possess gonapophysis of vertebra 14 bearing an abrupt break forming an acute angle at 
subdistal portion (state 4, Rosen \& Bailey, 1963: fig. 29B). The present phylogenetic analysis indicate: (1) state 1 as synapomorphic for Poeciliopsis + Phalloptychus [Clade 105]; (2) state 2 independently acquired in Xiphophorus and Phalloceros n. sp. J; (3) state 3 synapomorphic for Cnesterodon; and (4) state 4 as synapomorphic for Phalloceros species, with subsequent change to state 2 in Phalloceros n. sp. J.

Character 53 - Curvature of first gonapophysis relative to vertebral column: (0) 46-75 degrees; (1) 16-45 degrees; (2) 515 degrees; (3) zero degree (approximately parallel); (4) approximately 90 degrees (approximately perpendicular).

In Brachyrhaphis, Priapichthys, Phallichthys, Quintana, and Xenodexia first gonapophysis is angled 46-75 degrees relative to vertebral column (state 0). In Priapella, Heterandria, Belonesox, Neoheterandria, Scolichthys, Girardinus, Xenophallus, Carlhubbsia, Poecilia, Limia, Phallotorynus, Phalloceros (except Phalloceros n. sp. C), the first gonapophysis is angled 16-45 degrees relatively to vertebral column (state 1). A curvature of 5-15 degrees (state 2) is present in Gambusia, Pseudopoecilia, Poeciliopsis, Micropoecilia sp., "Poecilia", and Phalloceros n. sp. C. In Phalloptychus, Pamphorichthys, Micropoecilia branneri (Eigenmann), first gonapophysis is parallel to vertebral column (state 3). In Xiphophorus, first gonapophysis is approximately perpendicular to vertebral column (state 4). Outgroup taxa, Tomeurus, Alfaro, and Cnesterodon were coded "-." for they lack gonapophysis 1 . Although this character contributed to the resolution of the present topology, it presented several independent acquisitions and reversals during the history of the Cyprinodontiformes.

The curvature of gonapophyses (in general) was employed by Rodriguez (1997), however, this author codified only two character states: gonapophyses forming an acute angle relative to vertebral column and perpendicular to vertebral column.

Character 54 - Curvature of second gonapophysis relative to vertebral column: (0) 15-45 degrees; (1) 45-70 degrees; (2) zero degrees (approximately parallel); (3) zero-15 degrees; (4) approximately 90 degrees (approximately perpendicular).

In Priapella, Heterandria, Belonesox, Pseudopoecilia, Neoheterandria, Scolichthys, Girardinus, Phallichthys, Xenophallus, Poeciliopsis, Poecilia, Phallotorynus, and Phalloceros (except Phalloceros n. sp. B) second gonapophysis is angled 15-45 degrees relative to vertebral column (state 0). In Priapichthys, Quintana, Carlhubbsia, and Xenodexia the second gonapophysis is angled 45-70 degrees relatively to vertebral column (state 1). In Phalloptychus, Pamphorichthys, Micropoecilia branneri, second gonapophysis is approximately parallel to vertebral column (state 2). A curvature of zero-15 degrees (state 3 ) is present in Gambusia, Micropoecilia branneri, and "Poecilia". In Brachyrhaphis and Xiphophorus second gonapophysis is approximately perpendicular to vertebral column (state 4). Outgroup taxa, Tomeurus, Alfaro, and Cnesterodon were coded "-" for they lack gonapophysis 2.
Although this character contributed to the resolution of the present topology, it presented several independent acquisitions and reversals during the history of the Cyprinodontiformes.

Character 55 - Curvature of third gonapophysis relative to vertebral column: (0) 90 degrees (approximately perpendicular); (1) 35-70 degrees; (2) 10-32 degrees; (3) zero-10 degrees; (4) zero (parallel).

In Brachyrhaphis and Xiphophorus, third gonapophysis is approximately perpendicular to vertebral column (state 0 ). In Belonesox, Priapella, Priapichthys, Quintana, Carlhubbsia, and Xenodexia third gonapophysis is angled 35-70 degrees relatively to vertebral column (state 1). A curvature of 10-32 degrees (state 2) is present in Heterandria, Pseudopoecilia, Scolichthys, Girardinus, Xenophallus, Poeciliopsis, Phallotorynus, and Phalloceros. In Phalloptychus third gonapophysis is angled zero-10 degrees relatively to vertebral column (state 3). In Gambusia third gonapophysis is approximately parallel to vertebral column (state 4). Outgroup taxa, Tomeurus, Alfaro, Poecilia, Limia, Pamphorichthys, Micropoecilia, "Poecilia", and Cnesterodon were coded "-" for they lack third gonapophysis.

The present phylogenetic analysis indicates that state 1 appeared at the ancestor of Clade 124. State 2 is supposed to have been acquired by the ancestor of members of Clade 122, with reversals to state 1 in Belonesox, Phallichthys, and in Clade 112. A reversal to state 0 occurs in Xiphophorus. State 3 is interpreted as synapomorphic for Phalloptychus.

Character 56 - Distal portion of ribs $(6,7$, and 8$)$ in adult males (Fig. 14): (0) not expanded; (1) expanded.

Adult males of cyprinodontiform fishes (with the exception of Cnesterodon species) exhibit the distal portions of pleural ribs 6, 7, and 8 not expanded (state 0). Rosa \& Costa (1993) recognized the presence of winglike expansions on distal portions of male pleural ribs, as synapomorphic for Cnesterodon species. Cnesterodon is unique among cyprinodontiforms by the expansion of distal portion of pleural ribs 6, 7, and 8 in adult males (state 1). This condition is herein also interpreted as synapomorphic for Cnesterodon species.

Character 57 - Length of pleural rib 7 in adult males (Fig. 14): (0) shorter than pleural rib 8; (1) longer than pleural rib 8.

In most cyprinodontiforms the distal tip of pleural rib 7 in adult males does not surpass that of pleural rib 8 (state 0 ). Cnesterodon is unique among cyprinodontiforms by the length of pleural rib 7 in adult males, which surpasses that of pleural rib 8. This condition is interpreted as synapomorphic for Cnesterodon (state 1). The possession of this state by Phalloceros n. sp. I is assumed as homoplastic.

Character 58 - Pleural rib 9 in adult males (Fig. 15): (0) normally developed; (1) well-developed.

Most cyprinodontiform fishes possess the pleural rib normally developed, i.e. similar to the remaining 
atherinomorphs (state 0). Phalloptychus is unique among cyprinodontiform fishes by having pleural rib 9 well-developed in adult males, i.e. longer than remaining pleural ribs, curved forward and expanded at distal tip (state 1). This condition is interpreted as synapomorphic for Phalloptychus.

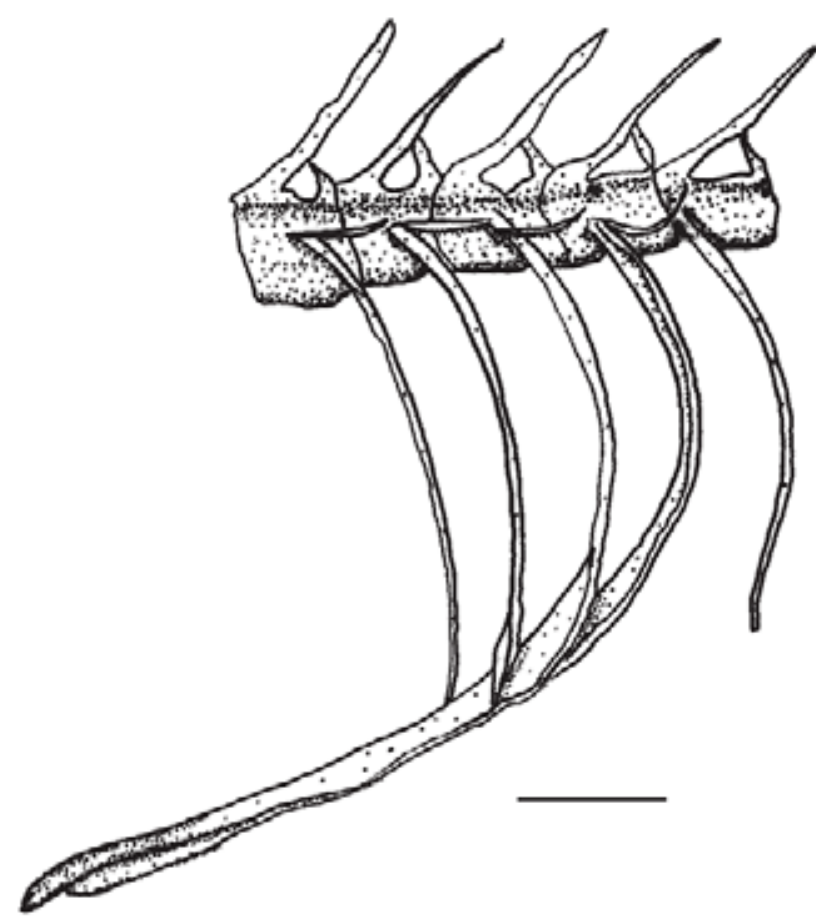

Fig. 14. Pleural ribs 5-9 in adult male of Cnesterodon brevirostratus, MCP 13950. Scale bar $1 \mathrm{~mm}$.

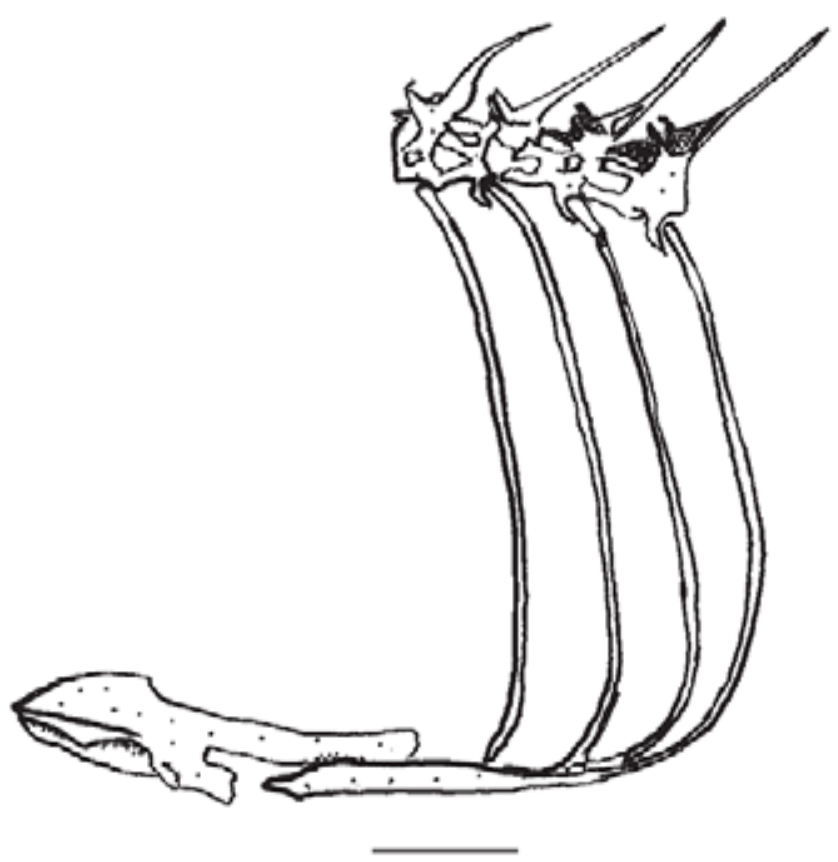

Fig. 15. Basipterygium and pleural ribs 6-9 in adult male of Phalloptychus iheringii, MCP 11054. Scale bar $1 \mathrm{~mm}$.
Character 59 - Curvature of pleural ribs in adult males: (0) approximately parallel and slightly arched forward, their distal tip not converging to the same point; (1) pleural ribs 7,8 , and 9 are curved forward not converging to the same point towards pelvic girdle; (2) pleural ribs 6,7 , and 8 are curved forward converging to the same point towards pelvic girdle.

Pleural ribs 6-9 of males of most cyprinodontiform fishes are approximately parallel and slightly arched forward, their distal tip not converging to the same point (state 0). In Priapella, Heterandria, Pseudopoecilia, Neoheterandria, Scolichthys, Girardinus, Phallichthys, Xenophallus, Poeciliopsis, Phalloptychus, Quintana, and Carlhubbsia pleural ribs 7, 8, and 9 are curved forward not converging to the same point towards pelvic girdle (state 1). In Cnesterodon species, excepting C. raddai, Phallotorynus and Phalloceros pleural ribs 6,7 , and 8 are curved forward converging to the same point towards pelvic girdle (state 2 ).

The curvature of pleural ribs in adult males was described and discussed by Rosen \& Bailey (1963) and Rosa \& Costa (1993). Ghedotti (2000: 24) discussed the rib condition in adult male. However, the rib condition of Tomeurus as described by Ghedotti (2000) himself is far autapomorphically peculiar and different from states 1 and 2 of the present character, therefore Tomeurus was coded 0 for this character.

Results of the present phylogenetic analysis support the following interpretation of character evolution: (1) state 1 appeared once in the history of poeciliines in the ancestor of members of Clade 123, with reversals in the Gambusia + Belonesox clade [Clade 118] and in the clade composed of Xiphophorus, Xenodexia, Poecilia, Limia, Pamphorichthys, Micropoecilia, and "Poecilia" [Clade 108]; (2) state 2 is synapomorphic for a clade comprising Cnesterodon, Phallotorynus, and Phalloceros [Clade 111], with a reversal to state 0 in Cnesterodon raddai.

Character 60 - Pleural ribs association with haemal arches in males: (0) absent; (1) present.

There is no consensus among authors concerning this character. Basal atherinomorph fishes do not exhibit pleural ribs associated with haemal arches (state 0). Parenti (1981) recognized pleural ribs on haemal arches as synapomorphic for Poeciliidae. However, Costa (1998) did not notice the derived feature in the poeciliids examined by him: Alfaro, Aplocheilichthys Brachyrhaphis, Cnesterodon, Fluviphylax, Hylopanchax, Limia, Pamphorichthys, Phalloceros, Phalloptychus, Poecilia, Procatopus, Tomeurus, and Xiphophorus.

On the other hand, Ghedotti (2000) reported pleural ribs on haemal arches in Aplocheilichthys, Micropanchax Myers, Procatopus, Fluviphylax, Cubanichthys, Cyprinodon, and all poeciliines examined (except Tomeurus and Poeciliopsis): Alfaro, Priapella, Gambusia, Heterandria, Girardinus, Poecilia, Phallichthys, Phallotorynus, Phalloceros, and Cnesterodon.

We opted to examine this character in males and females separately, i.e. we split this character in two, because the 
presence of haemal arches associated with pleural ribs may vary between sexes. Pleural ribs associated with haemal arches were found in males of Alfaro, Gambusia, Belonesox, Priapella, Phalloptychus, Scolichthys, Poecilia, "Poecilia", Xiphophorus, Limia, Pamphorichthys, Micropoecilia, Carlhubbsia, Xenodexia, Cnesterodon (except $C$. septentrionalis), Phalloceros, and Phallotorynus. We interpreted this character as independently acquired in Alfaro, Priapella, in Gambusia + Belonesox clade, Scolichthys, Phalloptychus, in the ancestor of members of Clade 115, with reversals in C. septentrionalis and Quintana.

Character 61 - Pleural ribs association with haemal arches in females: (0) absent; (1) present.

Pleural ribs associated with haemal arches were found in females of Alfaro, Priapella, Gambusia, Phalloptychus, Quintana, Poecilia, "Poecilia", Xiphophorus, Limia, Pamphorichthys, Micropoecilia, Carlhubbsia, and Xenodexia, Cnesterodon decemmaculatus, C. hypselurus, Cnesterodon n. sp. A, C. omorgmatos, C. brevirostratus, Phallotorynus (except Phallotorynus n. sp. A), and Phalloceros.

Although this character contributed to the resolution of the present topology, it presented several independent acquisitions and reversals during the history of the Cyprinodontiformes.

\section{Dorsal Fin}

Character 62 - Position of the first proximal radial of dorsal fin in adult males: Located between neural arches of vertebrae: (0) 12 and 13; (1) 13 and 14; (2) 8 and 9; (3) 23 and 24 or 24 and 25 ; (4) 10 and 11 ; (5) 15 and 16 or 16 and 17; (6) 11 and 12; (7) 14 and $15 ;(8) 7$ and 8.

Ghedotti (2000) studied the position of dorsal-fin origin relative to the origin of anal fin. We opted to examine this character by means of the position of the first proximal radial of dorsal fin in adult males relative to neural arches of vertebrae. We also examined males and females separately, i.e. we split this character in two, because the position of dorsaland anal-fin origins may vary between sexes.

First proximal radial of dorsal fin in adult males is located between neural spines of vertebrae 12 and 13 (state 0) in Fundulus, Priapichthys, Priapella, Poeciliopsis, Phalloptychus, "Poecilia", Cnesterodon decemmaculatus, and Cnesterodon n. sp. B.

In Gambusia, Pseudopoecilia, Scolichthys, Girardinus, Micropoecilia, Cnesterodon n. sp. A, C. brevirostratus, C. carnegiei, C. omorgmatos, Phallotorynus, and most Phalloceros species (except Phalloceros n. sp. U, Phalloceros n. sp. R, Phalloceros n. sp. N, Phalloceros n. sp. O, Phalloceros n. sp. M, Phalloceros n. sp. H, and Phalloceros n. sp. J) the first proximal radial of dorsal fin in adult males is located between neural spines of vertebrae 13 and 14 (state 1).

Neoheterandria, Carlhubbsia, and Xiphophorus exhibit this structure located between neural spines of vertebrae 8 and 9 (state 2). In Tomeurus the first proximal radial of dorsal fin in adult males is located between neural spines of vertebrae 23 and 24 or 24 and 25 (state 3). Jenynsia, Phallichthys,
Xenophallus, Limia, and Pamphorichthys present this element located between neural spines of vertebrae 10 and 11 (state 4)

In Fluviphylax, this radial is located between neural spines of vertebrae 15 and 16 or 16 and 17 (state 5). Brachyrhaphis, Heterandria, Quintana, Xenodexia, Poecilia, and Cnesterodon septentrionalis possess the first proximal radial of dorsal fin in adult males located between neural spines of vertebrae 11 and 12 (state 6). In Phalloceros n. sp. U, Phalloceros n. sp. R, and Phalloceros n. sp. O, this structure is located between neural spines of vertebrae 14 and 15 (state 7) and in Cyprinodon it is located between neural spines of vertebrae 7 and 8 (state 8 ).

Although this character contributed to the resolution of the present topology, it presented several independent acquisitions and reversals (24 steps) during the history of the Cyprinodontiformes.

Character 63 - Position of the first proximal radial of dorsal fin in adult females: Located between neural arches of vertebrae: (0) 12 and 13; (1) 13 and 14; (2) 10 and 11; (3) 11 and 12; (4) 14 and 15; (5) 15 and 16; (6) 23 and 24 or 24 and 25; (7) 8 and 9.

First proximal radial of dorsal fin in adult females located between neural spines of vertebrae 12 and 13 (state 0 ) in Aplocheilichthys, Fundulus, Phalloptychus, Poeciliopsis, $C$. brevirostratus, C. carnegiei, and C. omorgmatos. In Belonesox, Pseudopoecilia, Scolichthys, Girardinus, Micropoecilia, Cnesterodon n. sp. A, Cnesterodon n. sp. B., Phallotorynus jucundus, $P$. victoriae, Phallotorynus $\mathrm{n}$. sp. B, and Phalloceros species (except Phalloceros n. sp. P, Phalloceros n. sp. M, Phalloceros n. sp. J) the first proximal radial of dorsal fin in adult females located between neural spines of vertebrae 13 and 14 (state 1).

Cyprinodon, Phallichthys, Xenophallus, Xenodexia, Limia, and Pamphorichthys exhibit this structure located between neural spines of vertebrae 10 and 11 (state 2). In Brachyrhaphis, Quintana, "Poecilia", and C. septentrionalis the first proximal radial of dorsal fin in adult females is located between neural spines of vertebrae 11 and 12 (state 3). Alfaro, Gambusia, Neoheterandria, Phallotorynus n. sp. A, Phalloceros n. sp. P, Phalloceros n. sp. M, and Phalloceros n. sp. J present this element located between neural spines of vertebrae 14 and 15 (state 4). In Fluviphylax and Phallotorynus fasciolatus this radial is located between neural spines of vertebrae 15 and 16 (state 5). Tomeurus possess the first proximal radial of dorsal fin in adult females located between neural spines of vertebrae 23 and 24 or 24 and 25 (state 6). In Carlhubbsia and Xiphophorus this structure is located between neural spines of vertebrae 8 and 9 (state 7). Although this character contributed to the resolution of the present topology, it presented several independent acquisitions and reversals during the history of the Cyprinodontiformes.

Character 64 - Number of dorsal-fin rays (males and females): (0) ten or more; (1) nine; (2) eight; (3) seven; (4) six. 
Among the studied taxa, Procatopus, Fundulus, Cyprinodon, Alfaro, Priapella, Priapichthys, Heterandria, Pseudopoecilia, Phallichthys, Carlhubbsia, Xiphophorus, Xenodexia, and Phallotorynus jucundus possess 10 or more dorsal-fin rays (state 0). Jenynsia, Brachyrhaphis, Scolichthys, Girardinus, Xenophallus, Phalloptychus, Quintana, and Phalloceros n. sp. S have nine dorsal-fin rays (state 1). Eight dorsal-fin rays (state 2) are present in Aplocheilichthys, Gambusia, Poeciliopsis, Poecilia, Micropoecilia branneri, Cnesterodon, Phallotorynus (except jucundus), and Phalloceros (except Phalloceros n. sp. S). Finally, Pamphorichthys possess seven dorsal-fin rays (state 3), and Tomeurus has six (state 4). Although this character contributed to the resolution of the present topology, it presented several independent acquisitions and reversals during the history of the Cyprinodontiformes. This character was discussed at some length by Ghedotti (2000).

\section{Anal Fin}

Character 65 - Number of anal-fin rays in females: (0) twelve or more; (1) ten; (2) eleven; (3) nine; (4) eight.

Among the studied taxa Aplocheilichthys, Procatopus, Cyprinodon, and Alfaro possess 12 or more anal-fin rays (state 0). Fundulus, Jenynsia, Priapichthys, Brachyrhaphis, Scolichthys, Belonesox, Neoheterandria, Xenophallus, Poeciliopsis, Phalloptychus, Xiphophorus, Limia, "Poecilia", Cnesterodon, Phallotorynus (except $P$. fasciolatus and P. victoriae), Phalloceros n. sp. D, Phalloceros n. sp. P, Phalloceros n. sp. M, and Phalloceros n. sp. Q have 10 anal-fin rays (state 1). Eleven anal-fin rays (state 2), is found in Tomeurus, Priapella, Heterandria, Girardinus, Gambusia, Phallichthys, Pseudopoecilia, Quintana, Carlhubbsia, Xenodexia, Phallotorynus fasciolatus, P. victoriae, and most Phalloceros species. Poecilia, Micropoecilia, and Pamphorichthys have nine anal-fin rays (state 3), and finally Fluviphylax possess eight anal-fin rays (state 4). Although this character contributed to the resolution of the present topology, it presented several independent acquisitions and reversals during the history of the Cyprinodontiformes. This character was discussed at some length by Ghedotti (2000).

Character 66 - Disposition of anal-fin proximal radials of females: (0) parallel; (1) divergent, i.e., first radial slightly inclined forwards; (2) convergent.

Most cyprinodontiform fishes possess anal-fin proximal radials of females in parallel disposition (state 0). Quintana, Carlhubbsia, Phallotorynus victoriae, Phallotorynus jucundus, and Phallotorynus n. sp. A exhibit a divergent disposition of anal-fin proximal radials of females (state 1). Analfin proximal radials of females converge to the same point, i.e., present a convergent disposition in Xenophallus, Poeciliopsis, and Phalloptychus (state 2). The results of the present phylogenetic hypothesis indicate that state 1 was independently acquired by (1) the ancestor of Quintana and Carlhubbsia; and (2) by the ancestor of Phallotorynus victoriae, Phallotorynus jucundus, Phallotorynus n. sp. A, and Phallotorynus n. sp. B, with a reversal in Phallotorynus n. sp. A. State 2 is interpreted as uniquely derived and unreversed synapomorphy for a clade comprising Xenophallus + Poeciliopsis + Phalloptychus [Clade 110].

Character 67 - Second, third, and fourth gonactinosts fused into a complex gonactinost: (0) absent; (1) present.

Second, third, and fourth gonactinosts are fused into a gonactinost complex in all poeciliines except Xenodexia. This feature is therefore hypothesized as a synapomorphy for Poeciliinae with a reversal in Xenodexia.

This character has long been used as diagnostic for poeciliines (e.g. Rosen \& Gordon, 1953; Rosen \& Bailey, 1963).

Character 68 - Inclination of gonactinost complex relative to body longitudinal axis: (0) very inclined backwards, forming a less than 45 degrees angle with body longitudinal axis; (1) gonactinost complex approximately perpendicular to body longitudinal axis; (2) inclined forward, forming a more than 90 degrees angle with body longitudinal axis; (3) little inclined backwards, forming a angle between 45 and 90 degrees with body longitudinal axis.

Ghedotti (2000) employed this character, however, recognizing two states " $(0)$ anteriorly inclined or vertical and (1) posteriorly inclined“. This author reported a posteriorly inclined gonactinost complex as synapomorphic for Cnesterodon and Tomeurus and independently acquired in Alfaro.

In Tomeurus and Cnesterodon the gonactinost complex is very inclined backwards to an angle smaller than $45^{\circ}$ relative to the body longitudinal axis (state 0 ). On the basis of the present hypothesis of relationships, the condition in Cnesterodon is interpreted as a synapomorphic reversal and as plesiomorphic in Tomeurus.

Gonactinost complex is approximately perpendicular to body longitudinal axis (state 1) in Alfaro, Scolichthys, Poecilia, Pamphorichthys, Micropoecilia, "Poecilia", Phalloceros, and Phallotorynus. This condition is herein hypothesized as independent acquisitions in Alfaro, Scolichthys, Poecilia, in Pamphorichthys + Micropoecilia + "Poecilia" Clade [92], and in Phallotorynus + Phalloceros Clade [106].

In Brachyrhaphis, Priapella, Priapichthys, Heterandria, Gambusia, Belonesox, Neoheterandria, Pseudopoecilia, Girardinus, Phallichthys, Xenophallus, Poeciliopsis, Quintana, Carlhubbsia, Xiphophorus, Xenodexia, and Limia the gonactinost complex is inclined forward, forming an angle wider than $90^{\circ}$ relative to the body longitudinal axis (state 2 ). Our results support the supposition that this state is a uniquely derived synapomorphy (with subsequent reversals) acquired by the ancestor of members of Clade 125 .

In Phalloptychus the gonactinost complex is a little inclined backwards, forming an angle of $45^{\circ}$ and $90^{\circ}$ with body longitudinal axis (state 3); this is hypothesized as a uniquely derived and unreversed feature of Phalloptychus species. 
Character 69 - Basal process on first gonactinost: (0) absent; (1) small; (2) large.

Brachyrhaphis, Priapella, Belonesox, Pseudopoecilia, Scolichthys, Girardinus, Carlhubbsia, Xiphophorus, Phallotorynus, and Phalloceros species (except Phalloceros n. sp. A) possess a small basal process on first gonactinost (state 1, Rosen \& Bailey, 1963: fig. 29A). This derived feature presented several independent acquisitions and reversals during the history of the Cyprinodontiformes. In Cnesterodon species this process is enlarged (state 2, Rosen \& Bailey, 1963: fig. 30) and is synapomorphic for the species of Cnesterodon. Remaining studied taxa lack such process (state 0 ).

Character 70 - Anterior border of second gonactinost: (0) straight; (1) bearing a convex expansion.

The anterior border of second proximal radial of anal fin in adult males of most atherinomorphs fishes is straight (state 0). However, in Priapichthys, Heterandria, Pseudopoecilia, Neoheterandria, Girardinus, Phallichthys, Xenophallus, Poeciliopsis, Carlhubbsia, Pamphorichthys hollandi, Micropoecilia, "Poecilia", and Phallotorynus the anterior border of second gonactinost exhibits a convex expansion in adult males (state 1, Rosen \& Bailey, 1963: fig. 29A). Although this character contributed to the resolution of the present topology, it presented several independent acquisitions and reversals during the history of the Cyprinodontiformes.

Character 71 - Distal portion of second and third gonactinosts (Fig. 16): (0) separate; (1) fused; (2) coalescent only at distal tip, forming an oblong aperture.

In most cyprinodontiform fishes the distal portion of second and third anal-fin proximal radials in adult males is separate (state 0, Fig. 16a). In Alfaro, Priapichthys, Heterandria, Belonesox, Neoheterandria, Girardinus, Phallichthys, Xenophallus, Poeciliopsis, Phalloptychus, Limia, Pamphorichthys, Cnesterodon n. sp. A, Phalloceros n. sp. A, and Phalloceros n. sp. H the distal portion of second and third gonactinost is fused (state 1, Fig. 16b, e). This feature presented several independent acquisitions and reversals during the history of the Cyprinodontiformes.

In Phallotorynus n. sp. A and Phallotorynus n. sp. B these are coalescent only at distal tip, forming an oblong aperture (state 2, Fig. 16c), with is interpreted as a synapomorphy for these two species.

Character 72 - Fusion of second and third anal-fin gonactinosts (Fig. 16a): (0) absent; (1) complete; (2) partial.

In outgroup taxa, Xenodexia, and Micropoecilia sp. second and third gonactinosts are free in adult males (state 0, Fig. 16a). These elements are completed fused (state 1, Fig. 16b) in males of Tomeurus, Alfaro, Priapichthys, Gambusia, Belonesox, Neoheterandria, Phallichthys, Xenophallus, Poeciliopsis, Phalloptychus, Limia, Pamphorichthys hollandi, Phalloceros n. sp. A, and Phalloceros n. sp. H. Remaining taxa studied exhibit second and third gonactinosts partially fused (state 2, Fig. 16c, e). Although this character contributed to the resolution of the present topology, it pre- sented several independent acquisitions and reversals during the history of the Cyprinodontiformes.

Character 73 - Shape of gonactinostal complex (Rauchenberger, 1989: fig. 22 C, D): (0) plate-like; (1) fused into a column.

In most poeciliines the gonactinostal complex is expanded in a laminar plate in the anterior-posterior plane; gonactinosts are spread out in this plate-like spokes in a fan (state 0). Belonesox and Gambusia possess second, third, and fourth gonactinosts fused into a column (state 1). This is interpreted as a synapomorphic for a clade composed by both genera. This feature has been proposed by Rauchenberger (1989).

Character 74 - Distal portion of third and fourth gonactinosts: (0) separate; (1) completely fused; (2) separate, except by tip of gonactinost 3, which is arched backward towards gonactinost 4; (3) completely fused, except by a small notch.

Members of the outgroup, Brachyrhaphis, Priapella, Pseudopoecilia, Neoheterandria, Scolichthys, Girardinus, Phallichthys, Quintana, Carlhubbsia, Xiphophorus, Xenodexia, Limia, Pamphorichthys scalpridens, Micropoecilia sp, Cnesterodon n. sp. A, Cnesterodon n. sp. B, P. jucundus, $P$. victoriae, $P$. fasciolatus, and almost all species of Phalloceros exhibit the distal portion of third and fourth gonactinosts separate in adult males (state 0, Fig. 16a).

In Alfaro, Priapichthys, Gambusia, Belonesox, Xenophallus, Poeciliopsis, Phalloptychus, Poecilia, Pamphorichthys hollandi, Phallotorynus n. sp. A, Phallotorynus n. sp. B, Phalloceros n. sp. D, Phalloceros n. sp. F, Phalloceros n. sp. H, Phalloceros n. sp. Q, and Phalloceros n. sp. J the distal portions of third and fourth gonactinosts are completely fused (state 1, Fig. 16b, c).

Tomeurus, "Poecilia", Micropoecilia branneri, Cnesterodon decemmaculatus, C. hypselurus, $C$. brevirostratus, $C$. septentrionalis, $C$. omorgmatos, and $C$. carnegiei possess the distal portions of third and fourth gonactinosts separate, except by the tip of gonactinost 3, which is arched backward towards gonactinost 4 (state 2, Fig. 16d). Distal portions of third and fourth gonactinosts are completely fused, except by a small notch (state 3 , Fig. 16e) in Heterandria.

Although this character contributed to the resolution of the present topology, it presented several independent acquisitions and reversals during the history of the poeciliines.

Ghedotti (2000) recognized 3 states of this character. We add a fourth state (75-3). This author reported third and fourth proximal anal-fin radials completely fused in Gambusia affinis, Poeciliopsis latidens, and Heterandria formosa and partially fused, forming an oblong opening in Phallichthys amates and Poecilia sphenops.

Character 75 - Lateral flanges on ventral portion of fourth gonactinost (Ghedotti, 2000: fig. 16): (0) absent; (1) present and continuous, without dorsal cleft; (2) present and cleft dorsally forming separate dorsally directed processes. 

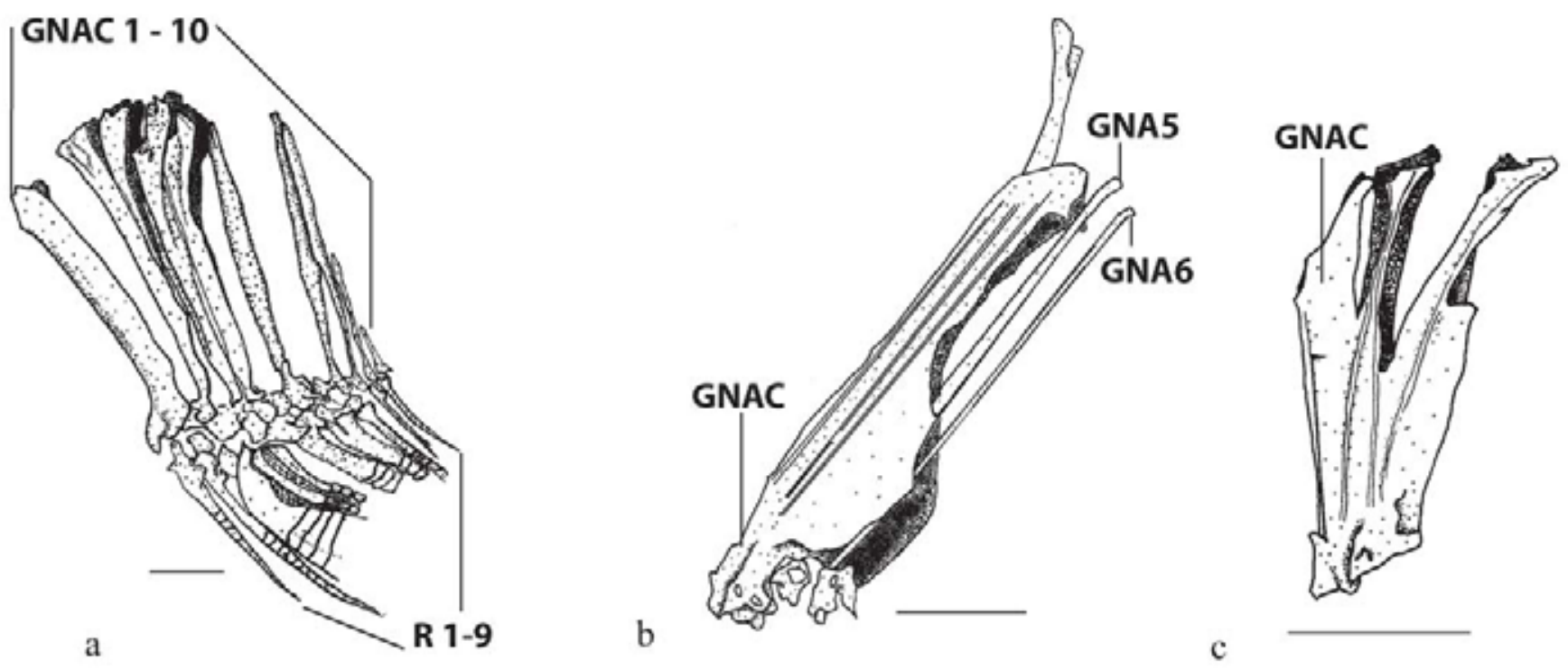

d

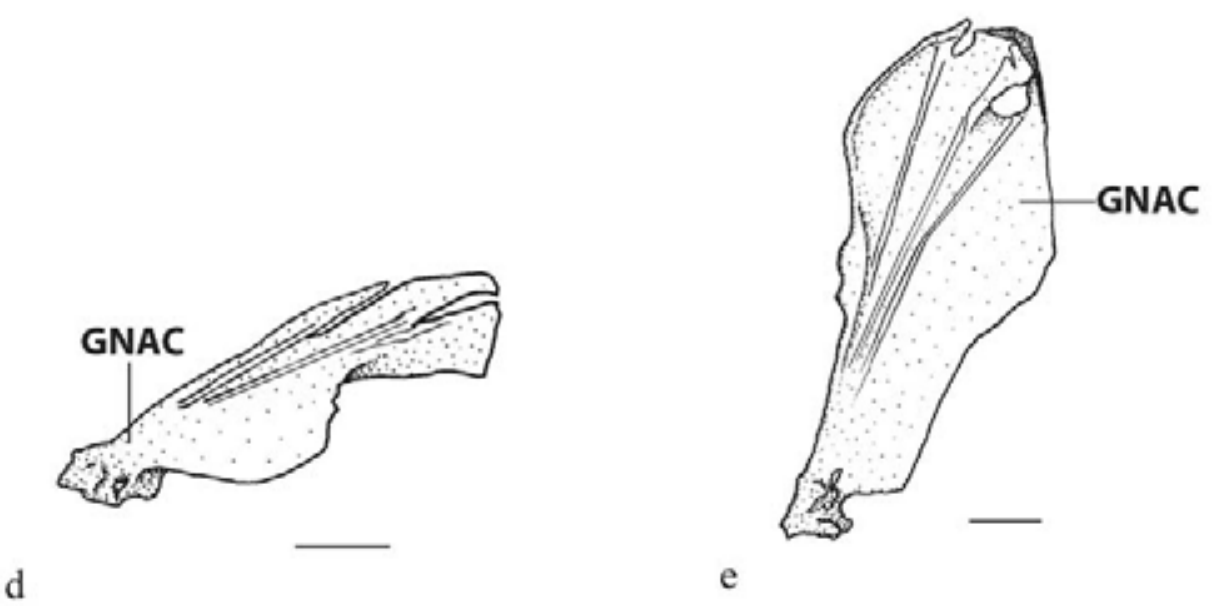

Fig. 16. Gonactinostal complexes. (a) Xenodexia ctenolepis, AMNH 32137; (b) Phalloptychus iheringii, MCP 11054; (c) Phallotorynus n. sp. A, NRM 42823; (d) Cnesterodon brevirostratus, MCP 13950; (e) Heterandria jonesii UMMZ 2109990. $\mathrm{GNA}=$ gonactinost GNAC $=$ gonactinost complex; $\mathrm{R}=$ ray. Scale bar $1 \mathrm{~mm}$.

This character was employed by Ghedotti (2000). Most cyprinodontiforms lack lateral flanges on ventral portion of fourth anal-fin radial in adult males (state 0 ). Lateral flanges on ventral portion of fourth gonactinost are continuous, without dorsal cleft (state 1) in Gambusia and Belonesox and are hypothesized as a synapomorphy uniting both. In Girardinus, Phallotorynus, and Phalloceros lateral flanges are present and cleaved dorsally forming separate dorsally directed processes (state 2). The topology of our strict consensus tree supports the hypothesis that state 2 appeared independently in Girardinus and in the ancestor of Phallotorynus and Phalloceros.

Character 76 - Posteroventral projection of ventral flange of fourth gonactinost (Fig. 17): (0) absent; (1) large; (2) small.

Phallotorynus species are unique among cyprinodontiforms by having a posteroventral projection of ventral flange of fourth gonactinost (Fig. 17). The absence of this structure in remaining cyprinodontiform taxa is consid- ered plesiomorphic (state 0). In Phallotorynus fasciolatus and $P$. victoriae this projection is large (state 1, Fig. 17a). In Phallotorynus jucundus, Phallotorynus n. sp. A, and Phallotorynus n. sp. B the projection is small (state 2; Fig. 17b). The presence of a posteroventral projection of ventral flange of fourth gonactinost is interpreted as synapomorphic for Phallotorynus with a derived size reduction in Phallotorynus jucundus, Phallotorynus n. sp. A, and Phallotorynus n. sp. B.

Character 77 - Fusion of posterior middle radials of anal-fin ( $5^{\text {th }}$ to last) in adult males to respective proximal radials: $(0)$ absent; (1) present.

Posterior median radials of anal-fin ( $5^{\text {th }}$ to last one) in adult males are independent and separate in most atherinomorphs (state 0). Procatopus, Tomeurus, Alfaro, Xenodexia, Poecilia, Limia, Pamphorichthys, Micropoecilia, "Poecilia", and Cnesterodon are unique among cyprinodontiforms by the fusion of posterior median radials of anal-fin ( $5^{\text {th }}$ to last one) 
in adult males to respective proximal radials (gonactinosts of Poeciliinae) (state 1). This derived feature is interpreted as acquired by the ancestor of poeciliines, with a synapomorphic reversal in clade 125 (which comprehends all poeciliines except Tomeurus and Alfaro). Within Clade 125 state 1 is independently acquired by Cnesterodon and by the ancestor of Xenodexia, Poecilia, Limia, Pamphorichthys, Micropoecilia, and "Poecilia" [Clade 104].

Character 78 - Anterior process on base of fifth middle analfin radial in adult males (Fig. 18): (0) absent; (1) pointed and upward directed; (2) hardly developed, and rounded.

The outgroup taxa, Tomeurus, Xenophallus, Poeciliopsis, Pseudopoecilia, Phalloptychus, Carlhubbsia, Xenodexia, Limia, Pamphorichthys, Micropoecilia, "Poecilia", and Phalloceros lack an anterior process on base of fifth middle anal-fin radial in adult males (state 0, Fig. 18a). This process is hardly developed, and round (state 2, Fig. 18c) in Cnesterodon, Brachyrhaphis, and Belonesox. This process is pointed and upward directed (state 1, Fig. 18b) in remaining taxa studied. Although this character contributed to the resolution of the present topology, it presented several independent acquisitions and reversals during the history of the Cyprinodontiformes.

Character 79 - Lateral process on base of fifth and sixth middle anal-fin radial in adult males: (0) absent; (1) large; (2) very large; (3) asymmetrical; (4) minute.

A lateral process on base of fifth and sixth middle anal-fin radial in adult males is absent in the outgroup taxa and in Tomeurus (state 0, Rosen \& Bailey, 1963: fig. 15). In Brachyrhaphis, Priapichthys, Priapella, Heterandria, Pseudopoecilia, Scolichthys, Neoheterandria, Carlhubbsia, Quintana, Xiphophorus, Limia, Micropoecilia, Phalloceros, and Phallotorynus (except Phallotorynus n. sp. B) the lateral process is large (state 1, Rosen \& Bailey, 1963: fig. 29A, B) and in Cnesterodon is even more enlarged (state 2, Rosen \& Bailey, 1963: fig. 30). In Phallichthys, Xenophallus, Poeciliopsis, and Phalloptychus this process is asymmetrical (state 3, Fig. 19; Rosen \& Bailey, 1963: fig. 56). In remaining taxa studied the lateral process on base of fifth and sixth middle anal-fin radial in adult males is minute (state 4, Rosen \& Bailey, 1963: fig. 23).

Character 80 - Asymmetry of middle anal-fin radials 5, 6, and 7 in adult males (Fig. 19) (0) absent; (1) present.

In most cyprinodontiforms middle anal-fin radials 5, 6, and 7 are symmetrical in adult males, with right and left lateral projections similar in shape and size (state 0 ). Middle anal-fin radials 5, 6, and 7 are asymmetrical in adult males, with right lateral projection more compressed and much larger than left one in Phallichthys, Xenophallus, Poeciliopsis, Phalloptychus, and Xenodexia (state 1, Fig. 19). This feature is hypothesized as independently acquired by Xenodexia and in the ancestor of a clade containing Phallichthys, Xenophallus, Poeciliopsis, and Phalloptychus [Clade 113].

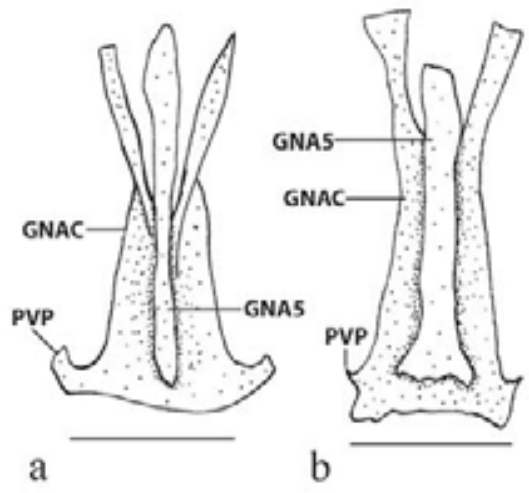

Fig. 17. Posterior view of gonactinostal complex and fifth gonactinost of (a) Phallotorynus victoriae, NRM 42907; (b) Phallotorynus n. sp. A, NRM 42823. GNAC = gonactinost complex; GNA5 = gonactinost 5; $\mathrm{PVP}=$ posteroventral projection of ventral flange. Scale bar $1 \mathrm{~mm}$.

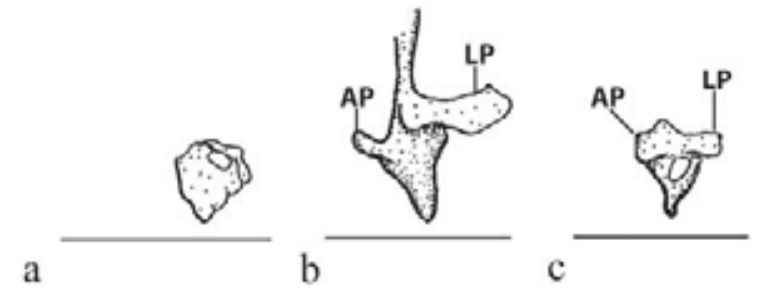

Fig. 18. Fifth mesonost of (a) Phalloptychus iheringii, MCP 11054; (b) Cnesterodon brevirostratus, MCP 13950; (c), Phallotorynus jucundus, $\mathrm{UFPB} 2161 . \mathrm{AP}=$ anterior process; $\mathrm{LP}=$ lateral process. Scale bar $1 \mathrm{~mm}$.

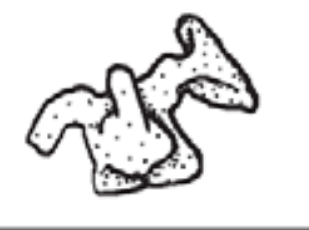

Fig. 19. Posterior view of sixth mesonost of Phalloptychus iheringii, MCP 11054. LLP = left lateral process; RLP = right lateral process; Scale bar $1 \mathrm{~mm}$.

Character 81 - Gonactinost 5: (0) free; (1) fused to complex gonactinost.

Gonactinost 5 is free in almost all poeciliines (state 0 ). In Limia, "Poecilia" reticulata, and Micropoecilia gonactinost 5 is fused to gonactinostal complex (state 1). This condition is interpreted as derived and independently acquired by the aforementioned genera.

Character 82 - Ventral portion of proximal anal-fin radials 6 to 10 in adult males (Ghedotti, 2000: fig. 14): (0) laterally compressed with anterior and posterior flanges; (1) not laterally compressed without anterior and posterior flanges.

Most cyprinodontiforms possess the ventral portion of proximal anal-fin radials 6-10 in adult males laterally compressed, with anterior and posterior flanges (state 0). In poeciliines the ventral portion of gonactinosts 6-10 is not 
laterally compressed, without anterior and posterior flanges (state 1), which is proposed as synapomorphic for the subfamily Poeciliinae. This character has been discussed by Ghedotti (2000).

Character 83 - Eighth anal-fin gonactinost (Rosen \& Bailey, 1963: fig. 53): (0) straight; (1) bearing wing-like lateral projections.

Xenophallus and Priapichthys are unique among poeciliines by eighth gonactinost bearing wing-like lateral projections. This feature is interpreted as apomorphic (state 1) and independently acquired by these two taxa, whereas the absence of this structure in remaining atherinomorph fishes is herein interpreted as plesiomorphic (state 0).

Character 84 - Ninth anal-fin gonactinost (Rosen \& Bailey, 1963: fig. 53): (0) straight; (1) bearing wing-like lateral projections.

Rosen \& Bailey (1963) reported the presence of wing-like projections in Brachyrhaphis, Priapichthys, and Neoheterandria (including Xenophallus) and employed this character as diagnostic (in combination with other characters) for the genera above. Meyer \& Etzel (1996) reported the presence of "plate-like outgrowths" in the ninth gonactinost of Neoheterandria tridentiger (Garman) and in the eighth gonactinost of Xenophallus umbratilis (Meek). These authors stated that the presence of wing-like lateral projections as a "primitive character in poeciliid fishes" (Meyer \& Etzel, 1996: 3), arguing that this condition is very common among poeciliines: "because plate-like outgrowths of the gonactinostal system are found in several taxa" (Meyer \& Etzel, 1996: 3). However, this statement is made in the absence of a cladistic analysis, which prevents the evaluation of character polarity. Besides, the fact that a character state is very common does not guarantee it is the plesiomorphic state.

Brachyrhaphis, Priapichthys, Neoheterandria, and Xenophallus, are unique among poeciliines by the possession of wing-like lateral projections on the ninth gonactinost. The presence of this structure in each of four taxa above is interpreted as apomorphic (state 1) and homoplastic (independently derived). On the other hand, the absence of these wing-like lateral projections in remaining atherinomorphs is viewed as the plesiomorphic condition (state 0 ).

Character 85 - Number of anal-fin rays on males: (0) ten; (1) twelve; (2) eleven; (3) eight; (4) nine; and (5) thirteen or more.

Ghedotti (2000) studied this character, however without discriminating males and females. Fundulus, Scolichthys, Xenophallus, Poeciliopsis, Quintana, Xiphophorus, Poecilia, Limia, "Poecilia", Micropoecilia branneri, Phalloceros n. sp. C, Phalloceros n. sp. D, Phalloceros $\mathrm{n}$. sp. A, Phalloceros n. sp. E, Phalloceros n. sp. U, Phalloceros n. sp. T, Phalloceros n. sp. S, Phalloceros n. sp. I, and Phalloceros $\mathrm{n}$. sp. J exhibit 10 anal-fin rays on males (state 0 ). Males specimens of Cyprinodon and Alfaro possess twelve anal-fin rays (state 1), whereas males specimens of Priapella,
Priapichthys, Heterandria, Gambusia, Belonesox, Girardinus, Phallichthys, Carlhubbsia, and Xenodexia possess eleven anal-fin rays (state 2). Fluviphylax, Tomeurus, Pamphorichthys hollandi, Phalloptychus iheringii, Phallotorynus fasciolatus, and Phallotorynus victoriae present eight anal-fin rays on males (state 3). Nine anal-fin rays (state 4) is found in males of Pseudopoecilia, Neoheterandria, Phalloptychus januarius, Pamphorichthys scalpridens, Micropoecilia sp., Cnesterodon, P. jucundus, Phallotorynus n. sp. A, Phallotorynus n. sp. B, Phalloceros n. sp. G, Phalloceros n. sp. F, Phalloceros n. sp. B, Phalloceros n. sp. V, Phalloceros n. sp. R, Phalloceros n. sp. $\mathrm{N}$, Phalloceros n. sp. O, Phalloceros n. sp. M, Phalloceros n. sp. H, Phalloceros n. sp. Q, and Phalloceros n. sp. L. Male individuals of Aplocheilichthys and Procatopus have 13 or more anal-fin rays (state 5). Although this character contributed to the resolution of the present topology, it presented several independent acquisitions and reversals during the history of the poeciliines.

Character 86 - Anal-fin rays 3, 4, and 5 in adult males (R3, R4, R5): (0) similar to remaining anal-fin rays; (1) modified into a gonopodium.

The presence of a gonopodium formed by modified analfin rays 3,4 , and 5 in adult males has long been used as diagnostic for poeciliines (e.g. Garman, 1895; Eigenmann, 1907; Regan, 1911, 1913; Hubbs, 1924; Parenti, 1981; Ghedotti, 2000).

Anal-fin rays 3, 4, and 5 in adult males are normally developed, i.e. are similar to remaining anal-fin rays in most atherinomorphs (state 0). Poeciliines are unique by the possession of a copulatory structure (gonopodium) formed by modified anal-fin rays 3,4 , and 5 in adult males (state 1 ). This condition is hypothesized as a uniquely derived and unreversed synapomorphy for the subfamily.

Character 87 - Symmetry of anal fin in adult males: (0) present; (1) absent.

Most cyprinodontiform fishes exhibit a symmetrical anal fin in adult males (state 0 ). The anal fin in adult males specimens is asymmetrical in Phallichthys, Xenophallus, Poeciliopsis, and Phalloptychus, Quintana, Carlhubbsia, and Xenodexia (state 1). Rosen \& Bailey (1959) discussed the gonopodium asymmetry of Phalloptychus, Poeciliopsis, Phallichthys, Xenophallus, Carlhubbsia, Quintana, and Girardinus. They believed that characters related to gonopodium folding were highly adaptive and may had evolved independently more than once within the subfamily.

This feature is herein hypothesized as evolving three times in poeciliine history: (1) in the common and exclusive ancestor of Phallichthys, Xenophallus, Poeciliopsis, and Phalloptychus [Clade 113]; (2) in the common and exclusive ancestor of Quintana + Carlhubbsia [Clade 109]; (3) in Xenodexia.

Character 88 - Palp (membranous appendix) in subdistal segments of R3 (Rosen \& Bailey, 1963: fig. 25; Rodriguez, 1997: fig. 5 C-G): (0) absent; (1) present. 
Most cyprinodontiforms do not exhibit a palp in subdistal segments of R3 (state 0), whereas this structure is present (state 1) in some poeciliids.

Rosen \& Bailey (1963) used the presence of a palp in Alfaro and Poecilia as evidence that Alfaro should be placed in the tribe Poeciliini. Rodriguez (1997) suggested that the presence of a palp was independently derived in Alfaro and in the ancestor of a clade including Poecilia, Pamphorichthys, and Limia. Ghedotti (2000) reported the presence of a palp in Alfaro and Poecilia. Among the taxa studied, a palp was observed in Alfaro, Poecilia, Limia, Pamphorichthys, Micropoecilia, and "Poecilia". Our results support the hypothesis that a palp in subdistal segments of R3 was independently derived in Alfaro and the common and exclusive ancestor of a clade including Poecilia, Limia, Pamphorichthys, Micropoecilia, and "Poecilia".

Character 89 - V-shaped ventral projection at distal portion of R3 (Rosen \& Bailey, 1963: fig. 31A): (0) absent; (1) present.

Phallotorynus species are unique among cyprinodontiforms by the possession of a V-shaped ventral projection at distal portion of R3. This condition is hypothesized as apomorphic (state 1) and exclusively shared by Phallotorynus species.

Character 90 - Pedicel in R3 united to R4 (Rosen \& Bailey, 1963: fig. 31A, B, C, D, F, G): (0) absent; (1) present.

Most cyprinodontiform fishes lack a pedicel in R3 united to R4 (state 0). Phallotorynus, Phalloceros, and Cnesterodon species are unique among cyprinodontiforms by the possession of a pedicel in R3 united to R4 (state 1). This condition is hypothesized as a synapomorphy for the tribe Cnesterodontini.

Character 91 - Pedicel at tip of R3 (Rosen \& Bailey, 1963: fig. 31A, B, C, D, F, G): (0) absent; (1) present.

The presence of a pedicle at tip of R3 long been reported by different authors (Hubbs, 1924; Rosen \& Bailey, 1963). Phallotorynus, Phalloceros and Cnesterodon species are unique among cyprinodontiforms by the possession of a pedicel at tip of R3 (state 1). This condition is hypothesized as a synapomorphy for the tribe Cnesterodontini.

Character 92 - Membranous appendix at tip of R3 (Rosen \& Bailey, 1963: fig. 31 A, B, C, D, F, G): (0) absent; (1) present.

The presence of a membranous appendix at tip of R3 long been reported by different authors (Hubbs, 1924; Rosen \& Bailey, 1963; Ghedotti, 2000). Phallotorynus, Phalloceros, and Cnesterodon species are unique among cyprinodontiforms by the possession of a membranous appendix at tip of R3 (state 1). This condition is hypothesized as a synapomorphy for the tribe Cnesterodontini.

Character 93 - Paired appendix at tip of R3 (Rosen \& Bailey, 1963: fig. 31 C, D): (0) absent; (1) present.
Paired appendix at tip of R3 has long been reported as diagnostic for Phalloceros (e.g. Eigenmann, 1907; Rosen \& Bailey, 1963) Phalloceros species are unique among cyprinodontiforms by the possession of a paired appendix at tip of R3 (state 1). This condition is hypothesized as synapomorphic for the genus Phalloceros.

Character 94 - Hooks on paired gonopodial appendix (at least the right one) (Figs. 20-22): (0) absent; (1) large and sicklelike; (2) not sickle-like.

Among Phalloceros species, Phalloceros n. sp. B, Phalloceros n. sp. D, Phalloceros n. sp. A, Phalloceros n. sp. C, and Phalloceros caudimaculatus lack hooks on paired gonopodial appendix (state 0; Fig. 20). Hooks are large and sickle-like (state 1; Fig. 21) in Phalloceros n. sp. E, Phalloceros n. sp. G, and Phalloceros n. sp. F. Hooks are not sickle-like in remaining species of Phalloceros (state 2; Fig. 22; Rosen \& Bailey, 1963: fig. 31 D). State 1 is herein interpreted as synapomorphic for a clade composed of Phalloceros $\mathrm{n}$. sp. E, Phalloceros n. sp. G, and Phalloceros n. sp. F [Clade 81]. State 2 is hypothesized as synapomorphic for the clade [Phalloceros $\mathrm{n}$. sp. U + Phalloceros $\mathrm{n}$. sp. T + Phalloceros $\mathrm{n}$. sp. S + Phalloceros n. sp. V + Phalloceros n. sp. B + Phalloceros n. sp. $\mathrm{N}+$ Phalloceros $\mathrm{n}$. sp. $\mathrm{R}+$ Phalloceros $\mathrm{n}$. sp. I + Phalloceros n. sp. O + Phalloceros n. sp. P + Phalloceros n. sp. $\mathrm{M}+$ Phalloceros $\mathrm{n}$. $\mathrm{sp}$. $\mathrm{H}+$ Phalloceros $\mathrm{n}$. sp. Q + Phalloceros n. sp. J + Phalloceros n. sp. L] [Clade 82]. A reversal to state 0 occurred in Phalloceros n. sp. B.

Character 95 - Similarity of the halves of gonopodial paired appendix: (0) similar to each other; (1) different from each other; right half wider than left one.

In most species of Phalloceros the halves of gonopodial paired appendix are similar to each other (state 0; Fig. 20, 21; Rosen \& Bailey, 1963: fig. 31 D). In Phalloceros n. sp. O, Phalloceros n. sp. P, Phalloceros n. sp. H, Phalloceros n. sp. Q, Phalloceros n. sp. J, and Phalloceros n. sp. L halves of gonopodial paired appendix are different from each other; right half is wider than left one (state 1; Fig. 22), which is interpreted as synapomorphic for the ancestor of a clade containing these species plus Phalloceros n. sp. M, with a reversal in the latter.

Character 96 - Shape of the halves of gonopodial paired appendix: (0) not sickle-like, with a medium corner; (1) sicklelike, lacking a medium corner; (2) straight and perpendicular to R3.

Phalloceros caudimaculatus, Phalloceros n. sp. B, Phalloceros n. sp. D, Phalloceros n. sp. A, Phalloceros n. sp. C, Phalloceros n. sp. U, Phalloceros n. sp. T, Phalloceros n. sp. $\mathrm{S}$, Phalloceros n. sp. V, Phalloceros n. sp. N, Phalloceros n. sp. $\mathrm{R}$, Phalloceros n. sp. I, and Phalloceros n. sp. B possess halves of gonopodial paired appendix not sickle-like, with a medium corner (state 0; Rosen \& Bailey, 1963: fig. 31 C, D). Halves are sickle-like, lacking a medium corner (state 1; Figs. 21, 22) in Phalloceros n. sp. E, Phalloceros n. sp. G, Phalloceros n. sp. F, 
Phalloceros n. sp. O, Phalloceros n. sp. P, Phalloceros n. sp. M, Phalloceros n. sp. H, Phalloceros n. sp. Q, and Phalloceros n. sp. L. In Phalloceros n. sp. J halves of gonopodial paired appendix are straight and perpendicular to R3 (Fig. 20).

State 1 is herein interpreted as synapomorphic and independently acquired for a clade composed of Phalloceros $\mathrm{n}$. sp. E + Phalloceros n. sp. G + Phalloceros n. sp. F [Clade 81] and for the clade [Phalloceros $\mathrm{n}$. sp. $\mathrm{O}+$ Phalloceros n. sp. $\mathrm{P}$ + Phalloceros n. sp. $\mathrm{M}+$ Phalloceros $\mathrm{n}$. $\mathrm{sp} . \mathrm{H}+$ Phalloceros n. sp. Q + Phalloceros n. sp. J + Phalloceros n. sp. L] [Clade 74]. State 2 is hypothesized as autapomorphic for Phalloceros n. sp. J.

Character 97 - Hooks large directed downward and located in the corner of gonopodial appendix: (0) absent; (1) present.

In most Phalloceros species hooks are small, anterodorsally directed and located nearer the base of the gonopodial appendix (Fig. 21). Phalloceros n. sp. I, Phalloceros n. sp. R, and Phalloceros n. sp. N, are unique among poeciliines by the possession of large hooks, downward directed and located in the corner of the gonopodial appendix (Fig. 23). This feature is hypothesized as synapomorphic for these three species.

Character 98 - Presence of hooks on gonopodial paired appendix Character 99 - Presence of hooks on gonopodial paired appendix: (0) absent; (1) present in both halves; (2) present only on left half.

Among Phalloceros species, Phalloceros n. sp. B, Phalloceros n. sp. D, Phalloceros n. sp. A, Phalloceros n. sp. C, and Phalloceros caudimaculatus lack hooks on paired gonopodial appendix (state 0; Fig. 20). Hooks are present in both halves of gonopodial appendix (state 1; Figs. 21, 24) in Phalloceros n. sp. E, Phalloceros n. sp. G, Phalloceros n. sp. F, Phalloceros n. sp. U, Phalloceros n. sp. T, Phalloceros n. sp. S, Phalloceros n. sp. V, Phalloceros n. sp. I, Phalloceros n. sp. N, and Phalloceros n. sp. R. Hooks are present only on left half (state 2; Fig. 22) in remaining species of Phalloceros.

State 1 is herein interpreted as synapomorphic for the clade [Phalloceros n. sp. F + Phalloceros n. sp. G + Phalloceros n. sp. E + Phalloceros n. sp. U + Phalloceros $\mathrm{n}$. sp. $\mathrm{T}+$ Phalloceros $\mathrm{n}$. sp. $\mathrm{S}+$ Phalloceros $\mathrm{n}$. sp. $\mathrm{V}+$ Phalloceros n. sp. B + Phalloceros n. sp. $\mathrm{N}+$ Phalloceros $\mathrm{n}$. sp. $\mathrm{R}+$ Phalloceros n. sp. I + Phalloceros n. sp. $\mathrm{O}+$ Phalloceros n. sp. $\mathrm{P}+$ Phalloceros $\mathrm{n}$. sp. $\mathrm{M}+$ Phalloceros $\mathrm{n}$. sp. $\mathrm{H}+$ Phalloceros n. sp. Q + Phalloceros n. sp. J + Phalloceros n. sp. L] [Clade 83]. A reversal to state 0 appeared in Phalloceros n. sp. B. State 2 is hypothesized as synapomorphic for the clade [Phalloceros n. sp. O+ Phalloceros n. sp. $\mathrm{P}+$ Phalloceros $\mathrm{n} . \mathrm{sp} . \mathrm{M}+$ Phalloceros $\mathrm{n}$. sp. $\mathrm{H}+$ Phalloceros n. sp. Q + Phalloceros n. sp. J + Phalloceros n. sp. L] [Clade 74].

Character 99 - Minute paired terminal hook on R3 (Rosen \& Bailey, 1959: fig. 7): (0) absent; (1) present.
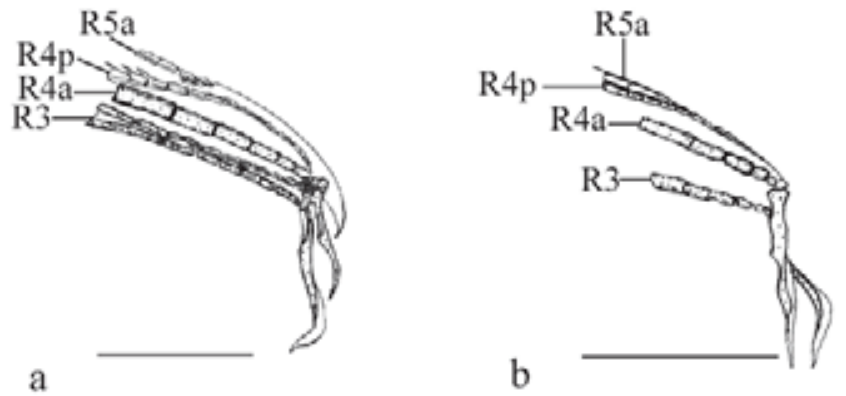

Fig. 20. Gonopodium tip of Phalloceros n. sp. J, MCP 29270. (a) ventrolateral view; (b) lateral view. Scale bar $1 \mathrm{~mm}$.
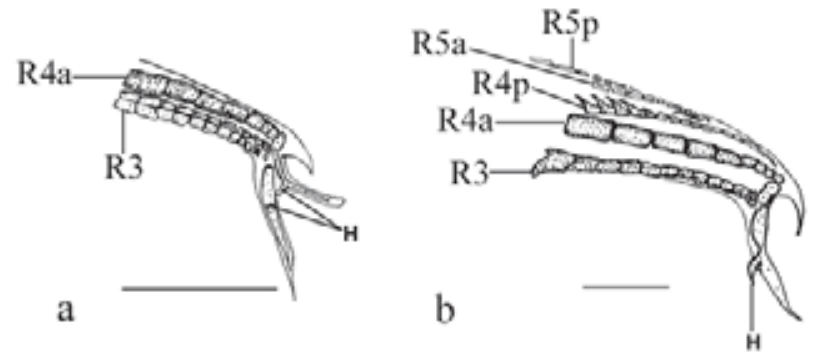

Fig. 21. Gonopodium tip of Phalloceros n. sp. F, MCP30572. (a) ventrolateral view; (b) lateral view. $\mathrm{H}=$ hook. Scale bar $1 \mathrm{~mm}$.

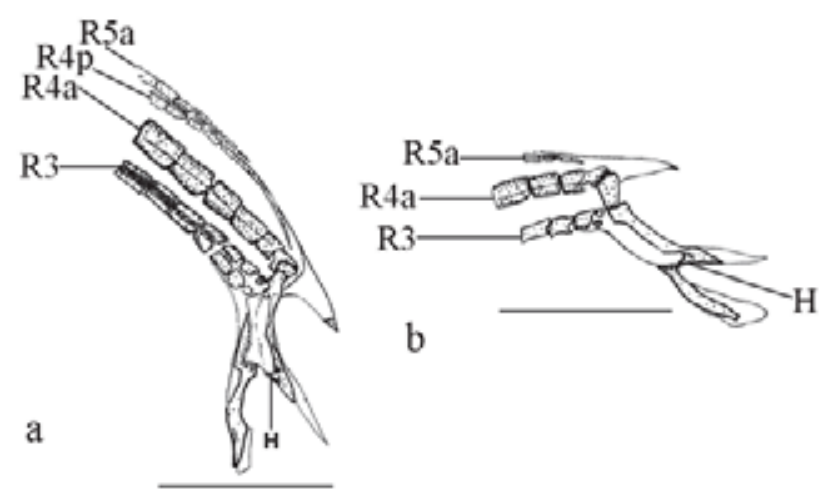

Fig. 22. Gonopodium tip of Phalloceros n. sp. L, MCP 20579. (a) ventrolateral view; (b) lateral view. $\mathrm{H}=$ hook. Scale bar $1 \mathrm{~mm}$.

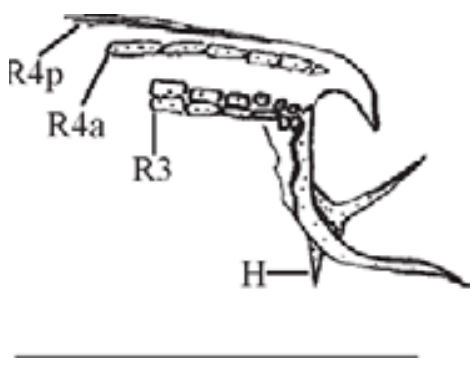

Fig. 23. Gonopodium tip of Phalloceros n. sp. R, holotype, MZUSP 79669. $\mathrm{H}=$ hook. Scale bar $1 \mathrm{~mm}$. 
Rosen \& Bailey (1959) suggested that Girardinus and Quintana were closely related and share a homologous minute paired terminal hook on R3. However our results support that Girardinus and Quintana are not closely related and that the possession of a minute paired terminal hook on R3 was independently acquired by both taxa. Thus this derived feature is regarded as non-homologous in Girardinus and Quintana.

Character 100 - Trowel-like appendix at tip of R3 (Rosen \& Bailey, 1963: fig. 31 A, B): (0) absent; (1) present.

Rosen \& Bailey (1963) reported a trowel-like appendix at tip of R3 as synapomorphic for Phallotorynus species. Phallotorynus is unique among cyprinodontiforms by the possession of a trowel-like appendix at tip of R3. This condition (state 1) is hypothesized as a synapomorphy for the genus, while the absence of such structure in remaining cyprinodontiform fishes is interpreted as plesiomorphic (state 0$)$.

Character 101 - Unpaired appendix at tip of R3 (Rosen \& Bailey, 1963: fig. $31 \mathrm{~F}, \mathrm{G})$ : (0) absent; (1) present.

Unpaired appendix at tip of $\mathrm{R} 3$ was suggested as a putative synapomorphy for Cnesterodon species by Rosen \& Bailey (1963) and Rose \& Costa (1993). Cnesterodon species are unique among cyprinodontiforms by the possession of an unpaired appendix at tip of R3. The possession of this structure (state 1) is interpreted as synapomorphic for Cnesterodon.

Character 102 - Large membrane on pedicel of gonopodium: (0) absent; (1) present:

Phallotorynus species are unique among cyprinodontiforms by the possession of a large membrane on pedicel of the gonopodium. This condition is herein hypothesized as a synapomorphy for the genus Phallotorynus (state 1).

Character 103 - Constriction of unpaired appendix of gonopodium: (0) absent; (1) present.

Cnesterodon decemmaculatus Cnesterodon $\mathrm{n}$. sp. B, and Cnesterodon raddai lack a constriction on unpaired appendix of the gonopodium (state 0; Rosa \& Costa, 1993: fig. 10); whereas Cnesterodon n. sp. A, C. hypselurus, $C$. septentrionalis, C. carnegiei, and C. omorgmatos possess this feature (state 1; Rosa \& Costa, 1993: fig. 12, 13); which is interpreted as a synapomorphy for a clade containing these species plus C. brevirostratus [Clade 103]. Cnesterodon brevirostratus is polymorphic and was coded "-.".

Character 104-Shape of the trowel-like appendix at tip of R3: (0) absent; (1) narrow and elongate; (2) wide and short.

Phallotorynus species are unique among cyprinodontiforms by the possession of a trowel-like appendix at tip of R3. In the light of the present evidence, the absence of this appendix in cyprinodontiform fishes other than Phallotorynus is interpreted as plesiomorphic (state 0). In Phallotorynus victoriae, P. jucundus, and Phallotorynus $\mathrm{n}$. sp. B the trowel-like appendix is narrow and elongate (state 1;
Figs. 24, 27). In Phallotorynus n. sp. A the appendix is wide and short (state 2; Fig. 25). The presence of a trowel-like appendix at tip of R3 is interpreted as synapomorphic for Phallotorynus with a derived widening and reduction in length in Phallotorynus n. sp. A. Phallotorynus fasciolatus was coded "?" for character state could not be checked due to poor condition of the material studied.

Character 105 - Lateral processes on the trowel-like appendix: (0) small; (1) large.

Phallotorynus victoriae, Phallotorynus n. sp. A, and Phallotorynus $\mathrm{n}$. sp. B possess small lateral processes on the trowel-like appendix (state 0; Figs. 25, 27). Phallotorynus jucundus presents large lateral processes (state 1; Fig. 24), and this feature is interpreted as autapomorphic for $P$. jucundus. Phallotorynus fasciolatus was coded "?" for character state could not be checked due to poor condition of the material studied.

Character 106 - Profile of lateral border of left and right halves of trowel-like appendix: (0) straight; (1) concave.

Phallotorynus victoriae, Phallotorynus jucundus, and Phallotorynus n. sp. B possess the profile of lateral border of left and right halves of trowel-like appendix straight (state 0 ; Figs. 24, 27). Phallotorynus n. sp. A presents a concave profile (state 1; Fig. 25), and this feature is interpreted as autapomorphic for Phallotorynus n. sp. A. Phallotorynus fasciolatus was coded "?" for character state could not be checked due to poor condition of the material studied.

Character 107 - Level of separation/union of left and right halves of the trowel-like appendix: (0) halves separate by a gap along two thirds of its extension; (1) halves united along its whole extension; (2) halves separate along approximately five sixths of its whole extension.

In Phallotorynus victoriae and Phallotorynus n. sp. B the halves of trowel-like appendix are separate by a gap along two thirds of its extension (state 0; Fig. 26). In Phallotorynus jucundus halves are united along its full extension (state 1; Fig. 24). Phallotorynus n. sp. A presents halves separate along approximately five sixths of its whole extension (state 2; Fig. 25). Phallotorynus species are unique among cyprinodontiforms by the possession of a trowel-like appendix at tip of R3. States 1 and 2 are interpreted as autapomorphic for Phallotorynus jucundus and Phallotorynus n. sp. A, respectively.

Character 108 - Spines on subdistal segments of R3: (0) absent; (1) square and antrorse or directed downwards; (2) retrorse.

Among studied taxa, Tomeurus, Alfaro, Brachyrhaphis, Priapichthys, Priapella, Heterandria, Belonesox, and Xenodexia exhibit squared, antrorse or downward directed spines on subdistal segments of R3 (state 1, Rosen \& Bailey, 1963: fig. 25 A, C, H). In Xiphophorus, "Poecilia", and Micropoecilia these spines are retrorse (state 2, Rosen \& Bailey, 1963: fig. 25 B, D). In remaining studied taxa these 
structures are absent (state 0, Rosen \& Bailey, 1963: fig. 25 F). Our results support state 1 as a synapomorphy for Poeciliinae with a reversal to state 0 in the base of clade 119 . Within this clade a change $0>2$ occurs at node 108; a reversal to state 1 appeared in Xenodexia, and two independent reversals took place in both Limia and Pamphorichthys.

Character 109 - Lateral wings on segments of R3: (0) absent; (1) symmetrical; (2) asymmetrical.

Carlhubbsia, Xiphophorus, Xenodexia, Poecilia, Limia, Pamphorichthys, Micropoecilia, and "Poecilia" are unique among poeciliines by the possession of lateral wings on segments of R3. Wings are asymmetrical in Carlhubbsia (state 2; Rosen \& Bailey, 1959: fig. 3D, 10). Xiphophorus, Xenodexia, Poecilia, Limia, Pamphorichthys, Micropoecilia, and "Poecilia" possess symmetrical lateral wings on segments of R3 (state 1, Rosen \& Bailey, 1963: fig. 25B). According to the present hypothesis of relationships State 2 is hypothesized as autapomorphic for Carlhubbsia, whereas state 2 is synapomorphic for a clade composed of Xiphophorus, Xenodexia, Poecilia, Limia, Pamphorichthys, Micropoecilia, and "Poecilia" [Clade 108].

Character 110 - Membranous tip anterior to R4 and R5: (0) absent; (1) curved downwards; (2) straight.

Most cyprinodontiforms lack a membranous tip anterior to R4 and R5 (state 0). Heterandria, Limia, Cnesterodon species except $C$. brevirostratus, Phallotorynus and Phalloceros are unique among poeciliines by the presence of a membranous tip anterior to R4 and R5. This membranous tip is curved downwards (state 1, Rosen \& Bailey, 1963: fig. 31 C, D, F, G) in Heterandria, Limia, Cnesterodon species except $C$. brevirostratus, and in Phalloceros. In Phallotorynus it is straight (state 2, Rosen \& Bailey, 1963: fig. 31 A). According to the present hypothesis state 1 has appeared independently in Heterandria, Limia, and in the ancestor of Cnesterodon, Phallotorynus and Phalloceros Clade 111], with a reversal in C. decemmaculatus. State 2 is interpreted as synapomorphic for Phallotorynus.

Character 111 - Size of membranous tip anterior to R4 and R5: (0) absent; (1) small; (2) reduced; (3) large.

Most cyprinodontiform fishes lack a membranous tip anterior to R4 and R5 (state 0, Rosen \& Bailey, 1963: fig. 39). Heterandria, Limia, Cnesterodon except C. decemmaculatus, Phallotorynus jucundus, and P. victoriae possess a small membranous tip anterior to R4 and R5 (state 1, Rosen \& Bailey, 1963: fig. 31 F, G). This membrane is very reduced in Phallotorynus n. sp. A, and Phallotorynus n. sp. B (state 2, Rosen \& Bailey, 1963: fig. 31 A) and enlarged in Phalloceros species (state 3, Rosen \& Bailey, 1963: fig. 31 D).

The present phylogenetic study support the hypothesis that state 1 was independently acquired by Heterandria, Limia, and by the ancestor of Cnesterodon, Phallotorynus, and Phalloceros, with a reversal to state 0 in $C$. decemmaculatus. State 2 is interpreted as synapomorphic for

Phallotorynus n. sp. A, and Phallotorynus n. sp. B, whereas state 3 is interpreted as synapomorphic for Phalloceros species with a reversal in Phalloceros n. sp. D.

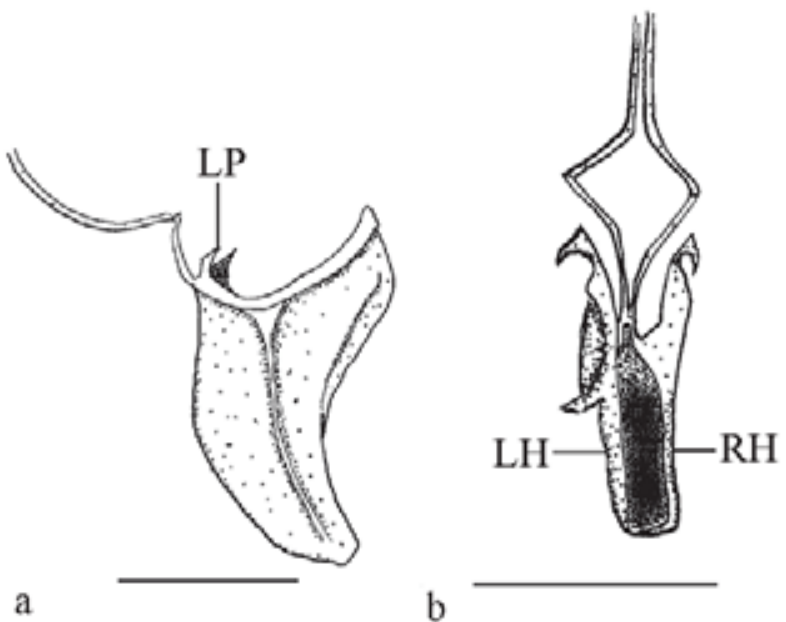

a

Fig. 24. Gonopodium appendix of Phallotorynus jucundus, MCP 25415, (a) lateral view; (b) dorsal view. LP = lateral process; $\mathrm{LH}=$ left half; $\mathrm{RH}=$ right half. Scale bar $1 \mathrm{~mm}$.

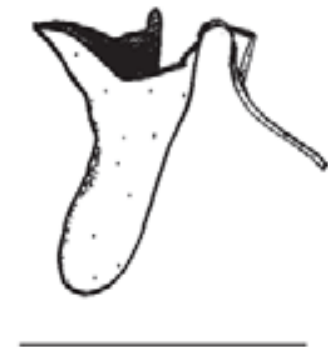

a

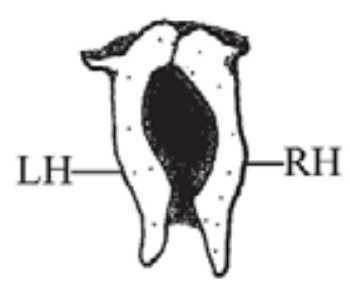

b
Fig. 25. Gonopodium appendix of Phallotorynus n. sp. A, NRM 42823, (a) lateral view; (b) dorsal view. LH = left half; $\mathrm{RH}=$ right half.Scale bar $1 \mathrm{~mm}$.

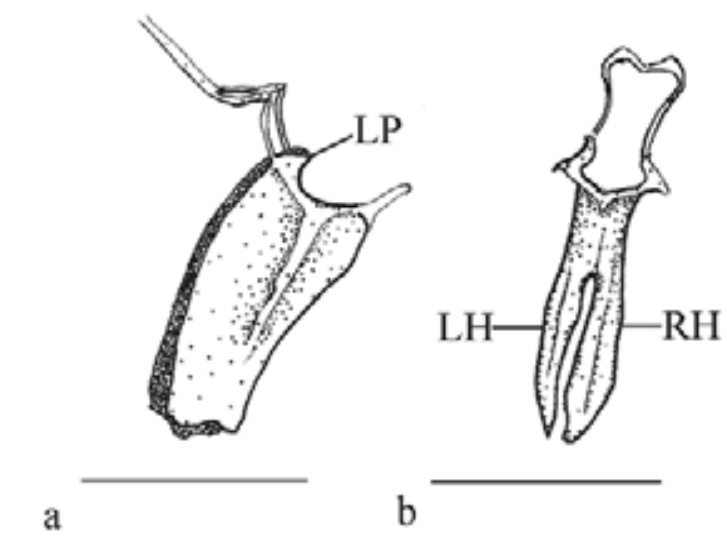

Fig. 26. Gonopodium appendix of Phallotorynus victoriae, NRM 42907, (a) lateral view; (b) dorsal view. LP = lateral process; $\mathrm{LH}=$ left half; $\mathrm{RH}=$ right half. Scale bar $1 \mathrm{~mm}$. 
Character 112 - R5a, R5p, R4p, R4a directed upwards (Rauchenberger, 1989: fig. 23): (0) absent; (1) present.

Rauchenberger (1989) reported R5a, R5p, R4p, R4a directed upwards as a synapomorphy uniting Brachyrhaphis, Gambusia, and Belonesox. However, our phylogenetic framework support this derived feature as independently acquired by Brachyrhaphis and by the ancestor of Gambusia and Belonesox.

Character 113 - Ventral projection of R4a towards R3 (Rauchenberger, 1989: fig. 20; 38): (0) absent; (1) present.

Rauchenberger (1989) reported a ventral projection of $\mathrm{R} 4 \mathrm{a}$ towards R3 as an autapomorphy for Gambusia. However, following the present phylogeny, this derived feature is also present and is hypothesized as synapomorphic for Scolichthys + Neoheterandria [Clade 114]. The presence of this character state in Gambusia is interpreted as homoplastic.

Character 114 - Number of series of subdistal retrorse spines on R4p: (0) zero; (1) one; (2) two.

Members of the outgroup, Tomeurus, Alfaro, Xenophallus, and Xenodexia lack subdistal retrorse spines on R4p (state 0 ). Almost all remaining studied taxa possess at least one series of subdistal retrorse spines on R4p. Xiphophorus and Pamphorichthys scalpridens exhibit two series. State 1 is herein proposed as synapomorphic for a clade comprising all poeciliines except Alfaro and Tomeurus [Clade 125]. Two subsequent independent reversals took place: (1) in Xenophallus and (2) in Xenodexia. The presence of two series of subdistal retrorse spines on R4p in Xiphophorus and Pamphorichthys scalpridens is interpreted as homoplastic.

Character 115 - Depth of distal segments of R4p posterior to serrae (Rodriguez, 1997; Fig. 5f, g): (0) wider than deep; (1) deeper than wide.

In most poeciliines distal segments of R4p posterior to serrae are wider than deep (state 0). Rodriguez (1997) proposed distal segments of R4p posterior to serrae deeper than wide (state 1) as a synapomorphy uniting Limia and Pamphorichthys. This was confirmed herein. Additionally, this feature was also observed to be present in Xenodexia. Our results support the assumption of this derived condition as synapomorphic for a clade containing Xenodexia, Poecilia, Limia, Pamphorichthys, Micropoecilia, and "Poecilia" Clade [104], with two reversals: (1) in Poecilia and (2) in Micropoecilia, and "Poecilia" clade [Clade 87].

Character 116 - Number of subdistal retrorse spines on R4p: (0) zero; (1) eight or more; (2) four to seven.

Among studied taxa, members of the outgroup, Alfaro, Tomeurus, Xenodexia, and Xenophallus lack subdistal retrorse spines on R4p (state 0). Gambusia, Belonesox, Carlhubbsia, Micropoecilia, "Poecilia", Cnesterodon, and Phallotorynus possess four to seven subdistal retrorse spines on R4p (state 2). Remaining studied taxa exhibit eight or more spines (state 1). Global parsimony of character states support the following sequence of evolutive suppositions: (1) state 1 is synapomorphic for Clade 125; (2) state 2 appeared independently in: (a) the ancestor of Gambusia and Belonesox; (b) the ancestor of Cnesterodon, Phalloceros and Phallotorynus, with a reversal to state 1 in Phalloceros; (c) the ancestor of "Poecilia" and Micropoecilia; and (d) in Carlhubbsia; (3) reversals to state 0 occurred in Xenodexia, and Xenophallus.

Character 117 - Short, dorsal protuberance close to base of R4p: (0) absent; (1) present.

Phalloptychus species are unique among cyprinodontiforms by the possession of a short, dorsal protuberance close to base of R4p (Fig. 27). Our phylogenetic analysis supports the hypothesis that this feature represents a synapomorphy for Phalloptychus species (state 1).

Character 118 - Elongate, dorsal protuberance just behind retrorse spines series of R4p (Rosen, 1979: fig. 6, 26): (0) absent; (1) present.

An elongate, dorsal protuberance just behind retrorse spines series of R4p (state 1, Rosen, 1979: fig. 6, 26) in present in Priapella, Heterandria, Girardinus, Phallichthys, Quintana, and Phalloceros. Remaining cyprinodontiforms lack this structure. The phylogenetic analysis supports assuming the absence of such protuberance as plesiomorphic (state 0 ) and its presence as apomorphic (state 1). The presence of this protuberance is herein interpreted as synapomorphic for the members of Clade 123, with subsequent reversals at nodes 120,110 and 115. Within Clade 115, Quintana and Phalloceros independently reacquired state 1 condition.

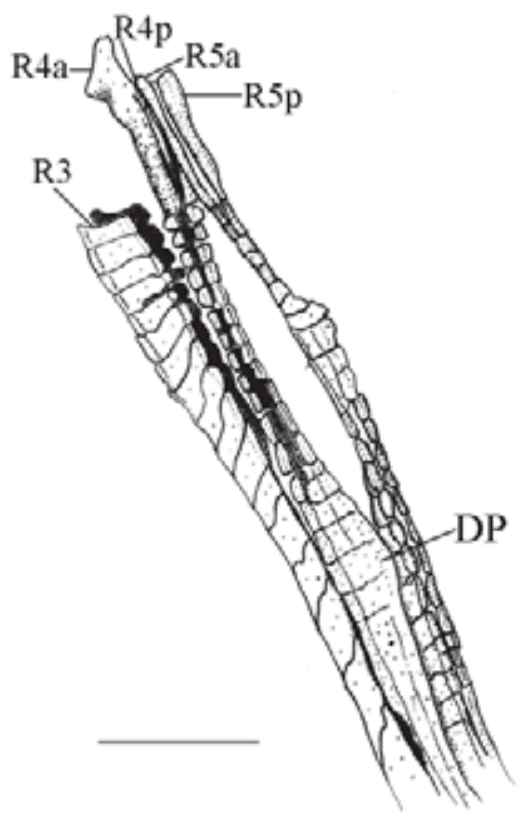

Fig. 27. Base of gonopodium of Phalloptychus iheringii, MCP 11054. DP = dorsal protuberance. Scale bar $1 \mathrm{~mm}$. 
Character 119 - Keel on posterior ventral surface of R5 formed by the projection of R5 toward R4p (Rodriguez, 1997: fig. 5 F): (0) absent; (1) present.

Rodriguez (1997) reported a keel on posterior ventral surface of R5 formed by the projection of R5 toward R4p as synapomorphic for a clade comprising Poecilia, Pamphorichthys, and Limia. We observed this keel in these taxa as well as in Xenodexia. Our phylogenetic framework supports the absence of this keel in most cyprinodontiforms as plesiomorphic (state 0), and its presence as apomorphic (state 1). Thus, the presence of such keel is interpreted as a synapomorphy for a clade embracing Xenodexia, Poecilia, Limia, Pamphorichthys, Micropoecilia, and "Poecilia" [Clade 104] with a reversal in Micropoecilia + "Poecilia" clade.

Character 120 - R5 (Rodriguez, 1997: fig. 5F): (0) not bending into R4; (1) bending into R4.

Rodriguez (1997) stated that Limia is unique among poeciliines by the R5 bending into R4, which was confirmed by our observations. Therefore it is herein considered a synapomorphy for Limia species.

Character 121 - Groove dorsal to R5: (0) narrow or absent; (1) present and wide.

Xenodexia, Poecilia, Limia, Pamphorichthys, Micropoecilia, and "Poecilia" share the presence of a wide groove dorsal to R5. Our phylogenetic framework supports the absence of this groove in most cyprinodontiforms as plesiomorphic (state 0), and its presence as apomorphic (state 1). Thus, the presence of a groove dorsal to R5 is interpreted as a uniquely derived and unreversed synapomorphy for a clade containing Xenodexia, Poecilia, Limia, Pamphorichthys, Micropoecilia, and "Poecilia" [Clade 104] in the light of present evidence.

Character 122 - Distal segment at tip of R5a: (0) normal; (1) transformed in retrorse triangular spine; (2) hook-like.

Rosa \& Costa (1993) suggested the distal segment at tip of R5a modified into a retrorse triangular spine as a putative synapomorphy for Cnesterodon species, whereas Rauchenberger (1989) recognized a hook on tip of R5a as a synapomorphy shared by Gambusia and Belonesox. In most cyprinodontiforms, the distal segment at tip of R5a is similar in shape to remaining segments (state 0). Cnesterodon spe- cies are unique among poeciliines by having the distal segment at tip of $\mathrm{R} 5 \mathrm{a}$ modified into a retrorse triangular spine (state 1; Ghedotti, 2000: fig. 15A), which is herein hypothesized as synapomorphic for this genus. In Gambusia and Xiphophorus this segment is modified into a hook (state 2; Rauchenberger, 1989: fig. 20). However, following our hypothesis of relationships, these derived features are interpreted as independently acquired in Gambusia and Xiphophorus.

Character 123 - Hook on R5a contacting the segments of R4p (Rauchenberger, 1989: fig. 20, 23): (0) absent; (1) present.

Rauchenberger (1989) proposed the presence a hook on R5a contacting the segments of $4 \mathrm{p}$ as a synapomorphy uniting Gambusia and Belonesox. We have confirmed this and also observed this derived feature in Xiphophorus. Thus, the presence of a hook on 5a contacting the segments of $\mathrm{R} 4 \mathrm{p}$ is interpreted as independent acquisitions by Xiphophorus and by the ancestor of Gambusia and Belonesox.

Character 124 - Dorsal expansion of R5p (Fig. 28): (0) absent; (1) present.

Rosa \& Costa (1993) suggested the dorsal expansion of R5p as a putative synapomorphy for Cnesterodon species. However this feature is shared by Tomeurus, Heterandria, Pseudopoecilia, Neoheterandria, Scolichthys, Xenodexia, and Cnesterodon (Fig. 28). This structure is absent in remaining cyprinodontiform fishes. Our phylogenetic framework supports the absence of this expansion in most cyprinodontiforms as plesiomorphic (state 0), and its presence as apomorphic (state 1). According to the present hypothesis, this derived feature is independently acquired by Tomeurus, Heterandria, the ancestor of [Pseudopoecilia + Neoheterandria + Scolichthys], Xenodexia and Cnesterodon.

Character 125 - Serrae on R5p: (0) absent; (1) present.

Most cyprinodontiforms lack serrae on R5p (state 0). Girardinus, Quintana, and Carlhubbsia are unique among poeciliines by the possession of serrae on R5p (state 1). This derived feature is interpreted as independent acquisitions by Girardinus and by the ancestor of Quintana and Carlhubbsia.

Character 126 - Degree of fusion between lower and upper branches of sixth anal-fin ray in adult males (R6a and R6p): (0) absent; (1) partial; (2) total.

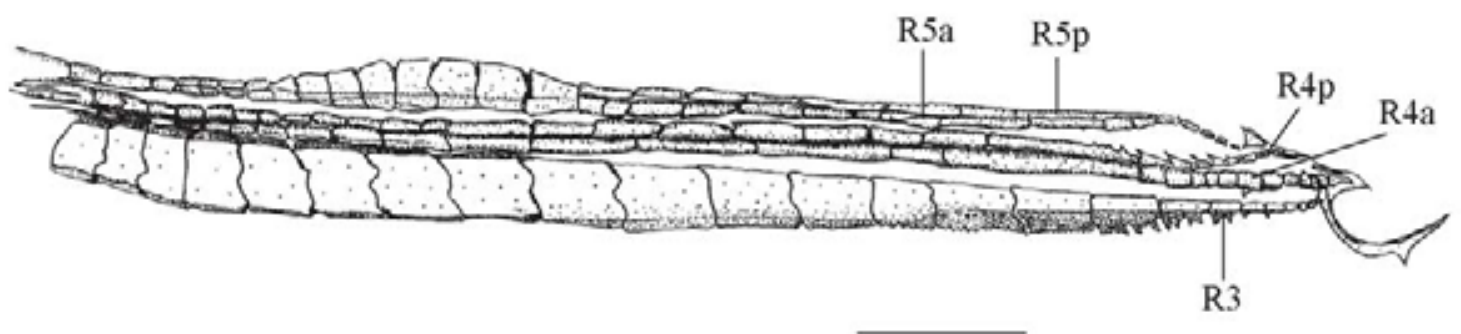

Fig. 28. Gonopodium of Cnesterodon n. sp. A, paratype, MZUSP 54978. Scale bar $1 \mathrm{~mm}$. 
In members of the outgroup, Alfaro, Brachyrhaphis, Pseudopoecilia, Pamphorichthys, Micropoecilia, and " Poecilia" R6a and R6p are free from each other (state 0). Remaining poeciliines present various degrees of partial fusion between these elements (state 1). These branches are totally fused in Poeciliopsis and Phalloptychus (state 2). Our results allow the assumption that state 1 appeared independently in Tomeurus and in the ancestor of members of the Clade 124, with two subsequent reversals: (1) in Pseudopoecilia and (2) in the node Pamphorichthys + Micropoecilia + "Poecilia" [Clade 92]. State 2 is interpreted as synapomorphic for Poeciliopsis and Phalloptychus [Clade 105].

Character 127 - Degree of fusion between more distal elements of branches of sixth anal-fin ray in adult males (R6): (0) not fused; segmented; (1) partially fused; (2) totally fused.

In members of the outgroup, Alfaro, Brachyrhaphis, Belonesox, Pseudopoecilia, Pamphorichthys, Micropoecilia, and "Poecilia" the more distal elements of R6 branches are not fused (state 0). In males of Tomeurus, Priapella, Priapichthys, Heterandria, Gambusia, Phallichthys, Quintana, Carlhubbsia, Xiphophorus, Poecilia, Limia, Phallotorynus, and some species of Phalloceros more distal elements of R6 branches are partially fused (state 1). These elements are totally fused (state 2) in remaining taxa studied. Although this character contributed to the resolution of the present topology, it presented several independent acquisitions and reversals during the history of the Cyprinodontiformes.

Character 128 - Distal portion of R6: (0) not expanded; (1) expanded.

The distal portion of R6 of most cyprinodontiform fishes is not expanded (state 0). Neoheterandria, Phallichthys, Carlhubbsia, Cnesterodon, and Phallotorynus are unique among poeciliines by the possession of an expanded distal portion of R6 (state 1; Ghedotti, 2000: fig. 14D). Following our results, this feature is interpreted as independently acquired in all genera above.

Character 129 - Size of lower branch of R6: (0) longer than upper branch; (1) as long as upper branch.

In most cyprinodontiforms the lower branch of R6 is longer than the upper branch (state 0). In Phalloptychus species the lower branch is as long as the upper (state 1), which is assumed as synapomorphic for Phalloptychus species

Character 130 - Distal portion of R6 and seventh anal-fin ray in adult males (R7): (0) not fused; (1) fused.

In most cyprinodontiforms distal portion of R6 and R7 are not free (state 0). In Phallotorynus n. sp. A and Phallotorynus n. sp. B distal portion of R6 and R7 are fused to each other (state 1). This is hypothesized as synapomorphic for a clade containing these two species.

\section{Caudal Fin}

Character 131 - Hypural plate: (0) completely fused; (1) partially fused with an elongate aperture; (2) bipartite; (3) almost bipartite, very large aperture.

Ghedotti (2000) employed this character recognizing the states 0 and 2 above. Ghedotti (2000) reported a bipartite hypural plate in Gambusia, Alfaro, Poecilia, and Phallichthys. Hypural plate is completely fused (state 0) in Fluviphylax, Cyprinodon, Fundulus, Brachyrhaphis, Priapella, Pseudopoecilia, Scolichthys, Xenodexia, Limia, Pamphorichthys hollandi, and Cnesterodon. In Procatopus, Gambusia, Girardinus, Heterandria, Carlhubbsia, Xiphophorus, Micropoecilia, Phallotorynus, and Phalloceros (except Phalloceros n. sp. G) hypural plate is partially fused with an elongate aperture (state 1). A bipartite hypural plate (state 2) is present in Belonesox, Xenophallus, Poeciliopsis, Phalloptychus, Poecilia, and Pamphorichthys scalpridens. Phalloceros n. sp. G possesses a hypural plate almost bipartite, with a very large aperture (state 3 ). Although this character contributed to the resolution of the present topology, it presented several independent acquisitions and reversals during the history of the Cyprinodontiformes.

Character 132 - Number of caudal-fin rays in contact with the hypural plate: (0) less than nine; (1) nine or more.

In Aplocheilichthys, Fluviphylax, Procatopus, Tomeurus, Brachyrhaphis, Belonesox, Gambusia, Xenophallus, Phalloptychus eigenmanni, Pamphorichthys, Micropoecilia, "Poecilia", Cnesterodon septentrionalis, Phallotorynus, and Phalloceros (except Phalloceros n. sp. G and Phalloceros n. sp. I) the number of caudal-fin rays in contact with the hypural plate is less than nine (state 0 ). In remaining taxa studied there is nine or more (state 1) caudal-fin rays in contact with the hypural plate. Although this character contributed to the resolution of the present topology, it presented several independent acquisitions and reversals during the history of the Cyprinodontiformes.

\section{Pigmentation}

Character 133 - Elongate vertical bars on lateral surface of body (Fig. 29): (0) absent; (1) present.

Poeciliopsis and Quintana are unique among poeciliines by the possession of elongate vertical bars reaching dorsal and ventral profiles plus short bars peduncle caudal. Our results support the hypothesis that this derived feature is independently acquired by Girardinus and by the ancestor of Quintana and Poeciliopsis.

Character 134 - Spot on median region of flank: (0) absent; (1) rounded; (2) elliptical; (3) squared; (4) elongate forming a bar vertical reaching dorsal and ventral profiles; (5) typically densely pigmented rectangle-like lateral spot located on the 14 th or 15th (very rarely 16th) scale of longitudinal line.

Most cyprinodontiforms lack a spot on median region of flank (state 0). Such a spot is present in some individuals of Neoheterandria (coded “-”), Scolichthys, and Phalloceros (except Phalloceros n. sp. A and Phalloceros n. sp. G). This 
spot is round (state 1, Fig. 30a) in Phalloceros n. sp. B, Phalloceros n. sp. C and Phalloceros n. sp. D, and elliptical in most species of Phalloceros (state 2, Fig. 30b). An elliptical spot appeared independently in Phalloceros and in the clade Neoheterandria + Scolichthys.

Phalloceros n. sp. P possesses an autapomorphic-squared spot (state 3, Fig. 30c). In Phalloceros n. sp. H the spot is elongate forming a bar vertical reaching dorsal and ventral profiles (state 4, Fig. 30d) and it is autapomorphic for this species. Phalloceros n. sp. F also possesses an autapomorphic spot, which is typically densely pigmented rectangle-like lateral spot more anterior located (on the $14^{\text {th }}$ or $15^{\text {th }}$, very rarely $16^{\text {th }}$, scale of longitudinal line) (state 5; Fig. 30e).

Character 135 - Number of round to elliptical dark blotch along ventral half of flank: (0) zero [absent] (Fig. 31a); (1) one (Fig. 31b); (2) two (Fig. 31c); (3) four or more (Fig. 31d).

Phallotorynus species, with the exception of $P$.fasciolatus are unique among cyprinodontiforms by the possession of round to elliptical dark blotches along ventral half of flanks. Therefore, this feature is interpreted as synapomorphic for a clade comprising Phallotorynus jucundus, Phallotorynus victoriae, Phallotorynus n. sp. A, and Phallotorynus n. sp. B. Phallotorynus jucundus exhibits four to seven blotches, and it is considered as an autapomorphy. Phallotorynus n. sp. A presents two blotches, and this state is considered autapomorphic for this species.

Character 136 - Pigmentation of dorsal fin: (0) slightly pigmented with black; (1) moderately pigmented with black; (2) densely pigmented with black.

Most cyprinodontiforms possess the dorsal fin slightly pigmented with black (state 0, Fig. 32a). In Cyprinodon, Brachyrhaphis, Poecilia, Xenophallus, Micropoecilia, and Phallotorynus dorsal fin is moderately pigmented with black (state 1, Fig. 32b), and this feature seems to be independently acquired in each of these genera. An autapomorphic dorsal fin densely pigmented with black (state 2, Fig. 32c) is present in Phallotorynus jucundus.

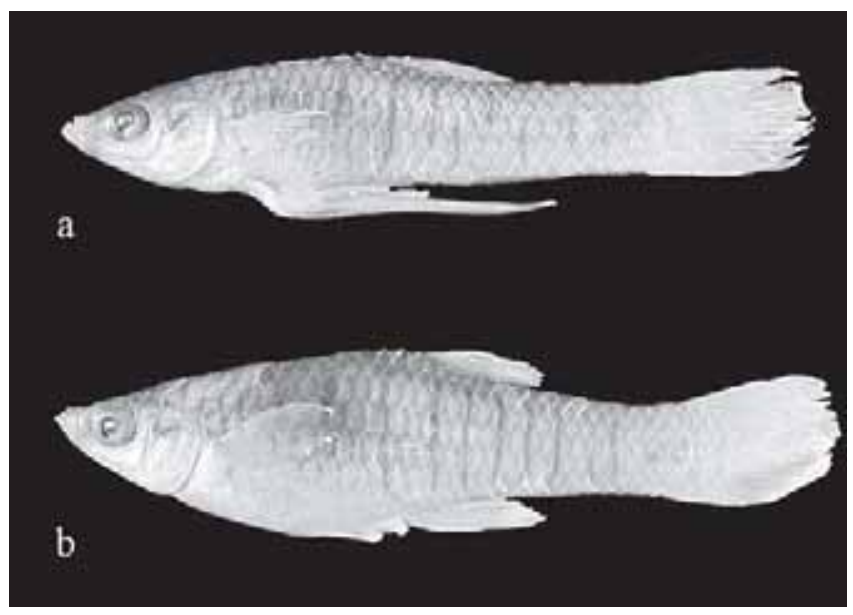

Fig. 29. Phalloptychus iheringii. (a), male, $18.35 \mathrm{~mm}$ SL. (b), female, $25.67 \mathrm{~mm} \mathrm{SL}$.

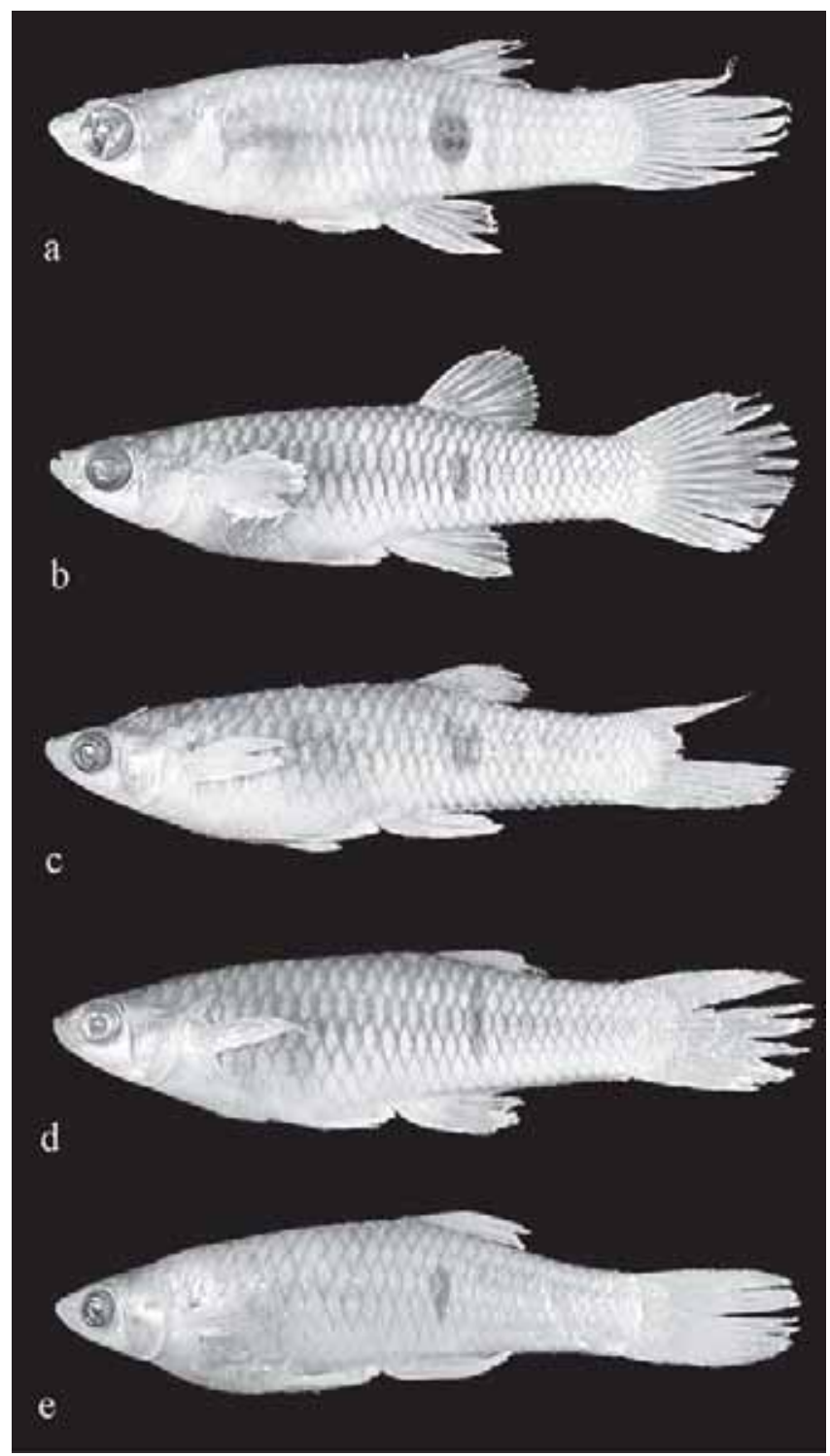

Fig. 30. (a) Phalloceros n. sp. B, female, MCP 30548, 24.4 mm SL; (b) Phalloceros n. sp. Q, female, MCP 31141, 29.9 mm SL; (c) Phalloceros n. sp. P, female, MCP 30511, 31.8 mm SL; (d) Phalloceros n. sp. H, female, MCP 12603, 41.3 mm SL; (e) Phalloceros n. sp. F, female, MNRJ 22509, 33.7 $\mathrm{mm}$ SL.

Character 137 - Dark stripe on median portion of dorsal fin (Fig. 32a): (0) absent; (1) present.

Most cyprinodontiforms lack a dark stripe on median portion of dorsal fin (state 0, Figs. 29, 34). Such a stripe is present in Brachyrhaphis, Priapichthys, Heterandria, Gambusia, Pseudopoecilia, Neoheterandria, Scolichthys, Xiphophorus, Poecilia, Limia, Pamphorichthys, Micropoecilia, "Poecilia", Phallotorynus, and Phalloceros (state 1, Fig. 32a). Our results support the hypothesis that the derived condition appeared at the ancestor of Clade 125, with subsequent reversals in Belonesox, Priapella, Xenodexia and re-acquisitions in Clades 112, 106 and Quintana. 


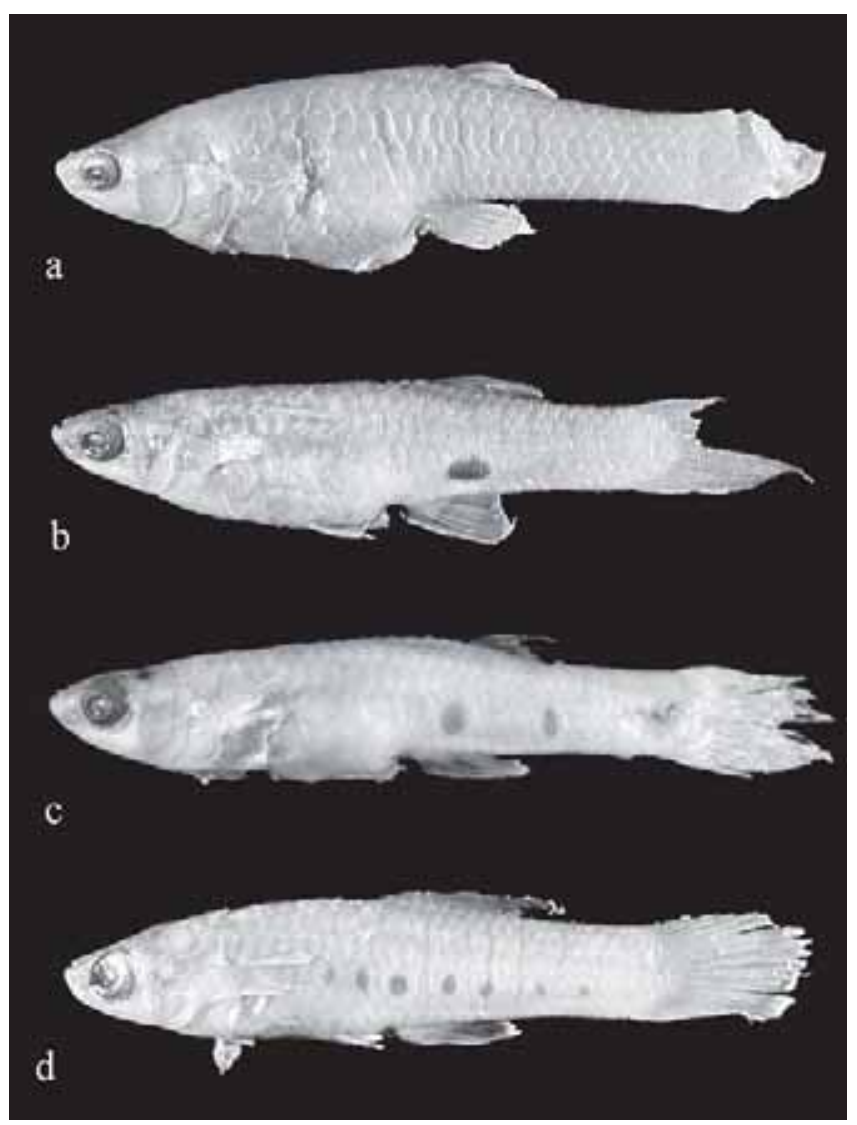

Fig. 31. (a) Phallotorynus fasciolatus. MZUSP 41373, female, $28.5 \mathrm{~mm}$ SL; (b) Phallotorynus n. sp. B. NRM 33530, female, 25.25 mm SL; (c) Phallotorynus n. sp. A, female, NRM 41848, $18.1 \mathrm{~mm}$ SL; (d) Phallotorynus jucundus, Female, MCP 25415, $21.9 \mathrm{~mm}$ SL.

Character 138 - Dark patch of pigmentation along R3: (0) absent; (1) present.

Most cyprinodontiforms lack a dark patch of pigmentation along R3 (state 0, Fig. 34). Scolichthys, Girardinus, Phallichthys, Xenophallus, Phalloptychus, Xiphophorus, Phallotorynus, and Phalloceros exhibit a dark patch of pigmentation along R3 (state 1, Fig. 33). According to the present analysis, this feature evolved independently in (1) Scolichthys, (2) Xiphophorus, (3) in the ancestor of Phallotorynus and Phalloceros; and (4) in the ancestor of Girardinus, Phallichthys, Xenophallus, Phalloptychus, and Poeciliopsis [Clade 116], with a reversal in Poeciliopsis.

Character 139 - Dark spot posterior to anal-fin base of males continuous ventrally side by side and continuous with ventral median line of caudal peduncle (Fig. 34): (0) absent; (1) present.

Rosa \& Costa (1993) suggested that the presence of a dark spot posterior to anal-fin base of males continuous ventrally side by side and continuous with ventral median line of caudal peduncle could be a synapomorphy for the species of Cnesterodon. This is confirmed by our phylogenetic study.

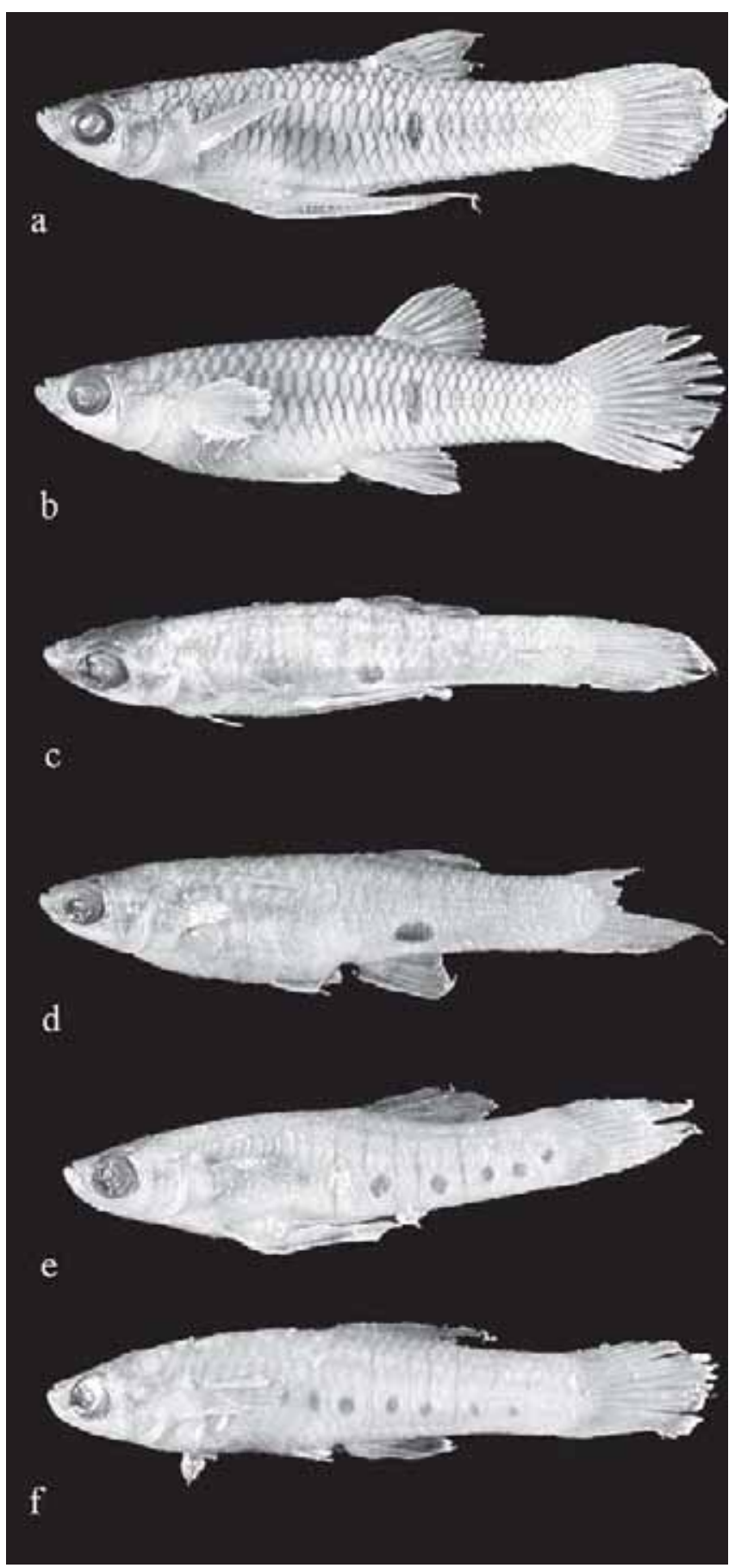

Fig. 32. (a) Phalloceros n. sp. Q, male, $26.4 \mathrm{~mm} \mathrm{SL,} \mathrm{MCP}$ 31142; (b) Female, MCP 31141, 29.9 mm SL; (c) Phallotorynus n. sp. B, male, 15.9 mm SL. MNHNP 4621; (d) Female, NRM 33530, 25.2 mm SL; (e) Phallotorynus jucundus, male, MCP 30467, 18.4 mm SL; (f) Female, MCP 25415, $21.9 \mathrm{~mm}$ SL.

Character 140 - Ground pigmentation of anal fin of females: (0) slightly speckled with black, or hyaline, not forming a distinct stripe on first rays; (1) moderately speckled with black, with chromatophores more concentrated anteriorly and forming a dark stripe on first rays; (2) black. 


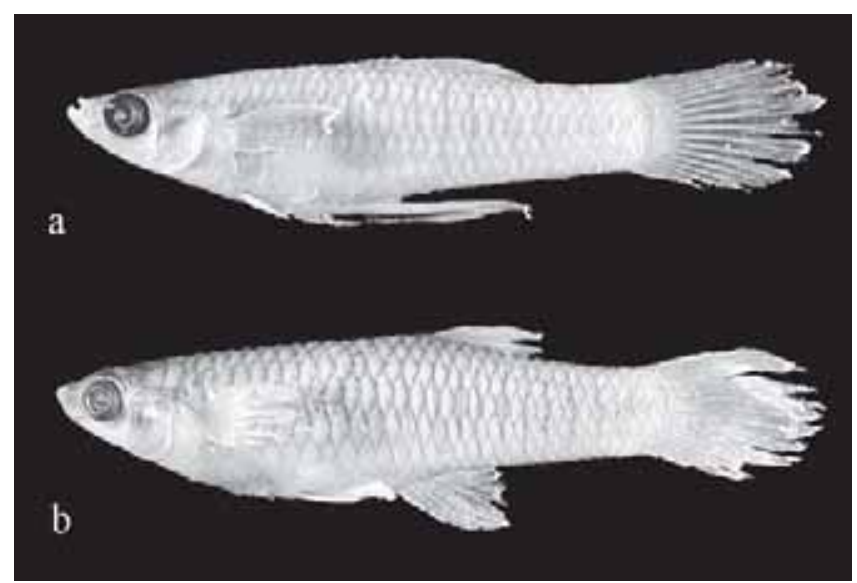

Fig. 33. Phalloceros n. sp. U. (a), male, 19.9 mm SL, MCP 30468. (b), female, MCP 30023, 31.5 mm SL.

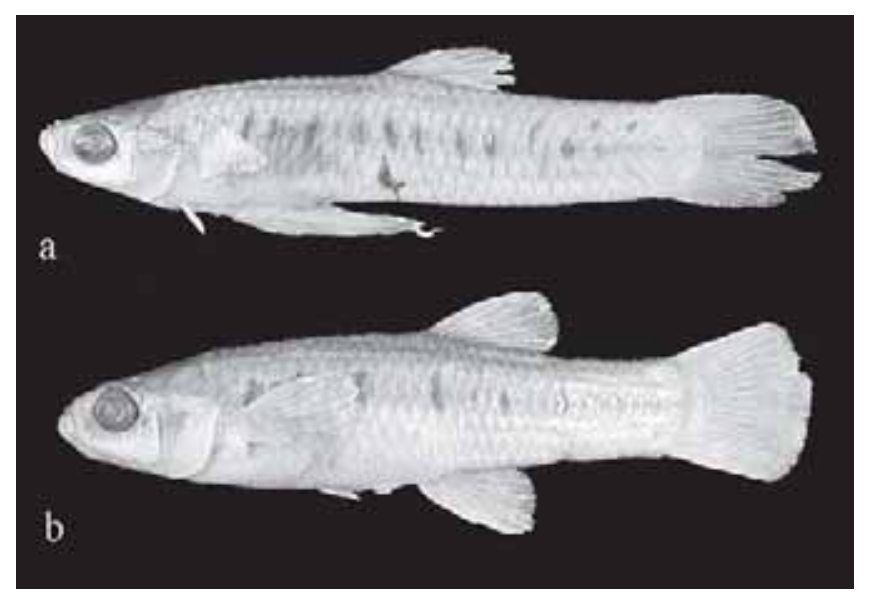

Fig. 34. Cnesterodon brevirostratus. MCP 26050. (a), male, $25.2 \mathrm{~mm}$ SL. (b), female, $33.7 \mathrm{~mm}$ SL.

Most female cyprinodontiforms possess anal fin slightly speckled with black, or hyaline, not forming a distinct stripe on first rays (state 0, Fig. 32a). Females of Phallotorynus species are unique among cyprinodontiforms by the possession of a anal fin moderately to densely speckled with black, with chromatophores more concentrated anteriorly and forming a dark stripe on first rays (states 1 and 2, Fig. $32 \mathrm{~b}, \mathrm{c})$. This condition is herein interpreted as synapomorphic for the genus and the possession of a black anal fin (state 2, Fig. 32c) is considered as a derived autapomorphy for Phallotorynus jucundus.

\section{Miscellaneous}

Character 141 - Viviparity: (0) absent; (1) present.

Viviparity among cyprinodontiform fishes has long been discussed (e.g. Rosen \& Bailey, 1963; Parenti, 1981; Meyer \& Lydeard, 1993; Ghedotti, 2000). Among cyprinodontiforms viviparity evolved independently in the Goodeidae, Anablepidae, and Poeciliinae. Tomeurus was coded "_" because it exhibits facultative viviparity. Since Tomeurus is the most basal poeciliine according to the present phylogenetic hypothesis, the facultative viviparity could be viewed in two different ways: (1) as a preliminary "testing" stage of viviparity towards "true viviparity" which was achieved by the ancestor of remaining poeciliines; or (2) as an autapomorphic specialized condition of viviparity adaptable for different environmental conditions.

Character 142 - Position of urogenital papilla of females: (0) along of median ventral line; (1) turned to the right; (2) turned to the left.

Females of most cyprinodontiforms possess the urogenital papilla on the median ventral line (state 0 ). Urogenital papilla of females is turned to the right (state 1) and is interpreted as synapomorphic for [Phalloceros n. sp. $\mathrm{N}+$ Phalloceros n. sp. $\mathrm{R}+$ Phalloceros $\mathrm{n}$. sp. $\mathrm{I}+$ Phalloceros $\mathrm{n}$. sp. $\mathrm{O}+$ Phalloceros n. sp. $\mathrm{P}+$ Phalloceros n. sp. $\mathrm{M}+$ Phalloceros $\mathrm{n} . \mathrm{sp} . \mathrm{H}+$ Phalloceros $\mathrm{n}$. sp. $\mathrm{Q}+$ Phalloceros $\mathrm{n}$. sp. J + Phalloceros n. sp. L] [Clade 76]. Urogenital papilla of females is turned to the left (state 2) and is interpreted as synapomorphic for [Phalloceros n. sp. E + Phalloceros n. sp. $\mathrm{G}+$ Phalloceros n. sp. F] [Clade 81].

Character 143 - Orbital bones: (0) absent; (1) anterior and posterior; (2) anterior only.

In Fluviphylax, Fundulus, Jenynsia, Brachyrhaphis, Tomeurus, Phalloptychus, Xenodexia, and Cnesterodon (except Cnesterodon n. sp. A) orbital osseous plates are absent (state 0). Pseudopoecilia and Quintana exhibit one anterior orbital bones (state 2). Remaining taxa studied possess two orbital osseous plates (anterior and posterior ones) (state 1). Although this character contributed to the resolution of the present topology, it presented several independent acquisitions and reversals during the history of the Cyprinodontiformes.

\section{Phylogenetic reconstruction and synapomorphy list}

The phylogenetic analysis yielded 96 equally most parsimonious trees with length $(\mathrm{L})=758$ steps (including TSA in the outgroup), consistency index $(\mathrm{CI})=0.35$, and retention index $(\mathrm{RI})=0.75$. A strict consensus tree is shown in Figs. 1, 2, and 3. Synapomorphy list is presented in the "Taxonomic Account" section and in the Appendix III. Fits of individual characters are summarized in Appendix IV.

\section{Taxonomic Account}

The current phylogenetic study supports the proposal of a new classification for the subfamily Poeciliinae. These modifications are necessary in order to make groups natural (monophyletic). Diagnoses are provided for suprageneric clades. Nevertheless, diagnoses for monotypic tribes are only preliminary because this study focused on the search for derived features uniting genera rather than on generic autapomorphies. Thus, generic diagnoses were not fully surveyed during this study. Oncoming studies will possibly reveal several other diagnostic features for these monotypic tribes. Some authors (e.g. Regan, 1913; Hubbs, 1924; Rosen, 
1952; Rosen, 1979; Rosen \& Bailey, 1963; Rauchenberger, 1989; Rodriguez, 1997) already provided some insight on diagnostic characters for some of these tribes but not necessarily on the light of a phylogenetic framework. Rather than writing down the diagnoses and discussions of these monotypic clades, we refer the reader to the articles above for a detailed study.

Thus, the following classification is proposed (summarized in Table 3):

Table 3. Proposed Classification of Poeciliinae

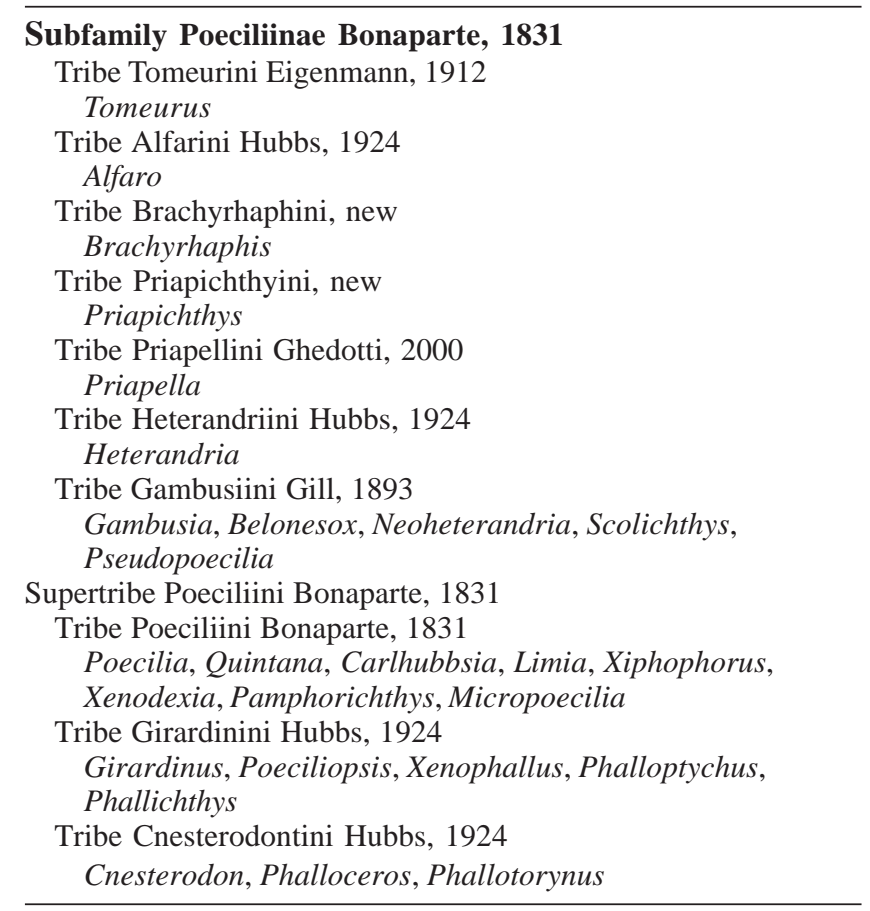

\section{Subfamily Poeciliinae Bonaparte}

[Clade 129]

Poecilini Bonaparte, 1831: 94, unavailable name; preoccupied in Coleoptera.

Poeciliini Bonaparte, 1831. Type-genus: Poecilia Bloch \& Schneider, 1801.

Diagnosis. Poeciliines species share the following uniquely derived and unreversed features: (1) ventral portion of proximal anal-fin radials 6 to 10 in adult males not laterally compressed without anterior and posterior flanges [82-1**] (a condition found in other members of the Superfamily Poeciloidea, except for Fluviphylax); and (2) anal-fin rays 3, 4 , and 5 in adult males modified in copulatory structure [86$1 * *]$.

Additionally, poeciliines can be diagnosed by the following not uniquely derived and/or reversed features: (1) six branchiostegal rays [22-1]; (2) anterior process of anterior ceratohyal not extending ventral to ventral hypohyal [24-1*]; (3) females with 10 anal-fin rays [65-1]; (4) second, third, and fourth gonactinosts into a gonactinost complex [67-1*]; (5) complete fusion of second and third gonactinosts [72-1]; fusion of anal-fin posterior median radials ( $5^{\text {th }}$ to last one) in adult males to respective proximal radials [77-1]; (6) twelve anal-fin rays of males [85-1*]; (7) squared and antrorse spines on subdistal segments of R3 [108-1]; (8) nine or more caudal-fin rays in contact with the hypural plate [132-1]; (9) anterior and posterior orbital bones (143-1); and (10) viviparity [141-1*].

Composition. Tribes Tomeurini, Alfarini, Brachyrhaphini, Priapichthyini, Priapellini, Heterandriini, Gambusiini, Poeciliini, and Cnesterodontini.

Distribution. North America through Central America, the Caribbean, through South America to Argentina.

Remarks. The family name Poecilini has already been used by Bonaparte (1831), however it appeared to be preoccupied in Coleoptera. The family-group name based on Poecilus Bonelli (Carabidae) was created by Bonelli in 1810 . He called the group "Poecilii", which is typically taken to be a familygroup name. When it is used these days, it is either as a tribe (Poecilini) or a subtribe (Poecilina) (David Maddison, in litt.). Later, Bonaparte (1846) added one " $i$ " to the name differing it from the Coleoptera family-group name (even if the differences between two family-group names is only one letter they are not homonyms - article 55.4 of the ICZN, 1999).

However, Poeciliini Bonaparte, 1846 is an unjustified emendation for Poecilini Bonaparte, 1831 (article 32.5.3 of the ICZN, 1999) but it is in prevailing usage. So, it is attributed to the original author and date and is deemed to be a justified emendation following the article 33.2.3.1 of the ICZN (1999).

\section{Tribe Tomeurini Eigenmann} [Clade 63]

Tomeurini Eigenmann, 1912: 460. Type-genus: Tomeurus Eigenmann, 1909.

Diagnosis. Tomeurins can be diagnosed by the following uniquely derived features: (1) preopercular canal partially closed, only canals between pores 11-12, and 12-U closed (sometimes canal U-V also closed) [8-4*]; (2) three pelvicfin rays in females [44-2*]; (3) haemal arch and spine of vertebrae 13-17 in adult males absent [47-1*]; (4) first proximal radial of dorsal fin in adult males located between neural spines of $23^{\text {rd }}$ and $24^{\text {th }}$ or $24^{\text {th }}$ and $25^{\text {th }}$ vertebrae [62-3*]; (5) adult females with first proximal radial of dorsal fin located between neural arches of vertebrae $6 ; 23$ and 24 or 24 and 25 [63-6*]; and (6) six dorsal-fin rays (males and females) [64-4*].

Additionally, tomeurins can be diagnosed by the following not uniquely derived and/or reversed features: (1) anterior margin of frontals extend anterior by between nasals [10]; (2) parietals short restricted to the epiotic region, not reaching sphenotic anteriorly [2-1]; (3) absence of an epiotic pro- 
cess [3-3]; (4) posterior section of posterior remnant of infraorbital system opened into a groove [7-1]; (5) preorbital canal absent or opened, forming a very shallow groove [9-2]; (6) mandibular canal absent or opened, forming a very shallow groove [10-1]; (7) anterior process of anterior ceratohyal extending ventral to ventral hypohyal present [24-0]; (8) interarcual cartilage absent [25-1]; (9) three pelvic-fin rays in males [33-3]; (10) pelvic girdle of males located below pectoral girdle, posterior border of basipterygium anterior to posterior border of cleithrum [35-3]; (11) dorsolateral process of pelvic fin in adult males large [36-1]; (12) anterior tip of basipterygium in adult males clearly pointed [37-1]; (13) width of first pelvic-fin ray in adult males decreasing abruptly at distal portion, distal slender portion short [41-2]; (14) second pelvic-fin ray in adult males unbranched [42-1]; (15) distal portion of third and fourth gonactinosts separate, except by tip of gonactinost [74-2]; (16) eight anal-fin rays in males [85-3]; (17) dorsal expansion of ray $5 p$ of anal fin in adult males present [124-1]; (18) R6a and R6p partially fused [126-1]; (19) more distal elements of R6 branches partially fused [127-1]; and (20) orbital bones absent [143-0].

\section{Composition. Genus Tomeurus.}

\section{Distribution. As for Tomeurus.}

\section{Genus Tomeurus Eigenmann}

Tomeurus Eigenmann, 1909: 53. Genus masculine. Type-species: Tomeurus gracilis Eigenmann, 1909. Type by monotypy and original designation.

Composition. Tomeurus gracilis Eigenmann.

Distribution. Tomeurus gracilis occurs in small coastal drainages of the Venezuelan departments Delta Amacuro, Monagas, Territorio Federal, and in Brazilian states of Amapá, and Pará. The species also inhabits the drainages of rio Guamá and rio Tocantins in Brazil, the drainages of the Cuyuni, Mazaruni, and Essequibo Rivers in the Guyana and Courantyne rivier drainage in Suriname.

\section{Tribe Alfarini + Tribe Brachyrhaphini + Tribe Priapichthyini + Tribe Priapellini + Tribe Heterandriini + Tribe Gambusiini + Supertribe Poeciliini \\ [Clade 126]}

Diagnosis. Members of this clade can be diagnosed by the following not uniquely derived and/or reversed features: (1) posterior supraorbital canal (2b, 3, 4a) opened, forming a sinuous depression over the frontal (supraorbital bone) [5-1*]; (2) anterior section of posterior remnant of infraorbital system (canal 4b, 5, 6a) opened, pores confluent forming a major sinuous depression above and slightly behind the orbit [61]; (3) medial surface of ascending process of premaxilla slightly angled laterally [11-1*]; (4) anterior border of ventral maxilla concave [14-1]; (5) pelvic girdle of males posteriorly located; posterior border of cleithrum approximately aligned with center of basipterygium (or more posterior) [35-1]; (6) ligastyle with one axis [46-1]; and (7) adult males with anterior process on base of fifth middle anal-fin radial pointed and upward directed [78-1].

\section{Tribe Alfarini Hubbs \\ [Clade 64]}

Alfarini Hubbs, 1924: 11.Type-genus: Alfaro Meek, 1912.

Diagnosis. Alfarins can be diagnosed by the following not uniquely derived and/or reversed features: (1) pleural ribs associated with haemal arches in males [60-1]; (2) pleural ribs associated with haemal arches in females [61-1]; (3) adult females with first proximal radial of dorsal fin located between neural arches of $14^{\text {th }}$ and $15^{\text {th }}$ vertebrae; (4) 12 or more anal-fin rays in females [65-0]; (5) gonactinost complex approximately perpendicular to body longitudinal axis [68-1]; (6) distal portion of second and third gonactinosts fused [71-1]; (7) distal portion of third and fourth gonactinosts completely fused [74-1]; (8) lateral process on base of fifth middle anal-fin radial in adult males minute [79-4]; and (9) presence of a palp in subdistal segments of R3 [88-1].

Composition. Genus Alfaro.

Distribution. As for Alfaro.

\section{Alfaro Meek}

Petalosoma Regan, 1908: 458. Type species: Petalosoma cultratum Regan, 1908. Type by monotypy. Gender: neuter. Preoccupied by Petalosoma Lewis, 1903 in Coleoptera. Alfaro Meek, 1912: 72. Type species: Alfaro acutiventralis Meek, 1912. Type by monotypy. Gender: masculine.

Petalurichthys Regan, 1912: 494 [footnote]. Type species: Petalosoma cultratum Regan, 1908. Type by being a replacement name. Gender: masculine.

Furcipenis Hubbs, 1931: 1. Type species: Priapichthys huberi Fowler, 1923. Type by original designation. Gender: masculine.

Composition. Alfaro cultratus (Regan) and A. huberi (Fowler)

Distribution. Southern Guatemala, Honduras, Costa Rica, Nicaragua, and Western Panama.

\section{Tribe Brachyrhaphini + Tribe Priapichthyini + Tribe Priapellini + Tribe Heterandriini + Tribe Gambusiini + Supertribe Poeciliini} [Clade 125]

Diagnosis. Members of this clade share the following uniquely derived and unreversed features: (1) haemal arch and spine 
of vertebrae 13-17 in adult males modified into gonapophyses [47-2**]; and (2) lateral process on base of fifth middle analfin radial in adult males large [79-1**].

Additionally, they can be diagnosed by the following not uniquely derived and/or reversed features: (1) epiotic process longer than exoccipital process but not reaching first pleural rib [31 *]; (2) preorbital canal partially closed bearing two upper pores and a lower deep groove [9-1]; (3) three well-developed gonapophyses [48-1*]; (4) functional gonapophyses located on vertebrae 14, 15, and 16 [49-1*]; (5) gonactinost complex inclined forward, forming an angle wider than $90^{\circ}$ relative to the body longitudinal axis [68-2*]; (6) basal process on first gonactinost small [69-1*]; (7) second and third gonactinosts partially fused [72-2*]; (8) anal-fin posterior median radials ( $5^{\text {th }}$ to last one) in adult males not fused to respective proximal radials [77-0]; (9) one series of subdistal retrorse spines on R4p [114-1*]; (10) eight or more subdistal retrorse spines on R4p [116-1]; and (11) dark stripe present on median portion of dorsal fin [137-1].

\section{Tribe Brachyrhaphini, new [Clade 61]}

Type-genus: Brachyrhaphis Regan, 1913.

Diagnosis. Brachyrhaphins can be diagnosed by the following not uniquely derived and/or reversed features: (1) anterior margin of frontals extend anterior by between nasals [1-0]; (2) anterior process of anterior ceratohyal extending ventral to ventral hypohyal present [24-0]; (3) pelvic girdle of males very posterior, anterior border of basipterygium posterior to the posterior border of cleithrum [35-0]; (4) second gonapophysis approximately perpendicular to vertebral column [54-4]; (5) first proximal radial of dorsal fin in adult males located between neural spines of $11^{\text {th }}$ and $12^{\text {th }}$ vertebrae [62-6]; (6) adult females with first proximal radial of dorsal fin located between neural arches of $11^{\text {th }}$ and $12^{\text {th }}$ vertebrae [63-3]; (7) nine dorsal-fin rays (males and females) [641]; (8) anterior process on base of fifth middle anal-fin radial in adult males hardly developed and round [78-2]; (9) ninth gonactinost bearing wing-like lateral projections [84-1]; (10) males with 10 anal-fin rays [85-0]; (11) R5a, R5p, R4a, and R4p directed upwards [112-1]; (12) less than nine caudal-fin rays in contact with the hypural plate [132-0]; (13) dorsal fin moderately pigmented with black [136-1]; (14) ground pigmentation of anal fin of females moderately speckled with black, with chromatophores more concentrated anteriorly and forming a dark stripe on first rays [140-1]; and (14) orbital bones absent [143-0].

Composition. Genus Brachyrhaphis.

Distribution. As for Brachyrhaphis.

\section{Brachyrhaphis Regan}

Brachyrhaphis Regan, 1913: 997. Type species: Gambusia rhabdophora Regan, 1908. Type by monotypy. Gender: feminine.
Trigonophallus Hubbs, 1926: 48. Type species: Trigonophallus punctifer Hubbs, 1926. Type by original designation. Gender: masculine.

Plectrophallus Fowler, 1932: 384. Proposed as new subgenus of Panamichthys Hubbs. Type species: Panamichthys tristani Fowler, 1932. Type by original designation. Gender: masculine.

Composition. Brachyrhaphis cascajalensis (Meek \& Hildebrand), B. episcopi (Steindachner), B. hartwegi Rosen \& Bailey, B. hessfeldi Meyer \& Etzel, B. holdridgei Bussing, B. parismina (Meek), B. punctifer (Hubbs), B. rhabdophora (Regan), B. roseni Bussing, B. roswithae Meyer \& Etzel, B. terrabensis (Regan).

Distribution. Mexico (southern Pacific drainages), Costa Rica (Pacific and Atlantic drainages), Guatemala, Panama (central and western).

\section{Tribe Priapichthyini + Tribe Priapellini + Tribe Heterandriini + Tribe Gambusiini + Supertribe Poeciliini}

[Clade 124]

Diagnosis. Members of this clade can be diagnosed by the following not uniquely derived and/or reversed features: (1) anterior tip of basipterygium in adult males clearly pointed [37-1]; (2) third gonapophysis forming an angle of 35-70 degrees relative to vertebral column [55-1]; (3) absence of an anterior convex expansion of second gonactinost [70-1]; (4) males with eleven anal-fin rays [85-2]; (5) R6a and R6p partially fused [126-1]; and (6) more distal elements of R6 branches partially fused [127-1].

\section{Tribe Priapichthyini, new [Clade 55]}

Type-genus: Priapichthys Regan, 1913

Diagnosis. Priapichthyins share the following uniquely derived and unreversed features: (1) mandibular canal present and partially closed bearing six pores [10-3*]. Additionally, this tribe can be diagnosed by the following not uniquely derived and/or reversed features: (1) ascending process of premaxilla elongate, distal tip pointed [12-1]; (2) second gonapophysis forming an angle of 45-70 degrees relative to vertebral column [54-1]; (3) absence of a basal process on first gonactinost [69-0]; (4) distal portion of second and third gonactinosts fused [71-1]; (5) complete fusion of second and third gonactinosts [72-1]; (6) distal portion of third and fourth gonactinosts completely fused [74-1]; (7) eighth gonactinost bearing wing-like lateral projections [83-1]; and (8) ninth gonactinost bearing wing-like lateral projections [84-1].

Composition. Genus Priapichthys. 
Distribution. As for Priapichthys.

\section{Priapichthys Regan}

Priapichthys Regan, 1913: 991. Type species: Gambusia annectens Regan, 1907. Gender: masculine.

Diphyacantha Henn, 1916: 113. Type species: Diphyacantha chocoensis Henn, 1916. Type by monotypy. Gender: feminine.

Darienichthys Hubbs, 1924: 8 [footnote]. Type species: Gambusia darienensis Meek \& Hildebrand, 1913. Type by original designation. Gender: masculine.

Panamichthys Hubbs, 1924: 8 [footnote]. Type species: Priapichthys panamensis Meek \& Hildebrand, 1916. Type by original designation. Gender: masculine.

Alloheterandria Hubbs, 1924: 9 [footnote]. Type species: Gambusia nigroventralis Eigenmann \& Henn, 1912. Type by original designation. Gender: feminine.

Composition. Priapichthys annectens (Regan), P. caliensis (Eigenmann \& Henn), P. chocoensis Henn, $P$. darienensis (Meek \& Hildebrand), P. nigroventralis (Eigenmann \& Henn), $P$. panamensis Meek \& Hildebrand, P. puetzi Meyer \& Etzel.

Distribution. Costa Rica (Pacific and Atlantic drainages), Panama (Pacific drainages), Ecuador and Colombia.

\section{Tribe Priapellini + Tribe Heterandriini + Tribe Gambusiini + Supertribe Poeciliini [Clade 123]}

Diagnosis. Members of this clade can be diagnosed by the following not uniquely derived and/or reversed features: (1) ligastyle triangular [46-2]; (2) curvature of gonapophysis forming an angle of 16-45 degrees relative to vertebral column [53-1*]; (3) pleural ribs 7, 8, and 9 in adult males curved forward converging to the same point towards pelvic girdle [59-1*]; (4) females with eleven analfin rays [65-2]; and (5) elongate and dorsal protuberance present along $\mathrm{R} 4 \mathrm{p}$ (just behind retrorse spines series) of anal fin in adult males [118-1].

\section{Tribe Priapellini Ghedotti [Clade 62]}

Priapellini Ghedotti, 2000: 39. Type genus: Priapella Regan, 1913

Diagnosis. Priapellins share the following uniquely derived and unreversed features: (1) mesethmoid: cartilaginous [0$\left.1^{*}\right]$; and (2) mandibular canal present and entirely closed, bearing five pores [10-2*].

Additionally, priapellins can be diagnosed by the following not uniquely derived and/or reversed features: (1) anterior margin of frontals straight or slightly cleft medially [1-1]; (2) absence of an epiotic process [3-3]; (3) preorbital canal present and entirely closed, bearing four pores [9-0]; (4) anterior border of ventral maxilla straight [14-0]; (5) interarcual cartilage absent [25-1]; (6) pleural ribs associated with haemal arches in males [60-1]; (7) pleural ribs associated with haemal arches in females [61-1]; (8) absence of an anterior convex expansion of second gonactinost [70-0]; and (9) absence of a dark stripe on median portion of dorsal fin [137-0].

Composition. Genus Priapella.

Distribution. As for Priapella.

\section{Priapella Regan}

Priapella Regan, 1913: 992. Type species: Gambusia bonita Meek, 1904. Type by monotypy. Gender: feminine.

Composition. Priapella bonita (Meek), P. compressa Alvarez, $P$. intermedia Alvarez \& Carranza, P. olmecae Meyer \& Perez.

Distribution. Southern Mexico.

\section{Tribe Heterandriini + Tribe Gambusiini + Supertribe Poeciliini \\ [Clade 122]}

Diagnosis. Members of this clade can be diagnosed by the following not uniquely derived and/or reversed features: (1) anterior margin of frontals extend anterior by between nasals [1-0]; (2) posterior supraorbital canal $(2 \mathrm{~b}, 3,4 \mathrm{a})$ absent or opened, forming a shallow groove [5-0]; (3) third gonapophysis forming an angle of 10-32 degrees relative to vertebral column [55-2*]; (4) first proximal radial of dorsal fin in adult males located between neural spines of $13^{\text {th }}$ and $14^{\text {th }}$ vertebrae [62-1]; and (5) hypural plate partially fused with an elongate aperture [131-1].

\section{Tribe Heterandriini Hubbs, new usage [Clade 54]}

Heterandriini Hubbs, 1924: 7. Type-genus: Heterandria Agassiz, 1853.

Diagnosis. Heterandriins share the following uniquely derived and unreversed feature: (1) distal portion of third and fourth gonactinosts completely fused, except by a small notch [74-3*]. Heterandriins can also be diagnosed by the following not uniquely derived and/or reversed features: (1) epiotic process shorter than exoccipital process [3-2]; (2) anterior process of anterior ceratohyal extending ventral to ventral hypohyal present [24-0]; (3) dorsolateral process of pelvic fin in adult males large [36-1]; (4) width of first pelvic-fin ray in adult males decreasing abruptly at distal portion, distal slender portion long [41-1]; (5) first proximal radial of dorsal fin in adult males located between neural spines of $11^{\text {th }}$ and $12^{\text {th }}$ vertebrae [62-6]; (6) absence of a basal 
process on first gonactinost [69-0]; (7) distal portion of second and third anal-fin gonactinosts fused [71-1]; (8) membranous tip anterior to R4 and R5 curved downwards [1101]; (9) membranous tip anterior to R4 and R5 small [111-1]; and (10) dorsal expansion of ray $5 p$ of anal fin in adult males present [124-1].

Composition. Genus Heterandria.

Distribution. As for Heterandria.

\section{Heterandria Agassiz}

Heterandria Agassiz, 1853: 135. Type species: Heterandria formosa Girard, 1859. Gender: feminine. Type by subsequent designation by Bailey (1952).

Pseudoxiphophorus Bleeker, 1860: 440. Type species: Xiphophorus bimaculatus Heckel, 1848. Gender: masculine.

Poeciliodes Steindachner, 1863: 176 [15]. Type species: Poeciliodes bimaculatus Steindachner, 1863. Type by monotypy. Gender: masculine.

Composition. Heterandria anzuetoi Rosen \& Bailey, $H$. attenuata Rosen \& Bailey, H. bimaculata (Heckel), H. cataractae Rosen, $H$. dirempta Rosen, $H$. formosa Girard, $H$. jonesii (Günther), H. litoperas Rosen \& Bailey, and H. obliqua Rosen.

Distribution. Southern USA to Nicaragua (Atlantic and Gulf drainages) and Guatemala (Pacific drainage).

\section{Tribe Gambusiini + Supertribe Poeciliini [Clade 121]}

Diagnosis. Members of this clade can be diagnosed by the following not uniquely derived and/or reversed features: (1) anterior section of posterior remnant of infraorbital system absent or opened, forming a shallow groove [6-0]; (2) mandibular canal absent or opened, forming a very shallow groove [10-1]; (3) medial surface of ascending process of premaxilla angled laterally at proximal end, forming a triangle space between proximal ends of ascending processes [11-2]; (4) anterior border of ventral maxilla straight [14-0]; (5) ascending process of parasphenoids in adults short, not reaching pterosphenoids [201]; (6) adult females with first proximal radial of dorsal fin located between neural arches of $13^{\text {th }}$ and $14^{\text {th }}$ vertebrae [63-1]; and (7) nine dorsal-fin rays (males and females) [64-1].

\section{Tribe Gambusiini Gill, new usage}

[Clade 120]

Gambusiini Gill, 1893: 133. Type-genus: Gambusia Poey, 1854.

Diagnosis. Gambusiins can be diagnosed by the following not uniquely derived and/or reversed features: (1) preorbital canal absent or opened, forming a very shallow groove [9-2]; (2) ascending process of premaxilla elongate, distal tip pointed [12-1]; (3) absence of an elongate and dorsal protuberance along R4p (just behind retrorse spines series) of anal fin in adult males [118-0]; and (4) more distal elements of R6 branches not fused [127-0].

Composition. Genera Gambusia, Belonesox, Pseudopoecilia, Neoheterandria, Scolichthys.

Distribution. Northern USA to Peru (Inland, Gulf, Atlantic and Pacific drainages) including the Caribbean Islands.

\section{Gambusia + Belonesox \\ [Clade 118]}

Diagnosis. Gambusia and Belonesox share the following uniquely derived and unreversed features: (1) gonactinost 2, 3 , and 4 fused into a column [73-1**]; and (2) lateral flanges on ventral portion of anal-fin radial 4 in adult males present and continuous, without dorsal cleft [75-1**].

Additionally, this clade can be diagnosed by the following not uniquely derived and/or reversed features: (1) posterior section of posterior remnant of infraorbital system opened into a groove [7-1]; (2) pelvic girdle of males very posterior, anterior border of basipterygium posterior to the posterior border of cleithrum [35-0]; (3) anterior tip of basipterygium in adult males approximately triangular and round [37-0]; (4) pleural ribs in adult males almost straight, slightly curving forward and not converging to the same point towards pelvic girdle [59-0]; (5) pleural ribs associated with haemal arches in males [60-1]; (6) absence of an anterior convex expansion of second gonactinost [70-0]; (7) complete fusion of second and third gonactinosts [72-1]; (8) distal portion of third and fourth gonactinosts completely fused [74-1]; (9) lateral process on base of fifth middle anal-fin radial in adult males minute [79-4]; (10) R5a, R5p, R4a, and R4p directed upwards [112-1]; (11) four to seven subdistal retrorse spines on R4p [116-2]; (12) hook on 5a contacting the segments of 4p [123-1]; and (13) less than nine caudal-fin rays in contact with the hypural plate [132-0].

\section{Gambusia Poey}

Gambusia Poey, 1854: 382. Type species: Gambusia punctata Poey, 1854. Type by subsequent designation. Gender: feminine.

Paragambusia Meek, 1904: 133. Type species: Gambusia nicaraguensis Günther, 1866. Type by original designation. Gender: feminine.

Heterophallus Regan, 1914: 65. Type species: Heterophallus rachovii Regan, 1914 . Type by monotypy. Gender: masculine.

Arthrophallus Hubbs, 1926: 38. Proposed as subgenus of Gambusia. Type species: Heterandria patruelis Baird \& Girard, 1853. Type by original designation. Gender: masculine. 
Heterophallina Hubbs, 1926: 26. Proposed as subgenus of Gambusia. Type species: Gambusia regani Hubbs, 1926. Type by original designation. Gender: feminine.

Schizophallus Hubbs, 1926: 40. Proposed as subgenus of Gambusia. Type species: Gambusia holbrookii Girard, 1859. Type by original designation. Gender: masculine.

Dicerophallus Alvarez, 1952: 95. Type species: Dicerophallus echeagarayi Alvarez, 1952. Type by original designation. Gender: masculine.

Flexipenis Hubbs in Rivas, 1963: 334. Type species: Gambusia vittata Hubbs, 1926. Type by original designation. Gender: masculine.

Orthophallus Rivas, 1963: 339. Type species: Gambusia lemaitrei Fowler, 1950. Type by original designation. Gender: masculine.

Composition. Gambusia affinis (Baird \& Girard); G. alvarezi Hubbs \& Springer, G. amistadensis Peden, G. atrora Rosen \& Bailey, G. aurata Miller \& Minckley, G. beebei Myers, G. bucheri Rivas, G. clarkhubbsi Garrett \& Edwards, G. dominicensis Regan, G. echeagarayi (Alvarez), G. eurystoma Miller, G. gaigei Hubbs, G. geiseri Hubbs \& Hubbs, G. georgei Hubbs \& Peden, G. heterochir Hubbs, G. hispaniolae Fink, G. hurtadoi Hubbs \& Springer, G. krumholzi Minckley, G. lemaitrei Fowler, G. longispinis Minckley, G. luma Rosen \& Bailey, G. marshi Minckley \& Craddock, G. melapleura (Gosse); G. myersi Ahl, G. nicaraguensis Günther, G. nobilis (Baird \& Girard), G. panuco Hubbs, G. pseudopunctata Rivas, G. punctata Poey, G. manni Hubbs, G. monticola Rivas, G. puncticulata Poey, G. rachowi (Regan), G. regani Hubbs, G. rhizophorae Rivas, G. senilis Girard, G. sexradiata Hubbs, G. speciosa Girard, G. vittata Hubbs, G. wrayi Regan, G. xanthosoma Greenfield, and G. yucatana Regan.

Distribution. Northern USA to Colombia (Inland, Gulf and Pacific drainages) including the Caribbean Islands.

\section{Belonesox Kner}

Belonesox Kner, 1860: 419, 422. Type species: Belonesox belizanus Kner, 1860. Type by monotypy. Gender: masculine.

Composition. Belonesox belizanus Kner.

Distribution. Central America: from laguna San Julian, northeast of Ciudad Veracruz in Mexico to Costa Rica. Southern Gulf of Mexico, southern Yucatán and along Central American coast south to Nicaragua. Introduced in freshwater in Florida.

\section{Pseudopoecilia + Neoheterandria + Scolichthys [Clade 117]}

Diagnosis. Pseudopoecilia + Neoheterandria + Scolichthys share the following not uniquely derived and/or reversed features: (1) medial surface of ascending process of premaxilla approximately straight [11-0]; (2) ligastyle absent [46-0]; (3) 10 or more dorsal-fin rays (males and females) [64-0]; (4) males with nine anal-fin rays [85-4]; (5) spines on subdistal segments of R3 retrorse [108-2]; (6) dorsal expansion of ray 5p of anal fin in adult males present [124-1]; and (7) hypural plate completely fused [131-0].

\section{Pseudopoecilia Regan}

Pseudopoecilia Regan, 1913: 995. Type species: Poecilia festae Boulenger, 1898. Type by monotypy. Gender: feminine.

Composition. Pseudopoecilia austrocolumbiana Radda, $P$. festae (Boulenger), P.fria (Eigenmann \& Henn)

Distribution. Pacific drainages of Ecuador, Peru, and Colombia.

\section{Neoheterandria + Scolichthys \\ [Clade 114]}

Diagnosis. Neoheterandria and Scolichthys share the following uniquely derived and unreversed feature: (1) first and second branchiostegal rays united at the base [23-1**]. Additionally, Neoheterandria plus Scolichthys can be diagnosed by the following not uniquely derived and/or reversed features: (1) females with 10 anal-fin rays [65-1]; (2) ventral projection of R4a towards R3 [113-1]; and (3) more distal elements of R6 branches totally fused [127-2].

\section{Neoheterandria Henn}

Neoheterandria Henn, 1916: 117. Type species: Neoheterandria elegans Henn, 1916. Type by monotypy. Gender: feminine.

Allogambusia Hubbs, 1924: 8. Type species: Gambusia tridentiger Garman, 1895. Type by original designation. Gender: feminine.

Composition. Neoheterandria cana (Meek \& Hildebrand), $N$. elegans Henn, N. tridentiger (Garman).

Distribution. Nicaragua (Atlantic drainages), Costa Rica (Atlantic drainages), Panama (central, Atlantic and Pacific drainages), and Colombia (Atlantic drainages).

\section{Scolichthys Rosen}

Scolichthys Rosen, 1967: 2. Type species: Scolichthys greenwayi Rosen, 1967. Type by original designation. Gender: masculine.

Composition. Scolichthys greenwayi Rosen and S. iota Rosen.

Distribution. Río Chixoy, río Chajmaic, and río Salinas system in Alta Verapaz, Guatemala. 


\section{Supertribe: Poeciliini Bonaparte, new}

[Clade 119]

Poecilini Bonaparte, 1831: 94, unavailable name; preoccupied in Coleoptera.

Poeciliini Bonaparte, 1831. Type-genus: Poecilia Bloch \& Schneider, 1801.

Diagnosis. Members of the supertribe Poeciliini share the following uniquely derived and unreversed features: (1) ascending process of premaxilla short and pointed [12-2**]; (2) presence of a curved and forward directed process on ventral surface of dentary [15-1**]; (3) tooth plates of third and fourth pharingobranchials fused, forming a elongate structure with teeth regularly distributed [26-1**]; and (4) fifth ceratobranchial wide and bearing teeth regularly distributed [28-1**].

Additionally, they can be diagnosed by the following not uniquely derived and/or reversed features: (1) premaxillary symphysis elevated [13-1*]; (2) teeth compressed [21-1*]; (3) five branchiostegal rays [22-0]; (4) toothless fourth ceratobranchial [27-1]; (5) absence of spines on subdistal segments of R3 [108-0]; and (6) absence of a dark stripe on median portion of dorsal fin [137-0].

Composition. Tribes: Poeciliini, Girardinini and Cnesterodontini

Distribution. North, Central and South America.

Tribe Girardinini Hubbs, new usage

[Clade 116]

Girardinini Hubbs, 1924: 9. Type-genus: Girardinus Poey, 1854.

Diagnosis. Girardinins can be diagnosed by the following not uniquely derived and/or reversed features: (1) width of first pelvic-fin ray in adult males decreasing abruptly at distal portion, distal slender portion long [41-1]; (2) distal portion of second and third gonactinosts fused [71-1]; (3) more distal elements of R6 branches totally fused [127-2]; and (4) dark patch of pigmentation along R3 [138-1].

Composition. Genera Girardinus, Phallichthys, Xenophallus, Poeciliopsis, Phalloptychus.

Distribution. USA, Mexico, Cuba, Belize, Guatemala, Honduras, Costa Rica, Panama, Colombia, and Brazil.

\section{Girardinus Poey}

Girardinus Poey, 1854: 383. Type species: Girardinus metallicus Poey, 1854. Type by monotypy. Gender: masculine.

Glaridodon Garman, 1895: 40. Type species: Girardinus uninotatus Poey, 1861. Type by original designation. Not available; name preoccupied in fossil Synapsida. Gender: masculine.

Glaridichthys Garman, 1896: 232. Type species: Girardinus uninotatus Poey, 1861. Type by being a replacement name for Glaridodon Garman, 1895 preoccupied in fossil Reptilia. Gender: masculine.

Toxus Eigenmann, 1903: 226. Type species: Toxus riddlei Eigenmann, 1903. Type by original designation. Gender: masculine.

Allodontium Howell Rivero \& Rivas, 1944: 17. Type species: Heterandria cubensis Eigenmann, 1904. Type by original designation. Gender: neuter.

Dactylophallus Howell Rivero \& Rivas, 1944: 15. Type species: Girardinus denticulatus Garman, 1895. Type by original designation. Gender: masculine.

Composition. Girardinus creolus Garman, G. cubensis (Eigenmann), G. denticulatus Garman, G. falcatus (Eigenmann), G. metallicus Poey, G. microdactylus Rivas, G. uninotatus Poey.

\section{Distribution. Cuba.}

\section{Phallichthys + Xenophallus + Poeciliopsis + Phalloptychus}

[Clade 113]

Diagnosis. Members of this clade can be diagnosed by the following not uniquely derived and/or reversed features: (1) parietals short restricted to the epiotic region, not reaching sphenotic anteriorly [2-1]; (2) epiotic process long extending beyond first pleural rib [3-0]; (3) ascending process of parasphenoids in adults long, contacting pterosphenoids [200]; (4) first proximal radial of dorsal fin in adult males located between neural spines of $10^{\text {th }}$ and $11^{\text {th }}$ vertebrae [62-4]; (5) adult females with first proximal radial of dorsal fin located between neural arches of $10^{\text {th }}$ and $11^{\text {th }}$ vertebrae [63-2]; (6) absence of a basal process on first gonactinost [69-0]; (7) complete fusion of second and third gonactinosts [72-1]; (8) lateral process on base of fifth middle anal-fin radial in adult males asymmetrical [79-3]; (9) middle anal-fin radials 5, 6, and 7 in adult males asymmetrical (right lateral projection more compressed and much larger than left one) [80-1]; (10) anal fin asymmetrical in adult males [87-1]; (11) more distal elements of R6 branches partially fused [127-1]; and (12) hypural plate bipartite [131-2].

\section{Phallichthys Hubbs}

Phallichthys Hubbs 1924: 10. Type species: Poeciliopsis isthmensis, Regan 1913. Type by original designation. Gender: masculine.

Composition. Phallichthys amates (Miller); P. fairweatheri Rosen \& Bailey, P. quadripunctatus Bussing, P. tico Bussing. 
Distribution. Belize and northern Guatemala to Costa Rica and western Panama (Atlantic drainages). Introduced on $\mathrm{Pa}$ cific Slope of Costa Rica.

\section{Xenophallus + Poeciliopsis + Phalloptychus [Clade 110]}

Diagnosis. Xenophallus, Poeciliopsis, and Phalloptychus share the following uniquely derived and unreversed feature: (1) convergent anal-fin proximal radials of females $[66-2 * *]$.

Additionally, this clade can be diagnosed by the following not uniquely derived and/or reversed features: (1) width of first pelvic-fin ray in adult males decreasing abruptly at distal portion, distal slender portion long [41-1]; (2) ligastyle with one axis [46-1]; (3) females with 10 anal-fin rays [65-1]; (4) distal portion of third and fourth gonactinosts completely fused [74-1]; (5) absence of an anterior process on base of fifth middle anal-fin radial in adult males [78-0]; (6) males with 10 anal-fin rays [85-0]; (7) absence of an elongate and dorsal protuberance along $\mathrm{R} 4 \mathrm{p}$ (just behind retrorse spines series) of anal fin in adult males [118-0]; and (8) more distal elements of R6 branches totally fused [127-2].

\section{Xenophallus Hubbs}

Xenophallus Hubbs, 1924: 10 [footnote]. Type species: Gambusia umbratilis Meek, 1912. Type by original designation. Gender: masculine.

Composition. Xenophallus umbratilis (Meek)

Distribution. Costa Rica (Atlantic Drainages).

\section{Poeciliopsis + Phalloptychus}

[Clade 105]

Diagnosis. Poeciliopsis and Phalloptychus share the following uniquely derived and unreversed features: (1) ventral process of anguloarticular short, not extending anterior to where anguloarticular overlaps dentary; [18-1**]; (2) gonapophysis of vertebra 14 very curved in adult males [52-1**]; and (3) branches of R6a and R6p completely fused [126-2**].

Additionally, this clade can be diagnosed by the following not uniquely derived and/or reversed features: (1) anterior tip of basipterygium in adult males clearly round and keeled [373]; (2) presence of a lateral keel in basipterygium in adult males [38-1]; (3) first proximal radial of dorsal fin in adult males located between neural spines of $12^{\text {th }}$ and $13^{\text {th }}$ vertebrae [62-0]; and (4) adult females with first proximal radial of dorsal fin located between neural arches of $12^{\text {th }}$ and $13^{\text {th }}$ vertebrae [63-0].

\section{Poeciliopsis Regan}

Poeciliopsis Regan, 1913: 996. Type species: Poecilia presidionis Jordan \& Culver, 1895. Type by subsequent designation. Gender: feminine.
Leptorhaphis Regan, 1913: 998. Type species: Gambusia infans Woolman, 1894. Type by monotypy. Gender: feminine.

Aulophallus Hubbs, 1926: 64, 69. Type species: Poecilia elongata Günther, 1866. Type by original designation. Gender: masculine.

Poecilistes Hubbs, 1926: 63, 68. Type species: Heterandria lutzi Meek, 1904. Type by original designation. Gender: masculine.

Composition. Poeciliopsis baenschi Meyer, Radda, Riehl \& Feichtinger, P. balsas Hubbs, P. catemaco Miller, $P$. elongata (Günther); P. fasciata (Meek); P. gracilis (Heckel), P. hnilickai Meyer \& Vogel, P. infans (Woolman), $P$. latidens (Garman), P. lucida Miller, P. lutzi (Meek); $P$. monacha Miller, $P$. occidentalis (Baird \& Girard), $P$. paucimaculata Bussing, P. presidionis (Jordan \& Culver), $P$. prolifica Miller, P. retropinna (Regan), P. scarlli Meyer, Riehl, Dawes \& Dibble, P. turneri Miller, P. turrubarensis (Meek); P. viriosa Miller.

Distribution. Southern USA to Colombia (Pacific drainages), and southeastern Mexico, Guatemala, and Honduras (Atlantic drainages).

\section{Phalloptychus Eigenmann}

Phalloptychus Eigenmann, 1907: 426, 430. Type species: Girardinus januarius Hensel, 1868. Type by original designation. Gender: masculine.

Composition. Phalloptychus eigenmanni Henn, $P$. januarius (Hensel), P. iheringii (Boulenger).

Distribution. Brazil: rio Catu in Alagoinhas (Bahia) and coastal drainages from Rio de Janeiro to Rio Grande do Sul.

\section{Tribe Poeciliini + Tribe Cnesterodontini [Clade 115]}

Diagnosis. Poeciliins and Cnesterodontins can be diagnosed by the following not uniquely derived and/or reversed features: (1) parietals absent [2-2]; (2) anterior tip of basipterygium in adult males approximately triangular and round [37-0]; (3) ligastyle with one axis [46-1]; (4) pleural ribs associated with haemal arches in males [601]; (5) pleural ribs associated with haemal arches in females [61-1]; (6) absence of an anterior convex expansion of second gonactinosts [70-0]; (7) absence of an anterior process on base of fifth middle anal-fin radial in adult males [78-0]; (8) males with 10 anal-fin rays [85-0]; and (9) absence of an elongate and dorsal protuberance along $\mathrm{R} 4 \mathrm{p}$ (just behind retrorse spines series) of anal fin in adult males [118-0]. 


\section{Tribe Poeciliini Bonaparte, new usage [Clade 112]}

Poecilini Bonaparte, 1831: 94, unavailable name; preoccupied in Coleoptera.

Poeciliini Bonaparte, 1831. Type-genus Poecilia Bloch \& Schneider, 1801.

Diagnosis. Poeciliins can be diagnosed by the following not uniquely derived and/or reversed features: (1) notch on dentary [16-1]; (2) ascending process of parasphenoids in adults long, contacting pterosphenoids [20-0]; (3) second gonapophysis forming an angle of 45-70 degrees relative to vertebral column [54-1]; (4) third gonapophysis forming an angle of 35-70 degrees relative to vertebral column [55-1]; (5) first proximal radial of dorsal fin in adult males located between neural spines of $11^{\text {th }}$ and $12^{\text {th }}$ vertebrae [62-6]; (6) adult females with first proximal radial of dorsal fin located between neural arches of $8^{\text {th }}$ and $9^{\text {th }}$ vertebrae [63-7*]; (7) 10 or more dorsal-fin rays (males and females) [64-0]; and (8) dark stripe present on median portion of dorsal fin [137-1].

Composition. Genera Poecilia, "Poecilia" reticulata, Xiphophorus, Limia, Pamphorichthys, Micropoecilia, Quintana, Carlhubbsia, and Xenodexia.

Distribution. North, Central and South America.

\section{Quintana + Carlhubbsia}

[Clade 109]

Diagnosis. Quintana and Carlhubbsia share the following not uniquely derived and/or reversed features: (1) parietals short restricted to the epiotic region, not reaching sphenotic anteriorly [2-1]; (2) epiotic process long extending beyond first pleural rib [3-0]; (3) anal-fin proximal radials divergent in females [66-1]; (4) anal fin asymmetrical in adult males [87-1]; and (5) serrae on R5p [125-1].

\section{Quintana Hubbs}

Quintana Hubbs, 1934: 2. Type species: Quintana atrizona Hubbs, 1934. Type by original designation. Gender: feminine.

Composition. Quintana atrizona, Hubbs.

Distribution. Western Cuba.

\section{Carlhubbsia Whitley}

Allophallus Hubbs, 1936: 232. Type species: Allophallus kidderi Hubbs, 1936. Type by original designation. Gender: masculine.

Carlhubbsia Whitley, 1951: 67. Type species: Allophallus kidderi Hubbs, 1936. Type by being a replacement name. Gender: feminine.
Composition. Carlhubbsia kidderi (Hubbs), and C. stuarti Rosen \& Bailey.

Distribution. Carlhubbsia is recorded only from the drainage of the río Polochic and Lake Izabal (Guatemala), whereas C. kidderi is known to occur in the río Champotón (Mexico) and in the drainages of río San Pedro de Mártir and río de la Pásion (Guatemala) (Rosen \& Bailey, 1959).

\section{Xiphophorus + Xenodexia + Poecilia + Limia + Pamphorichthys + Micropoecilia + "Poecilia" Clade [108]}

Diagnosis. Members of this clade share the following uniquely derived and unreversed feature: (1) Lateral wings on segments of R3 symmetrical [109-1**]. Additionally, members of this clade can be diagnosed by the following not uniquely derived and/or reversed features: (1) pelvicfin in adult males long, second ray extending beyond the end of anal-fin base [34-1]; (2) pelvic girdle of males very posterior, anterior border of basipterygium posterior to the posterior border of cleithrum [35-0]; (3) anterior tip of basipterygium in adult males clearly pointed [37-1]; (4) pleural ribs in adult males almost straight, slightly curving forward and not converging to the same point towards pelvic girdle [59-0]; and (5) spines on subdistal segments of R3 retrorse [108-2].

\section{Xiphophorus Heckel}

Xiphophorus Heckel, 1848: 291. Type species: Xiphophorus hellerii Heckel, 1848. Type by subsequent designation. Gender: masculine.

Platypoecilus Günther, 1866: 350. Type species: Platypoecilus maculatus Günther, 1866. Type by monotypy. Gender: masculine.

Composition. Xiphophorus alvarezi Rosen, X. andersi Meyer \& Schartl, X. birchmanni Lechner \& Radda, X. clemenciae Alvarez, $X$. continens Rauchenberger, Kallman \& Morizot, X. cortezi Rosen, X. couchianus (Girard), X. evelynae Rosen, $X$. gordoni Miller \& Minckley, X. hellerii Heckel, X. kallmani Meyer \& Schartl, X. kosszanderi Meyer \& Wischnath, X. maculatus (Günther); X. malinche Rauchenberger, Kallman \& Mozirot, X. mayae Meyer \& Schartl, X. meyeri Schartl \& Schröder, X. milleri Rosen, X. mixei Kallman, Walter, Morizot \& Kazianis, X. montezumae Jordan \& Snyder, X. monticolus Kallman, Walter, Morizot \& Kazianis. X. multilineatus Rauchenberger, Kallman \& Morizot, X. nezahualcoyotl Rauchenberger, Kallman \& Morizot, X. nigrensis Rosen, X. pygmaeus Hubbs \& Gordon, $X$. signum Rosen \& Kallman, $X$. variatus (Meek); $X$. xiphidium (Gordon).

Distribution. Mexico to Belize (Atlantic drainages). 


\section{Xenodexia +Poecilia + Limia + Pamphorichthys + Micropoecilia + "Poecilia" Clade [104]}

Diagnosis. Members of this clade share the following uniquely derived and unreversed feature: (1) wide groove dorsal to R5 [121-1**].

Additionally, this clade can be diagnosed by the following not uniquely derived and/or reversed features: (1) preorbital canal present and entirely closed, bearing four pores [9-0]; (2) adult females with first proximal radial of dorsal fin located between neural arches of $10^{\text {th }}$ and $11^{\text {th }}$ vertebrae [63-2]; (3) absence of a basal process on first gonactinost [69-0]; (4) fusion of anal-fin posterior median radials ( $5^{\text {th }}$ to last one) in adult males to respective proximal radials [77-1]; (5) distal segments of $\mathrm{R} 4 \mathrm{p}$ posterior to serrae deeper than wide [115-1*]; (6) keel on posterior ventral surface of R5 formed by the projection of R5 toward R4 [119-1*]; and (7) hypural plate completely fused [131-0].

\section{Xenodexia Hubbs}

Xenodexia Hubbs, 1950: 8. Type species: Xenodexia ctenolepis Hubbs, 1950. Type by original designation. Gender: feminine.

\section{Composition. Xenodexia ctenolepis Hubbs.}

Distribution. Guatemala, Alta Vera Paz in río Finca, tributary to the río Negro (río Chixoy) which lower down becomes the río Salinas of the río Usumacinta basin.

\section{Poecilia + Limia + Pamphorichthys + Micropoecilia + "Poecilia" Clade [99]}

Diagnosis. Members of this clade share the following uniquely derived and unreversed features: (1) two (rarely one) welldeveloped gonapophyses [48-2**]; and (2) functional gonapophyses located between vertebrae 13 to 15 , but never on vertebra 16 [49-2**].

Additionally, this clade can be diagnosed by the following not uniquely derived and/or reversed features: (1) ligastyle absent [46-0]; (2) Hollister's foramen on first or second gonapophysis [51-1*]; (3) eight dorsal-fin rays (males and females) [64-2]; (4) nine anal-fin rays in females [65-3*]; and (5) presence of a palp in subdistal segments of R3 [88-1].

\section{Poecilia + Limia Clade [93]}

Diagnosis. Poecilia and Limia share the following not uniquely derived and/or reversed features: (1) parietals short restricted to the epiotic region, not reaching sphenotic anteriorly [2-1]; (2) posterior supraorbital canal closed [5-2]; (3) width of first pelvic-fin ray in adult males decreasing abruptly at distal portion, distal slender portion long [41-1]; and (4) second gonapophysis forming an angle of 15-45 degrees relative to vertebral column [54-0].

\section{Poecilia Bloch \& Schneider}

Poecilia Bloch \& Schneider, 1801: 452. Type species: Poecilia vivipara Bloch \& Schneider, 1801. Type by subsequent designation. Gender: feminine.

Mollienesia Lesueur, 1821: 3. Type species: Mollienesia latipinna Lesueur, 1821. Type by monotypy. Gender: feminine.

Alazon Gistel, 1848: X. Type species: Poecilia vivipara Bloch \& Schneider, 1801. Type by being a replacement name. Gender: masculine.

Allopoecilia Hubbs, 1924: 11. Type species: Girardinus caucanus Steindachner, 1880. Type by original designation. Gender: feminine.

Neopoecilia Hubbs, 1924: 11. Type species: Neopoecilia holacanthus Hubbs, 1924. Type by original designation. Gender: feminine.

Psychropoecilia Myers, 1935: 311. Type species: Platypoecilus dominicensis Evermann \& Clark, 1906. Type by original designation. Gender: feminine.

? Lembesseia Fowler, 1949: 267. Type species: Lembesseia parvianalis Fowler, 1949. Type by original designation. Gender: feminine.

Curtipenis Rivas \& Myers, 1950: 289. Type species: Mollienesia elegans Trewavas, 1948. Type by original designation. Gender: masculine.

Composition. Poecilia amazonica Garman, P. boesemani Poeser, $P$. butleri Jordan, $P$. catemaconis Miller, $P$. caucana (Steindachner), P. caudofasciata (Regan), P. chica Miller, P. elegans (Trewavas), P.formosa (Girard), P. gillii (Kner); $P$. hispaniolana Rivas, P. koperi Poeser, P. kykesis Poeser, $P$. koperi Poeser, P. latipinna (Lesueur), P. latipunctata Meek, $P$. marcellinoi Poeser, $P$. maylandi Meyer, P. mechthildae Meyer, Etzel \& Bork, P. mexicana Steindachner, P. orri Fowler, $P$. petenensis Günther, $P$. salvatoris Regan, $P$. sphenops Valenciennes, $P$. sulphuraria (Alvarez), $P$. teresae Greenfield, $P$. vandepolli Van Lidth de Jeude, $P$. velifera (Regan); P. vivipara Bloch \& Schneider, P. wandae Poeser, and $P$. zonata Nichols.

Distribution. North, Central, and South America.

\section{Limia Poey}

Limia Poey, 1854: 382, 390. Type species: Limia cubensis Poey, 1854. Type by subsequent designation. Gender: feminine.

Acropoecilia Hilgendorf, 1889: 52. Type species: Poecilia tridens Hilgendorf, 1889. Type by monotypy. Gender: feminine.

Odontolimia Rivas, 1980: 29. Type species: Limia grossidens Rivas, 1980. Type by original designation. Gender: feminine.

Pseudolimia Poeser 2002: 54. Type species: Limia heterandria Regan 1913. Type by original designation (also monotypic). Gender: feminine. 
Composition. Limia caymanensis Rivas \& Fink, L. dominicensis (Valenciennes); L. fuscomaculata Rivas, L. garnieri Rivas, L. grossidens Rivas, L. heterandria Regan, L. immaculata Rivas, L. melanogaster (Günther), L. melanonotata Nichols \& Myers, L. miragoanensis Rivas, L. nicholsi Myers, L. nigrofasciata Regan, L. ornata Regan, L. pauciradiata Rivas, L. perugiae (Evermann \& Clark), L. rivasi Franz \& Burgess, L. sulphurophilia Rivas, L. tridens (Hilgendorf), L. versicolor (Günther), L. vittata (Guichenot), and L. yaguajali Rivas.

Distribution. Cayman Islands, Haiti, Dominican Republic, Haiti, Jamaica, Cuba, and Venezuela.

\section{Pamphorichthys + Micropoecilia + "Poecilia" Clade [92]}

Diagnosis. Members of this clade can be diagnosed by the following not uniquely derived and/or reversed features: (1) absence of an epiotic process [3-3]; (2) absence of a notch on dentary [16-0]; (3) gonactinost complex approximately perpendicular to body longitudinal axis [68-1]; (4) absence of an anterior convex expansion of second gonactinost [70-1]; (5) R6a and R6p not fused [126-0]; (6) more distal elements of R6 branches not fused [127-0]; and (7) less than nine caudal-fin rays in contact with the hypural plate [132-0].

\section{Pamphorichthys Regan}

Pamphorichthys Regan, 1913: 1003. Type species: Heterandria minor Garman, 1895. Type by monotypy. Gender: masculine.

Pamphoria Regan, 1913: 1003. Type species: Cnesterodon scalpridens Garman, 1895. Type by monotypy. Gender: feminine.

Parapoecilia Hubbs, 1924: 11. Type species: Limia hollandi Henn, 1916. Type by original designation. Gender: feminine.

Composition. Pamphorichthys araguaiensis Costa, $P$. hasemani (Henn); P. hollandi (Henn); P. minor (Garman); $P$. scalpridens (Garman).

Distribution. Drainages of the rio Tocantins basin, rio Xingu. rio Paraguai, rio São Francisco, rio Parnaíba, rio Amazonas, and rio Tapajós (Figueiredo, 1997).

\section{Micropoecilia + "Poecilia" reticulata Clade [87]}

Diagnosis. Micropoecilia and "Poecilia" share the following not uniquely derived and/or reversed features: (1) preorbital canal present and partially closed bearing two upper pores and a lower deep groove [9-1]; (2) anterior tip of basipterygium in adult males approximately triangular and round [37-0]; (3) first gonapophysis forming an angle of 5-15 degrees relative to vertebral column [53-2]; (4) second gonapophysis forming an angle of zero-15 degrees relative to vertebral column [54-3]; (5) distal portion of third and fourth gonactinosts separate, except by tip of gonactinost [74-2]; (6) gonactinost 5 fused to gonactinost complex [81-1]; (7) spines on subdistal segments of R3 retrorse [108-2]; (8) distal segments of R4p posterior to serrae wider than deep [115-0]; (9) four to seven subdistal retrorse spines on R4p [116-2]; (10) absence of a keel on posterior ventral surface of R5 formed by the projection of R5 toward R4p [119-0]; and (11) hypural plate partially fused with an elongate aperture [131-1].

\section{Micropoecilia Hubbs}

Micropoecilia Hubbs, 1926: 73. Poecilia vivipara parae Eigenmann, 1894. Type by original designation. For purposes of the type species, the subspecies parae is elevated to species level; type not $P$. vivipara.

Recepoecilia Whitley, 1951: 68. Poecilia vivipara parae Eigenmann, 1894. Type by being a replacement name. For purposes of the type species, the subspecies $P$. v. parae is elevated to species level; type not $P$. vivipara. Unneeded replacement for Micropoecilia Hubbs, 1926 not preoccupied by Micropoecila Kraatz, 1880 in Coleoptera.

Composition. Micropoecilia minima (Costa \& Sarraf), $M$. picta (Regan), M. parae (Eigenmann), M. bifurca (Eigenmann), and M.branneri (Eigenmann).

Distribution. Drainage of the rio Amazonas, rio Guamá basin, coastal drainages of Brazil, French Guyana, Guyana, and Suriname; Trinidad and Tobago.

Remarks. The tree topology placed "Poecilia" reticulata as the sister group of the Micropoecilia clade and far from the type-species of the genus, Poecilia vivipara. This fact brings taxonomic and nomenclatural implications, since the generic name Poecilia cannot be applied to the reticulata species. The most parsimonious action should be the merging of "Poecilia" reticulata with the genus Micropoecilia Hubbs, 1926.

"Poecilia" reticulata was originally described as Poecilia reticulata Peters, 1859 and Lebistes poecilioides De Fillipi, 1861 is considered a junior synonym. Lebistes poecilioides, whose types are lost, was described as a new genus and a new species. Since the name Lebistes is older than Micropoecilia it has priority and Micropoecilia should be considered a junior synonym of Lebistes. However, Poeser \& Isbrücker (2002) suggested, based on evidence on the original description of De Fillipi, that L. poecilioides is not equal to Poecilia reticulata. If it is the case, Lebistes cannot be a synonym of Micropoecilia. However, Eigenmann (1907) erected the genus Acanthophacelus for Poecilia reticulata, thus if Micropoecilia species and "Poecilia" reticulata are merged under the same generic name, Acanthophacelus Eigenmann, 1907 has priority over Micropoecilia Hubbs, 1926 and therefore should be resurrected and revalidated. Given that the types of Lebistes poecilioides are lost and that De 
Fillipi's description is probably not acurate and reliable, any nomenclatural action is premature and also depends upon a more inclusive phylogenetic analysis among members of the tribe Poeciliini. This analysis could address the question more thoroughly. At the moment, unless Lebistes poecilioides types or unquestionable evidence are found Lebistes poecilioides and Poecilia reticulata should be regarded Incertae Sedis in Poeciliinae.

\section{Tribe Cnesterodontini Hubbs, new usage} [Clade 111]

Cnesterodontini Hubbs, 1924: 8. Type-genus: Cnesterodon Garman, 1895

Diagnosis. Cnesterodontins share the following uniquely derived and unreversed features: (1) males with five pelvicfin rays [33-1**]; (2) pedicel in R3 united to R4 [90-1**]; (3) pedicel at tip of R3 [91-1**]; and (4) membranous appendix at tip of R3 [92-1**].

Additionally, the tribe Cnesterodontini can be diagnosed by the following not uniquely derived and/or reversed features: (1) absence of an epiotic process [3-3]; (2) posterior section of posterior remnant of infraorbital system opened into a groove [7-1]; (3) preorbital canal absent or opened, forming a very shallow groove [9-2]; (4) post-temporal unbranched [31-1]; (5) females with five pelvic-fin rays [44-1]; (6) pleural ribs 6, 7, and 8 in adult males curved forward converging to the same point towards pelvic girdle [59-2*]; (7) eight dorsal-fin rays (males and females) [64-2]; (8) adult males with anterior process on base of fifth middle anal-fin radial pointed and upward directed [78-1]; (9) membranous tip anterior to R4 and R5 curved downwards [110-1]; (10) small membranous tip anterior to R4 and R5 [111-1]; (11) four to seven subdistal retrorse spines on R4p [116-2]; and (12) expanded distal portion of R6 [128-1].

Composition. Genera Cnesterodon, Phallotorynus, and Phalloceros.

Distribution. Southern South America.

\section{Cnesterodon Garman}

Cnesterodon Garman, 1895: 43. Type-species: Poecilia decemmaculata Jenyns, 1842. Type by original designation. Gender masculine.

Gulapinnus Langer, 1913: 207. Type-species: Poecilia decemmaculata Jenyns, 1842. Type by monotypy. Gender masculine.

Composition. Nine species: Cnesterodon decemmaculatus (Jenyns), C. carnegiei Haseman, C. brevirostratus Rosa \& Costa, C. septentrionalis Rosa \& Costa, C. omorgmatos Lucinda \& Garavello, C. hypselurus Lucinda \& Garavello, $C$. raddai Meyer \& Etzel, Cnesterodon n. sp. A (a new species being described by Lucinda [in prep.]), and Cnesterodon $\mathrm{n}$. sp. B (a new species being described by Anza et al. [in prep.]).

Distribution. Rio Uruguai drainage, laguna dos Patos system, río Negro, río Salado, western drainages of Argentina and small coastal drainages of Uruguay and Argentina, upper portions of the rio Iguaçu and its upper tributaries, the headwaters of the rio Maquiné in the Tramandaí system, and the headwaters of rio Itajaí-Açu drainage, upper rio Araguaia drainage, rio Paranapanema basin, rio Paraguai and lower rio Paraná drainages, upper rio Iporanga tributary of the rio Ribeira de Iguape.

\section{Phallotorynus + Phalloceros Clade [106]}

Diagnosis. Phallotorynus and Phalloceros share the following not uniquely derived and/or reversed features: (1) halves of supraoccipital process bifid, outer half larger than inner half [4-2*]; (2) ascending process of premaxilla short and truncate [12-3]; (3) premaxillary symphysis not elevate [13-0]; (4) gonactinost complex approximately perpendicular to body longitudinal axis [68-1]; (5) lateral flanges on ventral portion of anal-fin radial 4 in adult males present and cleft dorsally forming separate dorsally directed processes [75-2]; (6) less than nine caudal-fin rays in contact with the hypural plate [132-0]; (7) dark stripe present on median portion of dorsal fin [137-1]; and (8) dark patch of pigmentation along R3 [138-1].

\section{Phalloceros Eigenmann}

Phalloceros Eigenmann, 1907: 427, 431. Type species: Girardinus caudimaculatus Hensel, 1868. Type by original designation. Gender: masculine.

Composition. Phalloceros caudimaculatus (Hensel), plus 21 new species being described by Lucinda (in prep.).

Distribution. Upper rio Tocantins drainage, coastal and inland drainages from Bahia (Brazil), southward to Uruguay, Argentina, and Paraguay.

\section{Phallotorynus Henn}

Phallotorynus Henn, 1916: 126. Type species: Phallotorynus fasciolatus Henn, 1916. Type by monotypy. Gender: masculine.

Composition. Phallotorynus fasciolatus Henn, $P$. jucundus Ihering, $P$. victoriae Oliveros, plus three new species being described by Lucinda et al. (in prep.).

Distribution. Rio Paraíba do Sul drainage and rio ParanáParaguay drainage. 


\section{Discussion}

The classification of the subfamily Poeciliinae. The classification of the subfamily Poeciliidae has suffered many modifications even before the establishment as a distinct subfamily (see historical accounts). Preterit authors attempted to define the Poeciliinae in the absence of a cladistic hypothesis. Eigenmann (1907) and Regan (1911) were the first to define the Poeciliinae based on exclusive characters: absence of exoccipital condyles and male anal-fin rays modified into a gonopodium. Non-cladistic diagnoses and non-cladistic speculations of relationships were provided by different authors (e.g. Hubbs, 1924, 1926; Howell Rivero \& Hubbs, 1936; Rosen, 1952; Rosen \& Gordon, 1953; Rosen \& Bailey, 1959; Rosen, 1967; Costa, 1991; Meyer, 1993; Meyer \& Etzel, 1996, 1998; Meyer \& Radda, 2000; Meyer \& Etzel, 2001a, 2001b; Meyer \& Schartl, 2002). Non-cladistic classifications were also proposed (e.g. Hubbs, 1924, 1926; Rosen \& Bailey, 1963). However, these classifications did not necessarily communicate phylogenetic relationships.

Hubbs (1924) was the first to present a formal classification for the subfamily Poeciliinae. Hubbs' (1924) classification is somewhat congruent with the classification proposed herein. The naturalness of the groups Tomeurini, Alfarini, Gambusiini, Poeciliopsinae, and Poeciliinae proposed by Hubbs are corroborated by our phylogenetic analysis. The classification of Hubbs (1924) has suffered subsequent, little modifications, which mainly accounted for the inclusion of new genera on the tribes (Hubbs, 1926; Hubbs, 1931; Hubbs, 1936; Hubbs \& Howell Rivero, 1936; Rosen, 1950 and Rosen, 1952). The most striking partial congruence among these classifications and the classification herein proposed is that of Poeciliopsinae Hubbs and our tribe Girardinini. Hubbs (1924) suggest that Leptorhaphis [=Poeciliopsis], Phallichthys, Xenophallus, Poeciliopsis, and Phalloptychus were closed related, creating the name Poeciliopsinae for these genera. Hubbs (1926) added Poecilistes [=Poeciliopsis], and Aulophallus [=Poeciliopsis] to this group. The subfamily Poeciliopsinae proposed by Hubbs $(1924,1926)$ is very similar to our tribe Girardinini, differing only by the inclusion of the genus Girardinus in our tribe (we employed the name Girardinini Hubbs, 1924: 9; which has page priority over Poeciliopsini Hubbs, 1924: 10, although this is not necessarily obligatory - see Article 64 on fourth edition of the ICZN, 1999). Hubbs $(1924,1926)$ allocated Girardinus in his new tribe Girardinini together with Glaridichthys and Toxus (junior synonyms of Girardinus).

Contrarily to us, Rosen \& Bailey (1959) sustained the idea that Poeciliopsiinae is not a natural group and should therefore be dissolved. They discussed the gonopodium asymmetry of the Poeciliopsinae and believed that characters related to gonopodium folding were highly adaptive and may had evolved independently more than once within the subfamily. Theses authors also supposed that Poeciliopsis and Phallichthys form a natural group and that Carlhubbsia is related to Quintana and Giradinus. Our results are contrary to Rosen \& Bailey's (1959) assumptions, except for the statement that Carlhubbsia is related to Quintana. The dissolution of the Poeciliopsinae was formally put forward by Rosen \& Bailey's (1963) new poeciliin classification. Members of this group were allocated in two different tribes: Phalloptychus in Cnesterodontini, Poeciliopsis, Phallichthys, and Xenophallus in Heterandriini. Expectedly Carlhubbsia, Quintana, and Giradinus were unified in a tribe Girardinini.

The classification of Rosen \& Bailey (1963) also differs from ours in the position of genera Alfaro and Priapella in the tribe Poeciliini and the position of Brachyrhaphis in the tribe Gambusiini. We proposed Alfaro, Brachyrhaphis, and Priapella as type-genera of monotypic, basal tribes. Additionally, the tribes Girardinini and Heterandriini of Rosen \& Bailey (1963) differ substantially from ours. This incongruence can be explained by the fact that diagnoses of supraspecific groups by Rosen \& Bailey (1963) (and also the statements of Rosen \& Bailey, 1959) were made in the absence of cladistic methodology and therefore not necessarily reflect phylogenetic relationships. Rosen (1979: 278-279) was aware of this and recognized the fragility of Rosen and Bailey's classification, when stated: " (...) it should be noted that the diagnoses of genera and other supra-specific groups in Rosen and Bailey were designed as phenetic statements of overall similarity. In short, little attention was paid to find unique characters for defining the taxa and only an implicit effort was made to interpret the different states of a character as primitive or derived. (...)."

The advent of cladistic methodology has brought some improvement towards the comprehension of poeciliine relationships. Some authors addressed the relationships of smaller groups of the Poeciliinae (e.g. Rosen, 1979; Rauchenberger, 1989; Rosa \& Costa, 1993; Rauchenberger et al., 1990; Meyer et al., 1994; Mojica et al., 1997; Rodriguez, 1997; Ptaceck \& Breden, 1998; Marcus \& McCune, 1999; Breden et al., 1999; Hamilton, 2001; Mateos et al., 2002; Poeser, 2003; Kallmann et al., 2004), whereas others coped with higher taxa (Parenti, 1981; Meyer \& Lydeard, 1993; Costa, 1996, 1998; Ghedotti, 2000). However, no phylogenetic study has simultaneously analyzed the relationships among representatives of all poeciliine genera. The only comprehensive study is the classic revision of the "Poeciliidae" by Rosen \& Bailey (1963), which did not deal with cladistic methodology.

The proposed phylogeny and classification attempted to include representatives of all poeciliine genera. They are consistent with the results of the phylogenies proposed by Breden et al. (1999), and Figueiredo (1997) for Poecilia and its allies. On the other hand, the phylogenetic hypothesis of Rauchenberger (1989), Rodriguez (1997), and Ghedotti (2000) are partially congruent with the present results. Probably part of the incongruence can be explained by the fact that these phylogenetic studies had been performed for different subunits of the Poeciliinae.

Rauchenberger (1989) proposed: (1) Gambusia and Belonesox as sister groups and (2) that clade as the sistergroup of Brachyrhaphis. The former proposal, but not the 
later was corroborated by our results. Our hypothesis support Gambusia and Belonesox more closely related to Pseudopoecilia, Neoheterandria, and Scolichthys than to Brachyrhaphis. Thus, we modified the usage of the name Gambusiini sensu Rauchenberger (1989), employing it to refer to a clade composed of Gambusia, Belonesox, Pseudopoecilia, Neoheterandria, and Scolichthys.

Costa (1991) suggested the monophyly of the group embracing Pamphorichthys, Poecilia, Limia, Xiphophorus, Cnesterodon, Phalloceros, Phallotorynus, Phalloptychus, Priapichthys, Poeciliopsis, Priapella, Quintana, Carlhubbsia, Xenodexia, and Phallichthys supported by four putative synapomorphies (see our characters 12, 15, 26 and 28). This is partially corroborated by our results. The current phylogenetic analysis supports these features as a uniquely derived and unreversed synapomorphies for the supertribe Poeciliini [Clade 119], which in addition to the genera above (except Priapichthys and Priapella), also comprises Girardinus, Xenophallus, and Micropoecilia.

Rodriguez's (1997) conclusions are also consistent with ours. This author was unable (like us) to find shared derived characters uniting Alfaro and Priapella together with Xiphophorus, Poecilia (including Micropoecilia), Limia, and Pamphorichthys as suggested by Rosen \& Bailey (1963). Rodriguez (1997) hypothesized a monophyletic Poeciliini composed of Xiphophorus, Poecilia (including Micropoecilia), Limia, and Pamphorichthys on the basis of three synapomorphies: (1) a wide groove dorsal to R5; (2) long pelvic-fin in adult males, second ray surpassing the end of anal-fin base; and (3) compressed external teeth. However, none of the synapomorphies above are exclusive to this fish assemblage and are not useful as diagnostic characters. The presence of a wide groove dorsal to R5 is also observed in Xenodexia and herein interpreted as a uniquely derived and unreversed synapomorphy for a broader clade containing Xenodexia, Poecilia, Limia, Pamphorichthys, Micropoecilia, and "Poecilia" [Clade 104]. A long second pelvic-fin ray surpassing the end of anal-fin base is also present in Xenophallus and therefore is hypothesized to have been independently acquired by Xenophallus and by the ancestor of a clade comprising Xiphophorus, Xenodexia, Poecilia, Limia, Pamphorichthys, Micropoecilia, and "Poecilia" [Clade 108]. Presence of compressed teeth is herein interpreted as synapomorphic for a more encompassing clade, i. e. the supertribe Poeciliini [Clade 119] (with a reversal in Cnesterodon brevirostratus $+C$. septentrionalis clade).

Ghedotti (2000) was the first to propose a phylogenetic classification scheme for the group, despite relying his conclusions on a limited sample (representatives of twelve poeciliine genera). This is understandable, however, given that the main focus of Ghedotti's paper was the relationships among members of a more encompassing group: the superfamily Poecilioidea. Except for the recognition of Alfaro and Priapella as basal taxa, Ghedotti's (2000) hypothesis is only partially harmonious with ours. It differs mainly by the placement of Tomeurus as a highly derived poeciliine (in the tribe Cnesterodontini), whereas our results support the assump- tion that Tomeurus is the most basal poeciliine; the sistergroup of the remaining members of the subfamily. The phylogenetic position of Tomeurus will be discussed in more detail below in the next section.

The goal of phylogenetic analyses is to continuously improve our knowledge of relationships. The purpose of a written classification is to communicate phylogenetic relationships. The proposed hypothesis of relationships and classification is only preliminary. Much of continued effort on taxonomy and phylogeny are still required towards a fully understanding of poeciliine history.

The Cnesterodontini. Questions related to the definition of the Cnesterodontini have long been based on the pre-cladistic diagnoses proposed by Hubbs $(1924 ; 1926)$ and Rosen \& Bailey (1963). The tribe Cnesterodontini as originally erected by Hubbs (1924) was composed of the genera Phalloceros, Cnesterodon, Phallotorynus, and Diphyacantha. The cnesterodontins were defined as poeciliines bearing "terminal segment of ray 3 forming a more or less specialized process" (Hubbs, 1924: 9). Hubbs (1926) added Darienichthys to the tribe. Later, Rosen \& Bailey (1963) recognized Diphyacantha and Darienichthys as junior synonyms of Priapichthtys and removed them from the Cnesterodontini, placing them in the tribe Heterandriini. Rosen \& Bailey (1963) also added Phalloptychus to the Cnesterodontini. These authors provided a diagnosis for the tribe based on the following characters: (1) absence of parietals; (2) unforked posttemporal; (3) long gonopodium; (4) unique type of gonopodial appendix at tip of R3; and (5) sexually dimorphic pleural ribs. Among these characters only "the unique type of gonopodium appendix" revealed useful in diagnosing the tribe. The loss of parietals is not unique to Cnesterodontini (sensu Rosen \& Bailey, 1963); it also occurs in Pseudopoecilia, Xenodexia, Pamphorichthys, Micropoecilia, and Poecilia reticulata. Besides Phalloceros do possess parietals. An unbranched post-temporal is exhibited by Scolichthys, Cnesterodon, Phallotorynus, and Phalloceros, but Phalloptychus possess a bifid post-temporal. Long gonopodium and sexually dimorphic pleural ribs are also not uniquely derived features shared by the Cnesterodontini sensu Rosen \& Bailey, 1963.

Ghedotti (2000) was the first to attempt a solution for the recognition or diagnosis of a monophyletic Cnesterodontini. He recognized Tomeurus as a member of the tribe Cnesterodontini. Ghedotti (2000: 53) diagnosed the Cnesterodontini by the following unique and unreversed synapomorphies: "(1) less than six pelvic-fin rays; (2) male pelvic girdle far anterior, under pectoral girdle; (3) paired bony cirri on the third anal-fin ray in males; and (4) dorsoposterior region of lachrymal very narrow."

Ghedotti (2000: 42) argued that "Most of this evidence for a basal position of Tomeurus is based on the morphology of the oral and pharyngeal jaws (T.S. 11, 13, 21, 38, 41) and most of the evidence for placement in the Cnesterodontini is based on the morphology of the gonopodium and gonopodial suspensorium (T.S. 45, 65, 72, 79, 85). The principle of parsimony supports the latter hypothesis and the homoplastic reversals 
in jaw structure possibly may be explained as a developmental by-product of reduced size. "However, our results (also based on global parsimony) support a rather different view, $i$. $e$. the morphology of the oral and pharyngeal jaws supports the assumption that Tomeurus is the most basal poeciliine, the sister-group of remaining members of the subfamily. We have different interpretations for Ghedotti's (2000) above evidence for Tomeurus placement in the Cnesterodontini, which are discussed below.

Ghedotti (2000; character 45) argued that absence of gonapophyses in Cnesterodon and Tomeurus are evidence of common exclusive ancestry. However, Cnesterodon species do exhibit gonapophyses, although rudimentary (see character 47). Following Ghedotti (2000; character 79), another putative synapomorphy for Tomeurus + Cnesterodon clade would be the posteriorly inclined position of the proximal anal-fin radials in males. Actually, in Tomeurus and Cnesterodon the gonactinost complex is very inclined backwards to an angle smaller than $45^{\circ}$ relative to the body longitudinal axis (state 68-0). However, on the basis of the present hypothesis of relationships, the condition in Cnesterodon is interpreted as a synapomorphic reversal and as plesiomorphic in Tomeurus. Ghedotti (2000; character 85) also proposed the lateral processes on ventral portions of sixth, seventh, and eighth proximal anal-fin radials in adult males contacting each other as synapomorphic for a clade Tomeurus + Cnesterodon . We believe these structures are non-homologous in both genera. These processes are entirely fused in Tomeurus forming a co-ossified structure, whereas in Cnesterodon lateral processes are present in posterior middle anal-fin rays of males (and not in the proximal ones), which are fused to their respective proximal radials.

Ghedotti (2000; character 65) proposed the male pelvic girdle far anterior, under pectoral girdle, as synapomorphic for the clade ((Tomeurus, Cnesterodon) Phalloceros, Phallotorynus)). Our analysis revealed the position of the pelvic girdle is not a useful character in diagnosing the Cnesterodontini. We identified five states of this character, which presented several independent acquisitions and reversals during the history of the Cyprinodontiformes (see character 35).

According to Ghedotti (2000; character 72), the presence of paired bony cirri on tip of R3 is a putative synapomorphy for a Cnesterodon + Phalloceros + Phallotorynus + Tomeurus clade. However, the bony cirri of our Cnesterodontini and Tomeurus seem to represent nonhomologous structures. The bony cirrus or pedicel of R3 of cnesterodontins is attached to R4 (character 90), whereas in Tomeurus, such structure is only attached to R3. Besides the pedicel of cnesterodontins is associated with a membranous appendix, whereas a membranous appendix associated with R3 is lacking in Tomeurus.

Ghedotti (2000) recognized the reduced number of pelvic fin-rays (less than six) as synapomorphic for Phalloceros, Phallotorynus, Cnesterodon, and Tomeurus. Our results support the hypothesis that such a reduction independently ap- peared in Tomeurus and in the ancestor of Phalloceros, Phallotorynus, and Cnesterodon.

The naturalness of a tribe Cnesterodontini composed of Phalloceros, Phallotorynus, and Cnesterodon, has already been suggested by Rosen (1959: 496): “(...) the morphological details of the osteocranium and some post-cranial bones of Cnesterodon nevertheless show conclusively that this genus and two others, Phalloceros and Phallotorynus, form a tightly knit group (...)." Rosen \& Kallman (1959) suggested that axial and appendicular skeleton resemblances between Tomeurus and Cnesterodon may be attributed to parallel evolution. These authors experimentally demonstrated that the loss or extreme reduction of gonapophyses in Tomeurus and Cnesterodon, respectively, is ontogenetically related to (and can be attributed) the far anterior position of the male pelvic girdle. These conclusions are very congruent to our results, which interpreted the position of the male pelvic girdle and the loss or extreme reduction of gonapophyses in Tomeurus and Cnesterodon as independently acquired.

The phylogenetic position of Tomeurus as the sister-group of remaining poeciliines brings to discussion the evolution of viviparity in the subfamily. Facultative viviparity in Tomeurus could be viewed as (1) a preliminary stage of viviparity towards true viviparity, a stage achieved by the ancestor of all remaining poeciliines; or (2) as an autapomorphic specialized condition of viviparity adaptable for different environmental conditions.

Most generic diagnostic characters for Cnesterodon, Phalloceros, and Phallotorynus provided by different authors (Eigenmann, 1907; Henn, 1916; Rosen \& Bailey, 1963; Oliveros, 1983; Rosa \& Costa, 1993) have been corroborated by this study. These generic characters as well as the relationships within the genera of the Cnesterodontini will be discussed in detail on oncoming studies that include the taxonomic revisions and phylogeny of the genera Cnesterodon, Phalloceros, Phallotorynus, and Phalloptychus (see Introduction for further details).

Biogeography of poeciliines. A clear biogeographic explanation for poeciliine distribution is not available, however, few considerations can be speculated. The subfamily Poeciliinae is distributed throughout the Americas. The most basal poeciliine Tomeurus gracilis occurs in coastal drainages of northern South America. The tribes Alfarini, Brachyrhaphini, Priapichthyini, and Priapellini have a mainly Central American distribution, whereas the Heterandriini, and Gambusiini have also invaded North American drainages. The genera Priapichthys, Pseudopoecilia, and Neoheterandria are distributed along Pacific drainages of Panama, Ecuador, Peru, and Colombia, which may represent an endemism area in South America. These genera may have differentiated in isolation provided by the elevation of the Andes. Girardinins are Central American fishes, except for the South American Phalloptychus. An explanation for the distribution of the Girardinini requires the assumption of either a broader preterit distribution, followed by extinction events or a dispersionist hypothesis. Poeciliins are distributed through- 
out the Americas. The most basal poeciliins (Quintana, Carlhubbsia, Xiphophorus, and Xenodexia) are CentralAmerican. Poecilia is widespread throughout the Americas, and Limia is confined to the Caribbean and Venezuela. Members of the Clade 92 (Micropoecilia, "Poecilia" reticulata, and Pamphorichthys) are restricted to South America. It seems reasonable to suppose that members of the tribe Poeciliini derived from a widespread ancient poeciliin, which suffered local differentiations resultant of local vicariant events giving rise to Quintana (in Cuba), Carlhubbsia (Guatemala and Mexico), Xiphophorus (Mexico to Belize), and Xenodexia (Guatemala), Limia (in the Caribbean and Venezuela) and members of Clade 92 in South America. Micropoecilia and "Poecilia" reticulata are distributed along northern coastal South American drainages of Venezuela, Guyana, Surinam, French Guyana and Brazil (Amapá and Pará States), whereas Pamphorichthys is distributed in rio Paraguai basin and northern drainages of Brazil (Tocantins, Xingu, São Francisco, Parnaíba, Amazonas, and Tapajós). Since Micropoecilia + "Poecilia" reticulata and Pamphorichthys are sister groups, it can be hypothesized that the ancestor of these fishes inhabit a huge ancient area in northern South American which was split in two areas, which represent the current distribution of Micropoecilia and Pamphorichthys. Cnesterodontins are endemic to southern South America.

The pattern of distribution of subsets of the subfamily Poeciliinae may help to tentatively identify putative areas of endemism for poeciliines in the American continent. Those areas are: (1) southern North America; (2) Cuba; (3) the Caribbean and Venezuela; (4) inland Central America; (5) pacific drainages of Panama, Colombia, Ecuador and Peru; (6) coastal drainages of northern South America along the Venezuela, Guyana, Suriname, French Guyana, and Brazil (Amapá and Pará States); (7) Paraguay River basin and northern drainages of Brazil (Tocantins, Xingu, São Francisco, Parnaíba, Amazonas, and Tapajós); and (8) southern South American drainages.

\section{Acknowledgements}

For loan of specimens we are deeply indebted to AnneMarie Hine (BMNH), Barbara Brown (AMNH), Barry Chernoff (FMNH), Carl Ferraris, David Catania (CAS), Edward O. Wiley (KU), Eldredge Bermingham (STRI), James Albert (UF), Hugo López (MLP), James Maclaine (BMNH), José Pezzi da Silva (MCP), José Lima Figueiredo (MZUSP), Kate Shaw (KU), Marcelo Loureiro (ZVC-P), Mary Anne Rogers (FMNH), Oscar Shibatta (MZUEL), Osvaldo Oyakawa (MZUSP), Paulo Buckup (MNRJ), Ricardo Rosa (UFPB), Richard Vari (USNM), Rigoberto Gonzales (STRI), Scott Schaefer (AMNH), Susan Jewett (USNM), Sven Kullander (NRM), Vinícius Abilhôa (MHNCI), William Saul (ANSP), and William Fink (UMMZ). David Maddison (University of Arizona) provided information on Coleopteran taxa. We are grateful to José Pezzi da Silva for curatorial help in MCP. Edson Pereira (MCP) photographed specimens. We owe special thanks to Carlos
Figueiredo (MNRJ), Carlos Lucena (MCP), Luiz Malabarba (MCP / UFRGS), Márcio Martins (FZB), Ricardo Rosa (UFPB), and a anonymous reviewer for comments and criticism on various versions of this manuscript. This study was developed during a doctoral program at the Pontifícia Universidade Católica do Rio Grande do Sul (PUCRS) and was supported by the Universidade do Tocantins (UNITINS), the Universidade Federal do Tocantins (UFT), and the Fundação Coordenação de Aperfeiçoamento de Pessoal de Nível Superior (CAPES, PICDT doctoral fellowship). RER is partially supported by CNPq through process 305344/87-0.

\section{Literature Cited}

Agassiz, L. 1834. Verzeichniss der in der PeträfaktenSammlung des vaterländischen Museums befindlichen versteinerten Fische, nach Prof. Agassiz Bestimmung. Prague. Verhandlungen Gessellschaft fur Vaterlandische Musuem Böhmen, 12:66-71.

Agassiz, L. 1853. Recent researches of Prof. Agassiz. [Extract from letter to J. D. Dana dated Cambridge, June 9th, 1853]. American Journal of Sciences and Arts (Ser. 2) 16(46):134-136.

Alvarez, J. 1952. Dicerophallini nueva tribu de Poeciliidae de Chiapas (Pisc., Cyprinodont.). Ciencia (Mexico City), 12:95-97.

Bailey, R. M. 1952. Proposed use of the plenary powers to designate a type species for the genus "Heterandria" Agassiz, 1853 (Class Osteichthyes, Order Cyprinodontida) in harmony with current usage. Bulletin of Zoological Nomenclature, 6:263-265.

Bleeker, P. 1860. Conspectus systematis Cyprinorum. Natuurkundig Tijdschrift Voor Nederlandsch-Indie, 20:421-441.

Bloch, M. E. \& J. G. Schneider. 1801. M. E. Blochii, Systema Ichthyologiae iconibus ex illustratum. Post obitum auctoris opus inchoatum absolvit, correxit, interpolavit Jo. Gottlob Schneider, Saxo. Berolini. Sumtibus Austoris Impressum et Bibliopolio Sanderiano Commissum. i-lx + 1-584p, pls. 1-110.

Bonaparte, C. L. 1831. Saggio di una distribuzione metodica degli animali vertebrati. 78 pp. Giornale Arcadico di Scienze Lettere ed Arti, 52:155-189.

Bonaparte, C. L. 1840. A new systematic arrangement of vertebrate animals. Transactions of the Linnean Society of London, 18(3):247-304.

Bonaparte, C. L. 1846. Catalogo metodico dei pesci europei. Atti di Scienze Italiana, Settima Adunanza, Napoli, 1-95.

Breden, F., M. B. Ptacek, M.Rashed, D. Taphorn \& C. A. A. Figueiredo. 1999. Molecular phylogeny of the live-bearing fish genus Poecilia (Cyprinodontiformes: Poeciliidae. Molecular Phylogenetics and Evolution, 12(2):95-104.

Costa, W. J. E. M. 1991. Description d'une nouvelle espèce du genre Pamphorichthys (Cyprinodontiformes: Poeciliidae) du bassin de l'Araguaia, Brésil. Revue Française d'Aquariologie, 18(2):39-42. 
Costa, W. J. E. M. 1996. Relationships, monophyly and three new species of the Neotropical miniature poeciliid fish genus Fluviphylax (Cyprinodontiformes, Cyprinodontoidei). Ichthyological Exploration of Freshwaters, 7(2):111-130.

Costa, W. J. E. M. 1998. Phylogeny and Classification of the Cyprinodontiformes (Euteleostei: Atherinomorpha): A Reappraisal, Pp. 537-560. In: Malabarba, L. R., R. E. Reis, R. P. Vari, Z. M. Lucena, \& C. A. S. Lucena (Eds.). Phylogeny and Classification of Neotropical Fishes. Porto Alegre, Edipucrs, 603p.

Cuvier, G. 1829. Le Règne Animal, distribué d'après son organisation, pour servir de base à l'histoire naturelle des animaux et d'introduction à l'anatomie comparée. Edition 2. Règne Animal, Volume 2: i-Xv + 1-406p.

Cuvier, G. \& A. Valenciennes. 1846. Histoire naturelle des poissons. Tome dix-huitième. Suite du livre dix-huitième. Cyprinoïdes. Livre dix-neuvième. Des Ésoces or Lucioïdes, 18: i-xix + 2p +1-505 + 2 p., pl. 520-553.

Dyer, B. S. \& B. Chernoff. 1996. Phylogenetic relationships among atheriniform fishes (Teleostei: Atherinomorpha). Zoological Journal of the Linnean Society, 117:1-69.

Eigenmann, C. H. 1903. The fresh-water fishes of western Cuba. Bulletin of the United States Fish Commission, 22 [1902]:211-236, pls. 19-21.

Eigenmann, C. H. 1907. The poeciliid fishes of Rio Grande do Sul and the La Plata Basin. Proceedings of the United States National Museum, 32(1532):425-433.

Eigenmann, C. H. 1909. Reports on the expedition to British Guyana of the Indiana University and the Carnegie $\mathrm{Mu}-$ seum, 1908. Report no. 1. Some new genera and species of fishes from British Guyana. Annals of the Carnegie Museum, 6(1):4-54.

Eigenmann, C. H. 1912 The freshwater fishes of British Guiana, including a study of the ecological grouping of species, and the relation of the fauna of the plateau to that of the lowlands. Memoirs of the Carnegie Museum, 5(1):i-xxii + 1-578p, pls. 1-103.

Farris. J. S. 1988. Hennig86 Reference, version 1.5.n.p.

Figueiredo, C. A. A. 1997. Revisão taxonômica e filogenia de Pamphorichthys Regan, 1913 (Cyprinodontiformes; Poeciliidae). Rio de Janeiro. UFRJ, Museu Nacional. xii, 139 p. Unpublished M.Sc. dissertation.

De Filippi, F. 1861. Note Zoologiche. IV. Lebistes nuovo genere di pesce della famiglia dei Ciprinodonti. Archivio di Zoologia, Anatomia ed Fisiologia di Genova, 1:69-70, $\mathrm{Pl} .4$.

Fowler, H. W. 1932. Notes on fresh water fishes from Central America. Proceedings of the Academy of Natural Sciences of Philadelphia, 84:379-385.

Fowler, H. W. 1949. Results of the two Carpenter African expeditions, 1946-1948. Part II - The fishes. Proceedings of the Academy of Natural Sciences of Philadelphia, 101:233-275.

Garman, S. 1895. The Cyprinodonts. Memoirs of the Museum of Comparative Zoology, 19:1-179.
Garman, S. 1896. Cross fertilization and sexual rights and lefts among vertebrates. American Naturalist, 30:232.

Ghedotti, M. J. 1998. Phylogeny and classification of the Anablepidae (Teleostei: Cyprinodontiformes). Pp. 561582. In: Malabarba, L. R., R. E. Reis, R. P. Vari, Z. M. Lucena, \& C. A. S. Lucena (Eds.). Phylogeny and Classification of Neotropical Fishes. Porto Alegre, Edipucrs, $603 p$.

Ghedotti, M. J. 2000. Phylogenetic analysis and taxonomy of the poeciloid fishes (Teleostei, Cyprinodontiformes). Zoological Journal of the Linnean Society, 130:1-53.

Ghedotti, M. J. \& S. H. Weitzman. 1995. Description of two new species of Jenynsia (Cyprinodontiformes: Anablepidae) from southern Brazil. Copeia, 1995:939-946.

Gill, T. N. 1857. On the fishes of New York. Annual Report of the Smithsonian Institution, 12:253-269.

Gill, T. N. 1865. Synopsis of the fishes of the Gulf of St. Lawrence and Bay of Fundy. Canadian Naturalist, 2:244-266.

Gill, T. N. 1872. Arrangement of the families of fishes or classes Pisces, Marsipobranchii, and Leptocardii. Smithsonian Miscellaneous Collections, 247:i-xlvi + $1-49 p$.

Gill, T. N. 1893. Families and Subfamilies of Fishes. Memoirs of the National Academy of Sciences, 6:127-138.

Gill, T. N. 1894. The nomenclature of the Poeciliidae or Cyprinodontidae. Proceedings of the United States National Museum, 17:115-116.

Gistel, J. 1848. Naturgeschichte des Thierreichs, für höhere Schulen. Stuttgart. Naturgeschichte Thierreichs: i-xvi + 216 p., $32 \mathrm{pl}$.

Gosline, W. A. 1949. The sensory canals of the head in some Cyprinodont fishes, with particular reference to the genus Fundulus. Occasional Papers of the Museum of Zoology, University of Michigan, 519:1-17.

Günther, A. 1866. Catalogue of fishes in the British Museum. Catalogue of the Physostomi, containing the families Salmonidae, Percopsidae, Galaxidae, Mormyridae, Gymnarchidae, Esocidae, Umbridae, Scombresocidae, Cyprinodontidae, in the collection of the British $\mathrm{Mu}-$ seum., 6:i-xv + 1-368p.

Hamilton, A. 2001. Phylogeny of Limia (Teleostei: Poeciliidae) based on NADH dehydrogenase subunit 2 sequences. Molecular Phylogeny Evolution, 19(2):277-289.

Heckel, J. J. 1848. Eine neue Gattung von Poecilien mit rochenartigem Anklammerungs - Organe. Sitzungsberichte der Akademie der Wissenschaften in Wien. Mathematisch-Naturwissenschaftliche Klasse, 1:289-303, pls. 8-9.

Henn, A. W. 1916. On various South American poeciliid fishes. Annals of the Carnegie Museum, 10(1-2):93-142.

Hennig, W. 1966. Phylogenetic Systematics. Urbana, Univ. Illinois Press. 263 p.

Hilgendorf, F. M. 1889. Über eine Fischsammlung von Haiti, welche 2 neue Arten, Poecilia (subg. n. Acropoecilia) tridens und Eleotris maltzani, enthält. Sitzungsberichte 
Der Gesellschaft Naturforschender Freunde Zu Berlin, 1889:51-55.

Howell Rivero, L. \& C. L. Hubbs 1936. Studies of the fishes of the order Cyprinodontes. XV. The characters and relationships of Furcipenis huberi and Alfaro cultratus. Occasional Papers of the Museum of Zoology, University of Michigan,, 339:1-11.

Howell Rivero, L. \& L. R. Rivas. 1944. Studies of the Cyprinodont fishes, two new genera of the tribe Girardinini, from Cuba. Torreia, 12:3-19, 2 pls.

Hubbs, C. L. 1924. Studies of the fishes of the order Cyprinodontes. Miscellaneous Publications of the Museum of Zoology, University of Michigan, 13:1-31, pls. 1-4.

Hubbs, C. L. 1926. Studies of the fishes of the order Cyprinodontes. VI. Miscellaneous Publications of the Museum of Zoology, University of Michigan, 16:1-86, pls. 1-4.

Hubbs, C. L. 1931. Studies of the fishes of the order Cyprinodontes. IX. A new and primitive genus of Poeciliidae from Central America. Occasional Papers of the Museum of Zoology, University of Michigan, 230:13 , pl. 1.

Hubbs, C. L. 1934. Studies of the fishes of the order Cyprinodontes. XIII. Quintana atrizona, a new poeciliid. Occasional Papers of the Museum of Zoology, University of Michigan, 301:1-8, pl. 1.

Hubbs, C. L. 1936. XVII. Fishes of the Yucatan Peninsula. Carnegie Institution of Washington Publication, 457:157287, pls. 1-15.

Hubbs, C. L. 1950. Studies of cyprinodont fishes. XX. A new subfamily from Guatemala, with ctenoid scales and a unilateral pectoral clasper. Miscellaneous Publications of the Museum of Zoology, University of Michigan, 78:128, pls. 1-4.

Ihering, R. von. 1930. Notas ecológicas referentes a peixes d'agua doce do Estado de S. Paulo e descripção de 4 espécies novas. Archivos do Instituto Biológico de São Paulo, 3:93-104.

International Commission on Zoological Nomenclature. 1999. International Code of Zoological Nomenclature. Fourth edition. International Trust for Zoological Nomenclature 1999. London. i-xxix + 306p.

Jenyns, L., 1842. Fish. In: Darwin, C. The Zoology of the Voyage of H.M.S. Beagle during the Years 1832-1836. Part 4. London, p. 115-117.

Kallman, K. D., R. B. Walter, D. C. Morizot \& S. Kazianis. 2004. Two new species of Xiphophorus (Poeciliidae) from the Isthmus of Tehuantepec, Oaxaca, Mexico, with a discussion of the distribution of the X. clemenciae clade. American Museum Novitates, 3441:1-34.

Kner, R. 1860. Über Belonesox belizanus, nov. gen. et spec., aus der Familie der Cyprinodonten. Sitzungsberichte der Akademie der Wissenschaften in Wien. MathematischNaturwissenschaftliche Klasse, 40(10):419-422.

Langer, W. F. 1913. Beiträge zur Morphologie der viviparen Cyprinodontiden. Morphologisches Jahrbuch, 47(12):193-307.
Lesueur, C-A. 1821. Description of a new genus, and of several new species of fresh water fish indigenous to the United States. Journal of the Academy of Natural Sciences of Philadelphia, 2(1):2-8, pls. 1-3.

Leviton, A. E. \& R. H. Gibbs, Jr. 1988. Standards in herpetology and ichthyology standard symbolic codes for institution resource collections in herpetology and ichthyology. Copeia, 1988:280-282.

Leviton, A. E., R. H. Gibbis, Jr., E. Heal \& C. E. Dawson, 1985. Standards in Herpetology and Ichthyology: Part I. Standard Symbolic for Institutional Resource Collections in Herpetology and Ichthyology. Copeia, 1985:802-832.

Lucinda, P. H. F. 2003. Family Poeciliidae. Pp. 555-581. In Reis, R.E., S.O. Kullander \& C. Ferraris Jr. (Eds.), Check List of the Freshwater Fishes, Porto Alegre, Edipucrs, 729p.

Lucinda, P. H. F. \& J. C. Garavello. 2001. Two new species of Cnesterodon Garman, 1895 (Cyprinodontiformes: Poeciliidae) from the upper rio Paraná drainage. Comunicações do Museu de Ciências e Tecnologia da PUCRS, Série Zoologia, 13(2):119-138.

Mateos, M., O. I. Sanjur \& R. C. Vrijenhoek. 2002. Historical biogeography of the livebearing fish genus Poeciliopsis (Poeciliidae: Cyprinodontiformes). Evolution, 56(5):972-984.

Marcus, J. M. \& A. R. McCune. 1999. Ontogeny and phylogeny in the northern swordtail clade of the genus Xiphophorus. Systematic Biology, 48(3):491-522.

Meek, S. E. 1904. The fresh-water fishes of Mexico north of the isthmus of Tehuantepec. Field Columbian Museum Zoological Series, 5:i-lxiii + 1-252p, pls. 1-17.

Meek, S. E. 1912. New species of fishes from Costa Rica. Field Museum of Natural History Publication, Zoological Series, 10(7):69-75.

Meyer, A. \& C. Lydeard. 1993. The evolution of copulatory organs, internal fertilization, placentas, and viviparity in killifishes (Cyprinodontiformes) as inferred from a DNA phylogeny of the tyrosine kinase gene X-scc. Proceedings of the Royal Society of London, Series B, 254:153-162.

Meyer, A., J. M. Morrissey \& M. Schartl. 1994. Recurrent origin of a sexually selected trait in Xiphophorus fishes inferred from molecular phylogeny. Nature, 386:539-542.

Meyer, M. K., 1993. Reinstatement of Micropoecilia Hubbs, 1926, with a Redescription of M. bifurca (Eigenmann, 1909) from Northeast South America (Teleostei, Cyprinodontiformes: Poeciliidae). Zoologische Abhandlungen Staatliches Museum für Tierkunde Dresden, 47(10):121-130.

Meyer, M. K. \& V. Etzel. 1996. Notes on the genus Priapichthys Regan (1913), sensu Radda (1985), with description of $P$. puetzi spec. nov. from the Atlantic slope of northern Panama (Teleostei: Cyprinodontiformes: Poeciliidae). Zoologische Abhandlungen Staatliches Museum für Tierkunde Dresden, 49(1):1-11. 
Meyer, M. K. \& V. Etzel. 1998. Notes on the genus Brachyrhaphis Regan 1913, with the description of a new species from Panama. Senckenbergiana Biolologica, 77(2):155-160.

Meyer, M. K. \& V. Etzel. 2001a. Additional notes on the genus Brachyrhaphis Regan, 1913, with description of a new species from Panama (Teleostei: Cyprinodontiformes: Poeciliidae). Zoologische Abhandlungen Staatliches Museum für Tierkunde Dresden, 51(4):33-39.

Meyer, M. K. \& V. Etzel. 2001b. Description of Cnesterodon raddai n. sp. from a swamp near Resistencia, Rio Paraná basin, Argentina (Teleostei: Cyprinodontiformes: Poeciliidae). Zoologische Abhandlungen Staatliches Museum für Tierkunde Dresden, 51(17):247-252.

Meyer, M. K. \& A. C. Radda. 2000. Notes on the subgenus Mollienesia LeSueur, 1821, with a description of a new species of Poecilia Bloch \& Schneider, 1801 (Cyprinodontiformes: Poeciliidae) from Venezuela. Annalen des Naturhistorischen Museum in Wien, 102(B):75-81.

Meyer, M. K. \& M. Schartl. 2002. Xiphophorus mayae, a new species of swordtail from Guatemala (Teleostei: Poeciliidae). Ichthyological Exploration of Freshwaters, 13(1):59-66.

Mojica C. L., A. Meyer \& G. W. Barlow. 1997. Phylogeny relationships of the species of the genus Brachyrhaphis (Poeciliidae) inferred from partial mitochondrial DNA sequences. Copeia, 1997:298-305.

Myers, G. S. 1935. An annotated list of the cyprinodont fishes of Hispaniola, with descriptions of two new species. Zoologica, 10(3):301-316.

Oliveros, O. B. 1983. Phallotorynus victoriae sp. nov. de la cuenca del rio Parana Medio, Argentina (Pisces, Poeciliidae). Revista de la Asociacion Ciencias Naturales del Litoral, 14(1):17-27.

Parenti, L. R. 1981. A phylogenetic and biogeographical analysis of Cyprinodontiform fishes (Teleostei, Atherinomorpha). Bulletin of the American Museum of Natural History, 168(4):341-557.

Parenti, L. R. \& M. Rauchenberger, 1989. Systematic overview of the poeciliins. Pp. 3-12. In: G. K. Meffe \& F. F. Snelson Jr. (Eds.). Ecology and Evolution Of Livebearing Fishes (Poeciliidae). Englewood Cliffs, Prentice Hall Inc., 453p.

de Pinna, M. C. C. 1991. Concepts and tests of homology in the cladistic paradigm. Cladistics, 7:367-394.

Poeser, F. N. 2002. Pseudolimia n. gen., a new monotypic genus for Limia heterandria Regan, 1913 (Teleostei: Poeciliidae). Beaufortia, 52(6):53-56.

Poeser, F. N. 2003. From the Amazon R. to the Amazon molly and back again. The evolution and systematics of the genus Poecilia Bloch and Schneider, 1801. (Ph. D. Thesis):122-129. [The "Thesis" was typeset and distributed, and regarded as a published work]

Poeser, F. N. \& I. J. H. Isbrücker. 2002. Zum wissenschaftlichen Namen des Guppy. Die Aquarien- und TerrarienZeitschrift, 55:47-49.
Poey, F. 1854. Los guajacones, pecesillos de agua dulce. In Poey, F. 1851-1854. Memorias sobre la historia natural de la Isla de Cuba, acompañadas de sumarios Latinos y extractos en Francés. La Habana. Mem. Hist. Nat. Cuba, 1:1-463, pls. 1-34.

Ptacek, M. \& Breden, F. 1998. Phylogenetic relationships among the mollies (Poeciliidae: Poecilia: Mollienesia group) based on Mitochondrial DNA Sequences. Journal of Fish Biology, 53(A):64-81.

Rafinesque, C. S. 1810. Indice d'ittiologia siciliana; ossia, catalogo metodico dei nomi latini, italiani, and siciliani dei pesci, che si rinvengono in Sicilia disposti secondo un metodo naturale e seguito de un appendice che contiene la descrizione de alcuni nuovi pesci sicilian. Messina. Indice d'Ittiologia Siciliano, 1-70, Pls. 1-2.

Ramos, T. 1997. Manual, TreeGardener, versão 2.2.

Rauchenberger, M. 1989. Systematics and biogeography of the genus Gambusia Cyprinodontiformes: Poeciliidae). American Museum Novitates, 2951:1-74.

Rauchenberger, M., K. D. Kallman \& D. C. Morizot. 1990. Monophyly and geography of the Río Panuco basin swordtails (genus Xiphophorus) with descriptions of four new species. American Museum Novitates, 2975:1-41.

Regan, C. T. 1908. A collection of freshwater fishes made by Mr. C. F. Underwood in Costa Rica. Annals and Magazine of Natural History, 2(11):455-464.

Regan, C. T. 1911. The osteology and classification of the teleostean fishes of the order Microcyprini. Annals and Magazine of Natural History, 7(40):320-327, pls 1-8.

Regan, C.T. 1912. A revision of the Poeciliid fishes of the genera Rivulus, Pterolebias, and Cynolebias. Annals and Magazine of Natural History (Ser 8), 10(59):494-508.

Regan, C. T. 1913. A revision of the Cyprinodont fishes of the subfamily Poeciliinae. Proceedings of the Zoological Society, 5:977-1019.

Regan, C. T. 1914. Descriptions of two new cyprinodont fishes from Mexico, presented to the British Museum by Herr A. Rachow. Annals and Magazine of Natural History, 14(79):65-67.

Rivas, L. R. 1958. The origin, evolution, dispersal, and geographical distribution of the Cuban poeciliid fishes of the tribe Girardinini. Proceedings of the American Philosophical Society, 102(3):281-320.

Rivas, L. R. 1963. Subgenera and species groups in the poeciliid fish genus Gambusia Poey. Copeia, 1963:331-347.

Rivas, L. R. 1980. Eight new species of poeciliid fishes of the genus Limia from Hispaniola. Northeast Gulf Science, 4(1):28-38.

Rivas, L. R. \& G. S. Myers. 1950. A new genus of poeciliid fishes from Hispaniola, with notes on genera allied to Poecilia and Mollienesia. Copeia, 1950:288-294.

Rodriguez, C. M. I. 1997. Phylogenetic analysis of the tribe Poeciliini (Cyprinodontiformes, Poeciliidae). Copeia, 1997:663-679.

Rosa, R. S. \& W. J. E. M. Costa. 1993. Systematic revision of the genus Cnesterodon (Cyprinodontiformes, Poeciliidae) 
with the description of two new species from Brazil. Copeia, 1993:696-708.

Rosen, D. E. 1952. A revision of the fishes of the subfamily Alfarinae in the family Poeciliidae. Zoologica, 37:151-156.

Rosen, D. E. 1959. Evolutionary significance of the axial and appendicular skeletons of viviparous cyprinodonts (Pisces). Anatomical Records, 132(3):496-497.

Rosen, D. E. 1964. The relationships and taxonomic position of the halfbeaks, killifishes, silversides, and their relatives. Bulletin of the American Museum of Natural History, 127(5):219-267.

Rosen, D. E. 1967. New Poeciliid fishes from Guatemala, with comments on the origin of some South and Central American forms. American Museum Novitates, 2303:1-15.

Rosen, D. E. 1979. Fishes from the uplands and intermontane basins from Guatemala: revisionary studies and comparative geography. Bulletin of the American Museum of Natural History, 162:269-375.

Rosen, D. E. \& R. M. Bailey 1959. Middle-American poeciliid fishes of the genera Carlhubbsia and Phallichthys with descriptions of two new species. Zoologica, 44(1):1-44, pls. 1-6.

Rosen, D. E. \& R. M. Bailey. 1963. The Poeciliid fishes (Cyprinodontiformes) their structure, zoogeography and systematics. Bulletin of the American Museum of Natural History, 126(1):1-176.

Rosen, D. E. \& M. Gordon. 1953. Functional anatomy and evolution of male genitalia in Poeciliid fishes. Zoologica, 38(1):1-47.
Rosen, D.E. \& K. D. Kallman. 1959. Development and Evolution of skeletal Deletion in a Family of viviparous fishes (cyprinodontiformes, Poeciliidae). Journal of the Florida Academy of sciences, 22(4):170-190.

Rosen, D. E. \& J. R. Mendelson. 1960. The sensory canals of head in Poeciliid fishes (Cyprinodontiformes), with reference to dentitional types. Copeia, 1960:203-210.

Swainson, W. 1838. The natural history and classification of fishes, amphibians, \& reptiles, or monocardian animals. A. Spottiswoode, London. Natural History \& Classification, Volume 1:i-vi +1-368p.

Steindachner, F. 1863. Beiträge zur Kenntniss der Sciaenoiden Brasiliens und der Cyprinodonten Mejicos. Sitzungsberichte der Akademie der Wissenschaften in Wien. Mathematisch-Naturwissenschaftliche Klasse, 48:162-185, pls. 1-4.

Taylor, W. R. \& G. C. Van Dyke. 1985. Revised procedures for staining and clearing small fishes and other vertebrates for bone and cartilage study. Cybium, 9:107-119.

Wagner, R. 1828. Beiträge zur Kenntniss der Gattung Lebias Cuvier und der verwandten Gattungen, nebst Beschreibung zweier neuen in Sardinien entdeckten Arten. Isis (Oken), 21(10):1050-1057, pl. 12.

Whitley, G. P. 1951. New fish names and records. Proceedings of the Royal Zoological Society of New South Wales, [volume for 1949-50]:61-68.

Received March 2004 Accepted January 2005 


\section{Appendix I}

Examined Material. Aplocheiloidei: Fundulidae: Fundulus heteroclitus, MCP 23910, 9/2*, USA. New York. Cyprinodontoidei: Cyprinodontidae: Cyprinodon macularius, MCP 23894, 9/2*, USA. Anablepidae: Jenynsia multidentata, Brazil. Rio Grande do Sul. MCP 11447, 76/1*, rio Camaquã, and adjacent ponds near Camaquã. - MCP 15473, 33/1*, lagoa de Tramandaí. Poeciliidae: Aplocheilichthyinae. Aplocheilichthys spilauchen.USNM 303703, 50+/4*, Cameroon, Lower Ndian system, S of Korup to seacoast; mangrove channels around Isangele village. Fluviphylax pygmaeus. MZUSP 29373, 60/4*, Brazil. Rondônia, rio Machado, lago de Paracaúba. Procatopus gracilis. USNM 303352, 15/ 4*, Cameroon, upper Ndian river bordering Korup; stream junction with Ndian. Poeciliinae. Alfaro huberi, UMMZ 190567, 30/4*, Guatemala. Zacapa, río Pasabien, $2 \mathrm{~km}$ above NNW $c a$. hwy 9, $10 \mathrm{~km}$ WSW of río Hondo. Belonesox belizanus UF 116114, 7/2*, USA, Florida. UF 34775, 30/2*, United States. Florida, Dade Everglades. Brachyrhaphis rhabdophora, ANSP 144181, 26/1* and ANSP 144173, 23/1*, Costa Rica, Puntarenas, Peninsula de Osa, Corcovado National Park. Carlhubssia kidderi. UMMZ 184619, 30/4*, Mexico. Tabasco, río Chilapa, ca. 6 miles by boat NW of Ciudad Pemex landing. Cnesterodon brevirostratus. MCP 13950, 27/4*, Brazil. Rio Grande do Sul. Bom Jesus, rio Manuel Leão. MCP 19785, 324/6*, São Francisco de Paula, arroio da Serraria in road Potreiro Velho - Pró-Mata. Cnesterodon carnegiei. MHNCI 7609, 9/1*, Brazil. Paraná. Almirante Tamandaré, rio Passaúna. USNM 304991, $12 / 2^{*}$, stream in fazenda Lara Maria, tributary of ribeirão Amola-Faca, near Balsa Nova. Cnesterodon decemmaculatus. MCP 10397, 47/ 4*, Uruguay, Sierra Mahoma. MCP 11404, 30/4*, Quaraí, arroio Garupá, between Quaraí and Alegrete. Cnesterodon hypselurus. MCP 12593, 31/ 6*, Brazil. Paraná. Jaguariaíva, rio Cilada, bridge of road BR 151, rio Paranapanema drainage. - MCP 22744, 9/2*, paratopotypes. Cnesterodon omorgmatos. MCP 22742, 21/4*, Brazil. Paraná. Pinhão, rio das Torres. Cnesterodon raddai. UMMZ 207503, 12/1*, Paraguay. Misiones, small stream at bridge on dirt road to Ayolas ( $c a .51 .2 \mathrm{~km} \mathrm{~S}$ of San Patricio), $c a$. $2 \mathrm{~km}$ ENE of Ayolas; río Paraná drainage. 2722'12”S 56 $43^{\circ} 12^{\prime \prime} \mathrm{W}$. Neembucu. UMMZ 207748, 30/2* of 102, Paraguay. Misiones, small pool on S side of dirt road between San Ignacio and Pilar, $c a .114 \mathrm{~km}$ WNW of San Ignacio ( $c a .8 \mathrm{~km}$ WNW of San Juan) 26 40'24"S 5755'12”W. Cnesterodon septentrionalis. MZUSP 41370, 25/1*, paratypes, Brazil. Mato Grosso. Alto Araguaia, swamp near córrego do Rancho fountainhead. MZUSP 69687, 21/4* of 42, Alto Araguaia, ribeirão do Sapo, $464.04 \mathrm{~km}$ from ferrovia Ferronorte. Cnesterodon n. sp. A, MZUSP 54978, 12/2*, Brazil. São Paulo. Apiaí, creek on headwaters of rio Iporanga, inside Mineradora Oxical, 2424'42"S 4839'25" W. Gambusia holbrooki. MZUSP 46100, 7/2*, USA, North Carolina, Lumber river at US Route 74 crossing near Boardman, Robeson-Columbus counties (border). Girardinus uninotatus, AMNH 96301, 30/4*, Cuba. Pinar Del Río, río Taco Taco. Heterandria jonesii, UMMZ 210999, 30/4*, Mexico. Veracruz, spring on Rancho Santa Anita, $6 \mathrm{~km}$ NNW of Potrero Viejo. Limia vittata, AMNH 96567, 30/4*, Cuba. Sancti Spiritus, Cuyuji, $17 \mathrm{~km}$ Sof Iznaga. Micropoecilia branneri, MCP 22040, 5/1*, Brazil Pará. Castanhal, igarapé Apeú, on road Belém - Brasília. Micropoecilia $s p$. , MCP 22055, 209/4*, Brazil. Maranhão. Peritoró, rio Peritoró, Neoheterandria tridentiger. STRI 2335, 10/4*, Panamá. río Anton, stream through thermal. STRI 2351, 10, río Santa Maria, Quebrada on the Divisa. Pamphorichthys hollandi, MCP 16851, 104/4*, Brazil. Bahia. Guanambi, rio da Olaria, $30 \mathrm{~km}$ E of Malhada, on road to Guanambi. Pamphorichthys scalpridens, MCP 15386, 300/6*, Brazil. Pará. Itaituba, braço morto of rio Tapajós, at bairro da Piracuna, Itaituba. Phallichthys fairweatheri, UMMZ 196466, 30/4*, Mexico. Quintana, laguna Caobas, $2 \mathrm{~km} \mathrm{~S}$ of Hwy 186, from which turnoff is $3 \mathrm{~km}$ and of road to San Antonio. Phalloceros caudimaculatus. MCP 20158, 16/4*, Sapiranga, arroio Feitoria. Phalloceros n. sp. A. MCP 19831, 20/4*, Brazil. Rio Grande do Sul, Mariana Pimentel, stream affluent to arroio dos Ratos, at Horto Florestal Mariana. Phalloceros n. sp. B. MCP 30548, 14/4*, Brazil, Bahia, Prado, fourth stream flowing E at $26 \mathrm{~km}$ from Prado on road from Prado to Cumuruxatiba. Phalloceros n. sp. C. UFPB 2214, 14/1* of 37, Brazil. Bahia. Porto Seguro, unnamed stream affluent to rio Camurigi, rio João de Tiba drainage, Estação Ecológica Pau Brazil, 15 km NW from Porto Seguro. UFPB 2748, 22/2* of 68, Brazil. Bahia. Porto Seguro, unnamed stream, rio João de Tiba drainage, Estação Ecológica Pau Brazil, $15 \mathrm{~km}$ NW from Porto Seguro. Phalloceros n. sp. D. USNM 330339, 5/ $2^{*}$, Brazil. Goiás, Aruanã, rio Araguaia drainage. Phalloceros n. sp. E. MCP 20585, 26/2*, Brazil, Rio de Janeiro, Cachoeiras de Macacu, rio Macacu, ca. $1.5 \mathrm{~km} \mathrm{SE}$ of Macacu, near road RJ 116. 22²9'9'S 42³9'34'W. Phalloceros n. sp. F. MCP 30512, 6/4*, Brazil, Rio de Janeiro, Sapucaia, rio São Francisco, tributary to rio Paquequer fazenda
São Francisco de Paula. Phalloceros n. sp. G. MCP 30509, 6/2*; Brazil. Rio de Janeiro, rio Parati-Mirim, near km 202 of BR 101, upstream Vila do Patrimônio. Phalloceros n. sp. H. MCP 12603, 87/4*, Brazil, Rio de Janeiro, Parati, rio São Roque nearby road BR 101. Phalloceros n. sp. I. MCP 13735, 11/4*, Brazil, Santa Catarina, rio Lindo, affluent to rio Cubatão, ca. $1 \mathrm{~km}$ from Trevo on road Pirabeiraba - Campo Alegre (SC301), Pirabeiraba. Phalloceros n. sp. J. MCP 29270, 256/6*, Brazil, Rio Grande do Sul, Itati, creek ca. $200 \mathrm{~m}$ from arroio do Padre. Phalloceros n. sp. L. MCP 20579, 117/4*, creek on Iporanga exit to Apiaí, Apiaí, São Paulo, Brazil. Phalloceros n. sp. M. MCP 12549, 4/2*, Brazil, Paraná, Paranaguá, rio Jacareí at km 18 on road BR 277. Phalloceros n. sp. N. MCP 25561, 3/1*, Brazil, Paraná, Antonina, flooded areas on margins of the PR 340. MCP 27005, 2/1*, Antonina, rio Dois de Fevereiro. Phalloceros n. sp. O. MCP12197, 87/6*, Brazil, São Paulo, Juquiá, creek on road BR 116, near Juquiá (affluent to rio Juquiá). Phalloceros n. sp. $P$. MCP 30511, 6/2*, Brazil, Minas Gerais, Lagoa Santa, córrego do Jaque, tributary of the left margin of the rio das Velhas. Phalloceros n. sp. Q. MHNCI 6151, 8/2*, Brazil, Paraná, Paranaguá, creek at Praia do Forte, Ilha do Mel. MHNCI 6262, 4/2*, Brazil, Paraná, Pontal do Paraná, Balneário de Shangri-lá. Phalloceros n. sp. R. MZUSP 35422, 7/2*, Brazil, Santa, Catarina, Itapoá. Phalloceros n. sp. S. MCP 30510, 6/4*, Brazil, Rio de Janeiro, Parati, córrego da Toca do Boi, near Condomínio Laranjeiras. Phalloceros n. sp. T. MZUSP 43467, 26/3*, Brazil. Paraná. Creek near beach, Guaratuba. USNM 297945, 13/2*, Brazil. Paraná. rio da Praia, near Guaratuba. Phalloceros n. sp. U. MCP 30023, 90/5*, Brazil, Espírito Santo, Itarana, córrego Limoeiro, at Praça Oito. UMMZ 215307, 31/4*, Brazil, Espírito Santo, Santa Tereza, córrego at Valsugana Velha. Phalloceros n. sp. V. MCP 30508, 6/4*, Brazil, Rio de Janeiro, Sapucaia, rio São Francisco, tributary to rio Paquequer, fazenda São Francisco de Paula. MCP 20569, 165/10*, Brazil, Rio de Janeiro, Teresópolis, rio Paquequer, near bridge on $\mathrm{km} 86$ on road BR 116, upstream Represa Guinle. Phalloptychus iheringii. MCP 11054, 107/8*, Brazil. Santa Catarina. Tubarão, rio Tubarão and lateral channels near Campo Verde. MCP 26060, 2/1*, Brazil. Rio Grande do Sul. Rio Grande, Ilha dos Marinheiros, Porto Rei. MCP 26061, 3/1*, Rio Grande. MCP 26062, 2/ $1^{*}$, Brazil. Rio Grande do Sul. Rio Grande, Ilha dos Marinheiros, Ponta da Marambaia. Phalloptychus januarius. MCP 8493, 65/4*, Brazil. Rio de Janeiro, lagoa de Jacarepaguá.. MNHCI 6174, 15/4*, Brazil. Paraná, Guaraqueçaba, Ilha de Superagui. MNHCI 6183, 27/4*, Brazil. Paraná. Paranaguá, Ilha do Mel, Praia de Brasília. Phallotorynus n. sp. A. NRM $42823,8 / 2 *$, arroyo Cambay where crossing about $16 \mathrm{~km}$ on road Caaguazú-Yhú. Phallotorynus fasciolatus. MZUSP 41373, 16/2*, Brazil. São Paulo. Campo Grande, Paranapiacaba. Phallotorynus jucundus. MCP 25415, 5/2*, Brazil. São Paulo. São Simão, rio Tamanduá headwaters, affluent to rio Pardo. UFPB 2161, 21/1* of 50, Brazil. São Paulo. São Simão, rio Tamanduá headwaters, affluent to rio Pardo. Phallotorynus n. sp. C, MZUSP 69189, 7/1*, Brazil. Mato Grosso, Tacuru, road to Paranhos on creek at fazenda Sossego, tributary to rio Puitá, affluent to rio Iguatemi. Phallotorynus n. sp. B. UFPB 2165, 4/2*, Paraguay. San Pedro, río Aguaray on dirt highway, $2.1 \mathrm{~km} \mathrm{~N}$ of road $\mathrm{E}$ to Capitan Bado, affluent to rio JejuiGuazu. UMMZ 240156, 80/9*, Paraguay. San Pedro, río Aguaray and associated run-off ditch at bridge on dirt highway (route 3), $2.1 \mathrm{~km} \mathrm{~N}$ of junction with road E to Capitan Bado. Phallotorynus victoriae. NRM 42907, 73/4*, Paraguay. Alto Paraná. río Acaray, km 12. "Poecilia" reticulata. MCP 20592, 103/6*, Brazil. Rio de Janeiro, rio Macacu, ca. $1.5 \mathrm{~km}$ SE of Cachoeiras de Macacu. Rio de Janeiro. Poecilia vivipara, MCP 18118, 39/6*, Brazil. Bahia. Helvécia. córrego Pau Alto (affluent to rio Pau Alto), on road BR-418, ca. $58 \mathrm{~km}$ E of Nanuque. Poeciliopsis gracilis, MCP 23916, 20/2*, Mexico, Chiapas. Priapella compressa, UMMZ 210816, 20/4*, Mexico. Chiapas, río Misala just below bridge on hwy to Agua Azul, at Ruiz Cortinez. Priapichthys annectens, ANSP 163139, 43/4*, Costa Rica. Limon, creek crossing new oil company road from Bri-Bri to Suretka $4 \mathrm{~km} \mathrm{~W}$ of Bri-Bri. Pseudopoecilia fria, USNM $338706,10 / 2^{*}$, Ecuador. West tributary to río Baba (Guayas Drainage), $300 \mathrm{~m} \mathrm{~S}$ of Al Balnearia road and $1 \mathrm{~km} \mathrm{~S}$ of San Andres. Quintana atrizona, AMNH 96396, 30/4*, Cuba. Isla de la Juventud, $16 \mathrm{~km}$ SE of la $\mathrm{Fe}$, Canal de la Isabela, La Reforma District. Scolichthys greenwayi, AMNH 32887, 30/4*, Guatemala. Alta Verapaz, source and mouth of río Candelaria Yalicar. Tomeurus gracilis. MNRJ 15180, 20/2* of 41, Brazil. Amapá. Mazagão. Queimada near Mazagão. MZUSP 26512, 20/4* of 30, igarapé Inó, Furo de Panaquera. AMNH 72910, 26/5* of 31, Guyana. Cuyuni-Mazaruni. Kartabo point, confluence Mazaruni and Cuyuni Rivers. Xenodexia ctenolepis, AMNH 32137, 30/4*, Guatemala. Huehuetenango, just above Todos Santos, río Ixcan at channel on E side of island. Xenophallus umbratilis, ANSP 169120, 30/4*, Costa Rica. Guanacaste, North shore of lago Arenal about $22 \mathrm{~km}$ E of Nuevo Arenal. Xiphophorus sp., MNRJ 17932, 33/4*, Brazil. Rio de Janeiro. Rio Claro, ribeirão das Lages or rio Pires, near fazenda Lorena. 
Appendix II. Character state data matrix of 145 characters for 65 poeciliine taxa and 6 outgroup taxa. All transformation series were considered unordered. Question marks indicate that character state could not be checked due to lack of available specimens or structures. Dashes indicate both inapplicable codings and polymorphisms.

\begin{tabular}{|c|c|c|c|c|c|c|c|c|}
\hline & $\begin{array}{l}0000000000 \\
0000000000 \\
0123456789\end{array}$ & $\begin{array}{l}0000000000 \\
1111111111 \\
0123456789 \\
\end{array}$ & $\begin{array}{l}0000000000 \\
2222222222 \\
0123456789 \\
\end{array}$ & $\begin{array}{l}0000000000 \\
3333333333 \\
0123456789 \\
\end{array}$ & $\begin{array}{l}0000000000 \\
4444444444 \\
0123456789 \\
\end{array}$ & $\begin{array}{l}0000000000 \\
5555555555 \\
0123456789 \\
\end{array}$ & $\begin{array}{l}0000000000 \\
6666666666 \\
0123456789 \\
\end{array}$ & $\begin{array}{l}0000000000 \\
7777777777 \\
0123456789 \\
\end{array}$ \\
\hline Phalloceros n. sp. B & 0013200152 & 1230010221 & -100101111 & $? 111020100$ & 0100101211 & 0041020002 & $111-0111$ & 002002000 \\
\hline Phalloceros n. sp. C & 0013200152 & 1230010001 & $01001 ? 1111$ & ?111010000 & 0100101211 & 0042320002 & 1111220111 & 0020020001 \\
\hline Phalloceros n. sp. D & 0013200152 & 1230010000 & $11001 ? 1011$ & $1111010 ? 00$ & 0100101211 & 0041020002 & 1111210111 & 0020120001 \\
\hline Phalloceros n. sp. G & 0013200152 & 1230010000 & $01001 ? 1111$ & 1111020000 & 0100101211 & 0041020002 & 1111220111 & 002002000 \\
\hline Phalloceros n. sp. F & 0013200152 & 1230010000 & 0100101111 & 1111020100 & 0100101211 & 0041020002 & 1111220111 & 002012000 \\
\hline Phalloceros n. sp. E & 0013200152 & 1230010000 & 0100101111 & 0111020100 & 0100101211 & 0041020002 & 1111220111 & 002002000 \\
\hline Phalloceros n. sp. J & 0013200152 & 1230010220 & 0100101111 & 0111010100 & 0100101211 & 0021020002 & $11-4220111$ & 002012000 \\
\hline Phalloceros n. sp. I & 0013200152 & 1230010220 & $01001 ? 1111$ & 0111020100 & 0100101211 & 0041020102 & 1111220111 & 002002000 \\
\hline Phalloceros n. sp. $P$ & 0013200152 & 1230010000 & -100101111 & 0111020100 & 0100101211 & 0041020002 & 1114210111 & 002002000 \\
\hline Phalloceros n. sp. H & 0013200152 & 1230010220 & $01001 ? 1111$ & 1111020100 & 0100101211 & 0041020002 & $11-12-0111$ & 011012000 \\
\hline Phalloceros n. sp. $O$ & 0013200152 & 1230010220 & 0100101111 & 0111020100 & 0100101211 & 0041020002 & $117-2-0111$ & 002002000 \\
\hline Phalloceros n. sp. $R$ & 0013200152 & 1230010220 & 0100101111 & $01110 ? 0 ? 00$ & $0000-01213$ & $0041020 ? 0 ?$ & 11712201?? & ???0????? \\
\hline Phalloceros n. sp. M & 0013200152 & 1230010000 & 0100101111 & 0111020100 & 010010???? & 00???????? & 1??4-101?? & ???0????? \\
\hline Phalloceros n. sp. $Q$ & 0013200152 & 1230010220 & 0100101111 & 0111020100 & 0100101211 & 0041020002 & 1111210111 & 002012000 \\
\hline Phalloceros n. sp. L & 0013200152 & 1230010220 & 0100101111 & 0111020100 & 01001012- & 0041020002 & $11112-0111$ & 002002000 \\
\hline Phalloceros n. sp. N & $00 ? 3200152$ & 1230010??? & 0100??1?1? & ?111020100 & 010010???? & 0????????? & $1 ? ? 12-01 ? ?$ & \\
\hline Phalloceros n. sp. $T$ & 0013200152 & 1230010220 & 0100101111 & 0111021100 & $0 ? ? 0101211$ & 0041020002 & 1111220111 & 0020020001 \\
\hline Phalloceros n. sp. S & 0013200152 & 1230010220 & 0100101111 & & 0100101211 & 0041020002 & & 0020020001 \\
\hline Phalloceros n. sp. U & 0013200152 & 1230010000 & 0100101111 & 1111021100 & 0100101211 & 0041020002 & $117-220111$ & 002002000 \\
\hline Phalloceros n. sp. V & 0013200152 & 1230010221 & 0100101111 & 0111020100 & 0100101211 & 0041020002 & $1111-20111$ & 0020020001 \\
\hline Phalloceros n. sp. A & 0013200152 & 1230010000 & 01001-1111 & & & 0041020002 & -20110 & \\
\hline Phalloceros caudimaculatus & 0013200152 & 1230010000 & 0100101111 & 0111020100 & 0100101211 & 0041020002 & $111-220111$ & 0020020001 \\
\hline Phalloptychus eigenmanni & ?????00102 & 1????????? & ?1????????? & ??1???????? & ????01???? & ??????????? & ????-1?1?? & ?????????? \\
\hline Phalloptychus januarius & 0023000102 & 1221010010 & 0100101111 & $0-12012310$ & 13011 & 0013230011 & 1100112130 & 0110100003 \\
\hline Phalloptychus iheringii & 0023000102 & 1221010010 & 0100101111 & $0-12012310$ & & 230011 & & 0110100003 \\
\hline Phallotorynus fasciolatus & $00 ? 3000022$ & 1030010000 & ?100??1?1? & & & 0001020002 & & \\
\hline Phallotorynus jucundus & 0023200022 & 1230010000 & 1100101111 & 0111010000 & 0000101211 & 0001020002 & 1111011111 & 1020022021 \\
\hline Phallotorynus victoriae & 0023200022 & 1230010000 & & & & 0001020002 & & 1020021021 \\
\hline us n. sp. $A$ & 0023200022 & 1230010000 & & & 000010 & 0001020002 & & 2021 \\
\hline Phallotorynus n. sp. B & 0023200022 & 1230010000 & 0100101111 & 10000 & 0000101 & 0001020002 & & 1220122022 \\
\hline Cnesterodon decemmaculatus & 0023000112 & 1221010000 & & $011-030201$ & 021010-300 & $003 \quad 1102$ & $110-10102$ & 0020200112 \\
\hline Cnesterodon carnegiei & 0023000112 & 1221010000 & 1100101011 & 0112030201 & 0210100300 & $003-1102$ & 1010210102 & 0020200112 \\
\hline Cnesterodon brevirostratus & 0023000112 & & & & & $003-1102$ & & 0020200112 \\
\hline Cnesterodon septentrionalis & 0023000112 & 1021010000 & & & & $003-1-02$ & & 00112 \\
\hline Cnesterodon omorgmatos & 0023000112 & 1221010000 & & & & $003-1102$ & & 0020200112 \\
\hline Cnesterodon hypselurus & 0023000112 & 1021010000 & & 0111030201 & & $003-1102$ & $11-21$ & 0020200112 \\
\hline Cnesterodon n. sp. B & 0023000112 & 1251010000 & 00101111 & & & & & 0020000112 \\
\hline Ion n. sp. $A$ & 0023 & 102 & & & & $003-1102$ & & 0120000112 \\
\hline Cnesterodon raddai & 0023000112 & 1221010000 & b101111 & ???? & 0210 & $00 ?-1 ? 00$ & $? 0 ? ? ?$ & ???0?0??? \\
\hline & & & & & & 01023-0000 & & 1020200104 \\
\hline Micropoecilia sp & 0023000001 & 1221010000 & & & & $23-0000$ & & 1000000101 \\
\hline Micropoecilia branneri & 0023000001 & & 0100101111 & & & & & 1020200101 \\
\hline Pamphorichthys hollandi & & & & & & & & \\
\hline Pamphorichthys scalpridens & 0023100112 & 1221010000 & 1100101111 & 0010110110 & $00000002-2$ & $11032-0000$ & 114233 & 0020000104 \\
\hline & & & & & & & & \\
\hline & 0011020000 & 1221011 & & & 000002- & 00010-0000 & $1142-10120$ & 0110000101 \\
\hline Xenodexia ctenolepis & 0022000000 & $6-21011000$ & 2100101111 & 0010100100 & & 0000110000 & 1162020020 & 0000000103 \\
\hline & & 1221011 & & & & & & 0020000011 \\
\hline Poeciliopsis gracilis & 0010000001 & 1221011010 & 0100101111 & & 0100001211 & 0012020001 & 0212120 & 1110100003 \\
\hline & & & & & & & & 1120020011 \\
\hline Ilus umbratilis & & & & & & 0001 & 2120 & 111 \\
\hline Quintana atrizona & 0010000001 & 1231010000 & 0100101111 & & & 0000110001 & 016 & 0020000031 \\
\hline Phallichthys fairweatheri & & & & & & & & 1110000013 \\
\hline Carlhubbsia kidderi & 0010021001 & 1221011000 & 0100101111 & 0010010000 & 0000001211 & 0001110001 & 1127021121 & 1020000001 \\
\hline & & & & & & & & \\
\hline hys annectens & 1011001 & & 0010100001 & 0010010100 & 0000001211 & 0000110000 & $000-010120$ & 1110100011 \\
\hline Neohetrandria tridentiger & 0001000002 & 1010000000 & 0011100001 & 0010021000 & 0100003211 & 0001020001 & 0024-10120 & 1110000011 \\
\hline & & & & & & & & \\
\hline Scolichthys greenwayi & 0001000112 & 1010000000 & 1011100101 & 0110040010 & 0000000211 & 0001020001 & 1011110111 & 0020000011 \\
\hline & & & & & & & & \\
\hline$x$ belizanus & & & & & & 00010100 & 1071110121 & 0111110024 \\
\hline Brachyrhaphis rhabdophora & 0001011001 & 0100100000 & 0010000001 & 0010000000 & 0000001211 & 0000400000 & 0063110121 & 002000002 \\
\hline & & & & & & & & \\
\hline Tomeurus gracilis & 0013000142 & 1000000000 & $001-010001$ & 0013031100 & 0210200100 & $0-0000$ & 0036420100 & $0-10200100$ \\
\hline Alfaro huberi & & & & & & $00-0000$ & & \\
\hline Fluviphylax pygmaeus & & & $10-0100100$ & & & $00-0000$ & $0055-400-0$ & 0000000000 \\
\hline Procatopus gracilis & 1123011000 & 2000000000 & 0000100000 & 0010040100 & 0000000000 & $00-0000$ & $00-0000-0$ & 0000000100 \\
\hline Aplocheilichthys spilauchen & & & & & & $00-0000$ & $00-02000-0$ & \\
\hline Jenynsia unitaenia & 0000022000 & 0000000000 & 0100000001 & 0000000000 & 0000000000 & $00-0000$ & $004 ? 11-0-0$ & 000000000 \\
\hline Cyprinodon macularius & 0003022003 & 0010000110 & 1100100101 & 0000000100 & 0000001000 & $00-0000$ & $00820000-0$ & 000000000 \\
\hline & 0000022000 & 0010000110 & 0000100000 & 0100000000 & $0000000-00$ & $00-0000$ & $00000100-0$ & 000000000 \\
\hline
\end{tabular}


Appendix II. Cont.

\begin{tabular}{|c|c|c|c|c|c|c|c|}
\hline \multirow{3}{*}{ TAXA } & 0000000000 & 0000000000 & 1111111111 & 1111111111 & 1111111111 & 1111111111 & 1111 \\
\hline & 8888888888 & 9999999999 & 0000000000 & 1111111111 & 2222222222 & 3333333333 & 4444 \\
\hline & 0123456789 & 0123456789 & 0123456789 & 0123456789 & 0123456789 & 0123456789 & 0123 \\
\hline Phalloceros n. sp. $B$ & 0010041000 & 1111000000 & $000-0-00$ & 1300101010 & 0000001200 & $0-? 0100110$ & $010 ?$ \\
\hline Phalloceros n. sp. C & 0010001000 & 1111000000 & $000-0-00$ & 1300101010 & 0000001200 & 0100100110 & 0101 \\
\hline Phalloceros n. sp. $D$ & 0010001000 & 1111000000 & $000-0-00$ & 1000101010 & 0000001200 & 0-?0100110 & $010 ?$ \\
\hline Phalloceros n. sp. G & 0010041000 & 1111101010 & $000-0-00$ & 1300101010 & 0000001100 & 0310000110 & 0121 \\
\hline Phalloceros n. sp. F & 0010041000 & 1111101010 & $000-0-00$ & 1300101010 & 0000001100 & 0100500110 & 0121 \\
\hline Phalloceros n. sp. E & 0010001000 & 1111101010 & $000-0-00$ & 1300101010 & 0000001100 & 0100200110 & 0121 \\
\hline Phalloceros n. sp. J & 0010001000 & $1111-120-0$ & $000-0-00$ & 1300101010 & 0000001100 & 0100200110 & 0112 \\
\hline Phalloceros n. sp. I & 0010001000 & 1111200110 & $000-0-00$ & 1300101010 & 0000001200 & 0110200110 & 0111 \\
\hline Phalloceros n. sp. P & $00100 ? 1000$ & 1111211020 & $000-0-00$ & 1300101010 & 0000001200 & 0100300110 & 0111 \\
\hline Phalloceros n. sp. $H$ & 0010041000 & 1111211020 & $000-0-00$ & 1300101010 & 0000001200 & 0100400110 & 0111 \\
\hline Phalloceros n. sp. O & 0010041000 & 1111211020 & $000-0-00$ & 1300101010 & 0000001200 & $01-0200110$ & 0111 \\
\hline Phalloceros n. sp. $R$ & $0 ? 10041000$ & 1111200110 & $000-0-00$ & 1300101010 & 0000001200 & $01 ? 0200110$ & 0111 \\
\hline Phalloceros n. sp. M & $? ? 10041000$ & 1111201020 & $000-0-00$ & 1300101010 & 0000001200 & 0100200110 & 0111 \\
\hline Phalloceros n. sp. $Q$ & 0010041000 & 1111211020 & $000-0-00$ & 1300101010 & 0000001200 & 0100200110 & 0111 \\
\hline Phalloceros n. sp. L & 0010041000 & 1111211020 & $000-0-00$ & 1300101010 & 0000001100 & 0100200110 & 0111 \\
\hline Phalloceros n. sp. $N$ & $? ? 10041000$ & 1111200110 & $000-0-00$ & 1300101010 & 0000001200 & $01 ? 0200110$ & $011 ?$ \\
\hline Phalloceros n. sp. T & 0010001000 & $? 111200010$ & $000-0-00$ & 1300101010 & 0000001200 & 0100200110 & 0101 \\
\hline Phalloceros n. sp. S & 0010001000 & 1111200010 & $000-0-00$ & 1300101010 & 0000001200 & 0100200110 & 0101 \\
\hline Phalloceros n. sp. U & 0010001000 & 1111200010 & $000-0-00$ & 1300101010 & 0000001200 & 0100200110 & 0101 \\
\hline Phalloceros n. sp. V & 0010041000 & 1111200010 & $000-0-00$ & 1300101010 & 0000001100 & 0-00-00110 & 0101 \\
\hline Phalloceros n. sp. A & 0010001000 & 1111000000 & $000-0-00$ & 1300101010 & 0000001100 & $01-0000110$ & 0101 \\
\hline Phalloceros caudimaculatus & $00100-1000$ & 1111000000 & $000-0-00$ & 1300101010 & 0000001100 & 0100200110 & 0101 \\
\hline Phalloptychus eigenmanni & ??1???110? & ????——— & ????????0? & ????1?1??0 & 0??0?0???? & ?201000??? & $010 ?$ \\
\hline Phalloptychus januarius & 1010041100 & $0000-0$ & $00-0-00$ & 0000101100 & 0000002201 & 0211000010 & 0100 \\
\hline Phalloptychus iheringii & 1010031100 & $0000-0$ & $00-0-00$ & 0000101100 & 0000002201 & 0211000010 & 0100 \\
\hline Phallotorynus fasciolatus & 0010031001 & $1110-0$ & 10?-????00 & $? ? 00102000$ & 0000001110 & 0100001110 & 1101 \\
\hline Phallotorynus jucundus & 0010041001 & $1110-0$ & $101-110100$ & 2100102000 & 0000001110 & 0100032110 & 2101 \\
\hline Phallotorynus victoriae & 0010031001 & $1110-0$ & $101-100000$ & 2100102000 & 0000001110 & 0100011110 & 1101 \\
\hline Phallotorynus n. sp. A & 0010041001 & $1110-0$ & $101-201200$ & 2200102000 & 0000001110 & 1100021110 & 1101 \\
\hline Phallotorynus n. sp. $B$ & 0010041001 & $1110-0$ & $101-100000$ & 2200102000 & 0000001110 & 1100011110 & 1101 \\
\hline Cnesterodon decemmaculatus & 0010041000 & $1110-0$ & $01000-00$ & 0000102000 & $001010-210$ & 0010000001 & 0100 \\
\hline Cnesterodon carnegiei & 0010041000 & $1110-0$ & $01010-00$ & 1100102000 & 0010101210 & 0010000001 & 0100 \\
\hline Cnesterodon brevirostratus & 0010041000 & $1110-0$ & $010-0-00$ & 1100102000 & 0010101210 & 0010000001 & 0100 \\
\hline Cnesterodon septentrionalis & 0010041000 & $1110-0$ & $01010-00$ & 1100102000 & 0010101210 & 0000000001 & 0100 \\
\hline Cnesterodon omorgmatos & 0010041000 & $1110-0$ & $01010-00$ & 1100102000 & 0010101210 & 0010000001 & 0100 \\
\hline Cnesterodon hypselurus & 0010041000 & $1110-0$ & $01010-00$ & $110010-000$ & 0010101210 & 0010000001 & 0100 \\
\hline Cnesterodon n. sp. B & 0010041000 & $1110-0$ & $01000-00$ & 1100102000 & 0010101210 & 0010000001 & 0100 \\
\hline Cnesterodon n. sp. $A$ & 0010041000 & $1110-0$ & $01010-00$ & 1100102000 & 0010101210 & 00-0000001 & 0100 \\
\hline Cnesterodon raddai & ??100?1000 & $1110-0$ & $01000-00$ & 1100102000 & $001010 ? ? 10$ & $0-0000001$ & 0101 \\
\hline "Poecilia"reticulata & 0110001010 & $0000-0$ & $00-0-21$ & 0000102000 & 0100000000 & $0 ? 00000100$ & 0101 \\
\hline Micropoecilia sp & 0010041010 & $0000-0$ & $00-0-21$ & 0000102000 & 0100000000 & 0100001100 & 0101 \\
\hline Micropoecilia branneri & 0110001010 & $0000-0$ & $00-0-21$ & 0000102000 & 0100000000 & 0100001100 & 0101 \\
\hline Pamphorichthys hollandi & 0010031010 & $0000-0$ & $00-0-01$ & 0000111001 & 0100000000 & 0000000100 & 0101 \\
\hline Pamphorichthys scalpridens & 0010041010 & $0000-0$ & $00-0-01$ & 0000211001 & 0100000000 & 0200000100 & 0101 \\
\hline Poecilia vivipara & 0010001010 & $0000-0$ & $00-0-21$ & 0000101001 & 0100001100 & 0210001100 & 0101 \\
\hline Limia vittata & 0110001010 & $0000-0$ & $00-0-01$ & 1100111001 & 1100001100 & 0010000100 & 0101 \\
\hline Xenodexia ctenolepis & 1010021100 & $0000-0$ & $00-0-11$ & 0000010001 & $010010-0$ & 0010000000 & 0100 \\
\hline Xiphophorus sp. & 0010001000 & $0000-0$ & $00-0-21$ & 00002010-0 & 0021001100 & 0110000110 & 0101 \\
\hline Poeciliopsis gracilis & 1010001100 & $0000-0$ & $00-0-00$ & 0000101000 & 0000002200 & $0-10000 ? 00$ & 0101 \\
\hline Girardinus uninotatus & 0010021000 & $0000-1$ & $00-0-00$ & 0000101010 & 0000011200 & 0110000010 & 0101 \\
\hline Xenophallus umbratilis & 1011101100 & $0000-0$ & $00-0-00$ & 0000000000 & 0000001200 & 0200001110 & 0101 \\
\hline Quintana atrizona & 0010001100 & $0000-1$ & $00-0-00$ & 0000101010 & 0000011100 & $0-11000000$ & 0102 \\
\hline Phallichthys fairweatheri & 1010021100 & $0000-0$ & $00-0-00$ & 0000101010 & 0000001110 & $0-10000010$ & 0101 \\
\hline Carlhubbsia kidderi & 0010021100 & $0000-0$ & $00-0-02$ & 0000102000 & 0000011110 & 0110000000 & 0101 \\
\hline Heterandria jonesi & 0010021000 & $0000-0$ & $00-0-10$ & 1100101010 & 0000101100 & 0110000100 & 0101 \\
\hline Priapichthy sannectens & 0011121000 & $0000-0$ & $00-0-10$ & 0000101000 & 0000001100 & $0-10000100$ & 0101 \\
\hline Neohetrandria tridentiger & 0010141000 & $0000-0$ & $00-0-20$ & 0001101000 & 0000101210 & $0-10-00100$ & 0101 \\
\hline Pseudopoecilia fria & 0010041000 & $0000-0$ & $00-0-20$ & 0000101000 & 0000100000 & 0010000100 & 0102 \\
\hline Scolichthys greenwayi & 0010001000 & $0000-0$ & $00-0-00$ & 0001101000 & 0000101200 & 0010200110 & 0101 \\
\hline Gambusia holbrooki & 0010021000 & $0000-0$ & $00-0-10$ & 0011102000 & 0021001100 & 0100000100 & 0101 \\
\hline Belonesox belizanus & 0010021000 & $0000-0$ & $00-0-10$ & 0010102000 & 0001001000 & 0200000000 & 0101 \\
\hline Brachyrhaphis rhabdophora & 0010101000 & $0000-0$ & $00-0-10$ & 0010101000 & 0000000000 & 0000001100 & 1100 \\
\hline Priapella compressa & 0010021000 & $0000-0$ & $00-0-10$ & 0000101010 & 0000001100 & 0010000000 & 0101 \\
\hline Tomeurus gracilis & 0010031000 & $0000-0$ & $00-0-10$ & 0000000000 & 0000101100 & -00000000 & $0-00$ \\
\hline Alfaro huberi & 0010011010 & $0000-0$ & $00-0-10$ & 0000000000 & 0000000000 & $0-10000000$ & 0101 \\
\hline Fluviphylax pygmaeus & 0000030000 & $0000-0$ & $00-0-00$ & 0000000000 & 0000000000 & 0000000000 & 0000 \\
\hline Procatopus gracilis & 0000050000 & $0000-0$ & $00-0-00$ & 0000000000 & 0000000000 & 0100000000 & 0001 \\
\hline Aplocheilichthys spilauchen & 0000050000 & $0000-0$ & $00-0-00$ & 0000000000 & 0000000000 & 0200000000 & 0001 \\
\hline Jenynsia unitaenia & $0-000 ? 0000$ & $0000-0$ & $00-0-00$ & 0000000000 & 0000000000 & $0 ? 10000000$ & 0100 \\
\hline Cyprinodon macularius & 0000010000 & $0000-0$ & $00-0-00$ & 0000000000 & 0000000000 & 0010001000 & 0001 \\
\hline Fundulus heteroclitus & 0000000000 & $0000-0$ & $00-0-00$ & 0000000000 & 0000000000 & 0010000000 & 0000 \\
\hline
\end{tabular}




\section{Appendix III.}

Synapomorphies (*Uniquely derived; ** uniquely derived and unreversed. Numbers before colons are node numbers on the cladogram of Fig. 1)

71: $17-0 ; 18-0 ; 63-4$.

72: $74-1$.

73: $127-1$.

74: $65-1 ; 95-1 * ; 96-1 ; 98-2 * *$

75: $97-1 * *$

76: $142-1 * *$

77: $19-1 ; 134-1$

78: $36-0 ; 85-4$.

79: $30-1 ; 85-4 ; 134-0(134-5)$.

80: $17-2 * ; 18-2 *$.

81: $\left(94-1^{* *}\right) ; 96-1 ; 142-2 * *$.

82: $36-1 ;(94-2 *) ; 127-2$.

83: $98-1 * ; 94-1 * *(94-2 *)$

84: $20-0 ; 71-2 * * ; 74-1 ; 111-2 * * ; 130-1 * *$

85: $21-0$.

87: (9-1); 37-0; (53-2); (54-3); 63-1 (63-3); 74-2; 81-1; 108-2; 115 $0 ; 116-2 ; 119-0 ; 131-1$

88: 4-1; 7-1; 8-1; (9-2); 35-1 (35-2); 38-1; 50-1**; (53-3); (54-2); $(62-4) ; 64-3 * * ; 79-4 ; 85-3(85-4) ; 108-0$.

89: $134-2$.

90: $65-1 ; 76-2 * * ; 85-4$

91: $33-2$.

92: 3-3; 9-1 (9-2); 16-0; 53-2 (53-3); 62-0 62-1 (62-4); 68-1; 70-1; $126-0 ; 127-0 ; 132-0$

93: $2-1 ; 5-2 ; 41-1 ; 54-0$.

94: $44-1$.

95: $30-1 ; 127-2 ; 134-1$

96: $20-0 ; 35-2 ; 37-1$.

97: $66-1 ; 135-1 * *$.

98: $63-0 ; 74-2$.

99: 46-0; (48-2**); (49-2**); 51-1*; (54-2 (54-3); 64-2; 65-3*; 88-

100: $2-2 ; 3-3 ; 7-1 ; 9-2 ; 33-2 ;(36-2 * *) ; 40-1 * * ; 41-3 * * ; 43-1 * * ; 45$ $1 * * ; 46-3 ;(53-3) ; 54-2 ; 55-3 * * ; 58-1 * * ; 60-1 ; 61-1 ; 68-3 * *$ $70-0 ; 85-3$ (85-4); 117-1**; 129-1**; 133-1; 143-0.

101: $2-1 ; 8-5^{* *} ; 41-1 ; 52-4 * ;(78-0) ; 93-1 * * ; 111-3 * ; 116-1 ; 118-1$ $128-0$.

102: 7-0; 8-2**; 70-1; 76-1**; (78-2); 85-3; 89-1**; 100-1**; 102$1 * * ; 104-1 * * ; 110-2 * * ; 136-1 ; 140-1$

103: $27-0 ; 62-1 ; 103-1 * *$.

104: 48-2** (48-3); 49-2** (49-4*);9-0; 63-2; 69-0; 77-1; 115-1*; $119-1 * ; 121-1 * * ; 131-0$

105: 18-1**; 36-1 (36-2**); 37-3; 38-1; 52-1**; 53-2 (53-3); ; $62-$ $0 ; 63-0 ; 126-2 * *$

106: 4-2*; (8-2**)(8-5**); 12-3; 13-0; (68-1); 75-2; 78-0 (78-2); $132-0 ; 137-1 ; 138-1$

107: $(8-1) ; 35-3 ;(37-2 * *) ; 39-1 * * ; 41-2 ; 42-1 ; 46-0 ; 47-3 * * ; 48-0$ $49-0 ; 52-3 * * ; 57-1 ; 56-1 * * ; 62-0 ;(68-0) ; 69-2 * * ; 77-1 ; 79-2$ 85-4; 101-1**; 122-1**; 124-1; 127-2; 131-0; 139-1**; 143-0. 108: 34-1; 35-0; 37-1; 59-0; 108-2; 109-1**.

109: $2-1 ; 3-0 ; 37-0$ (37-3); 66-1; (78-3*); 87-1; 125-1.

110: 41-1; 46-1; 65-1; 66-2**; 68-0 (68-1); 74-1; 78-0; 85-0; 118 $0 ; 127-2$

111: $3-3 ; 7-1 ; 8-1(8-2 * *)(8-5 * *) ; 9-2 ; 31-1 ; 33-1 * * ; 37-1$ (37-2); $44-1 ; 59-2^{*} ;(64-2) ; 78-1 ; 90-1 * * ; 91-1 * * ; 92-1^{* *} ; 110-1 ; 111-$ $1 ; 116-2 ; 128-1$

112: $16-1 ; 20-0 ; 54-1 ; 55-1 ; 62-6 ; 63-7 * ;(64-0) ; 137-1$.

113: $2-1 ; 3-0 ; 20-0 ; 62-4 ; 63-2 ; 69-0 ; 72-1 ; 79-3 ; 80-1 ; 87-1 ; 127-1$; $131-2$.

114: 23-1**; 35-2 (35-4); 65-1; 113-1; (127-2).

115: $2-2$; 37-0; 46-1; 60-1; 61-1; 64-0 (64-2); 70-0; 78-0; 85-0; $118-$

116: 42-0; 71-1; 127-2; 138-1

117: 46-0; 64-0; 85-4; 108-2; 124-1; 127-0 (127-2); 131-0.

118: 7-1; 8-1 (8-3*); 35-0; 37-0; 55-1 (55-4*); 59-0; 60-1; 64-1 (64$2) ; 70-0 ; 72-1 ; 73-1 * * ; 74-1 ; 75-1 * * ; 79-4 ; 112-1 ; 116-2 ; 123-$ $1 ; 132-0$.

119: (12-2**); 13-1*; 15-1**; 21-1*; 22-0; 26-1**; 27-1; 28-1**; $108-0 ; 137-0$.

120: 9-2; (12-1); 118-0; 127-0.

121: $12-1(12-2 * *) ; 10-1 ; 11-2 ; 14-0 ; 20-1 ;(62-0) ; 63-1 ; 64-1$

122: $1-0 ; 5-0 ; 55-2 * ; 62-0(62-6) ; 131-1$
123: 46-2; 53-1*; 59-1*; 65-2; 118-1

124: $37-1 ; 55-1 ; 70-1 ; 85-2 ; 126-1 ; 127-1$

125: 3-1*; 9-1; 47-2**; 48-1*; 49-1*; 68-1 (68-2*); 69-1*; 72-2*; 77-0; (79-1**);114-1*;116-1; 137-1.

126: 5-1*; 6-1; 11-1*; 14-1; (35-1); 46-1; (68-2*); 78-1; (79-1**) (79-4).

129: 22-1; 24-1*; [29-1*]; 35-1 (35-3); 65-1; 67-1*; 72-1; 77-1; 82$1^{* *} ; 85-1^{*} ; 86-1^{* *} ; 108-1 ; 132-1 ; 141-1^{*} ; 143-1$.

Autapomorphies $(*=$ uniquely derived $)$

0: 94-0; 98-0.

$1: 19-1 ; 20-0 ; 53-2 ; 54-3$

2: $27-0 ; 65-1 ; 74-1 ; 111-0$.

3: $37-0 ; 131-3 * ; 132-1 ;(134-0)$

4: $74-1 ;\left(134-5^{*}\right)$.

6: $35-1 ; 52-2 ; 63-4 ; 65-2 ; 74-1 ; 85-0 ; 96-2 * ; 143-2$.

7: $57-1 ; 85-0 ; 132-1$.

8: $134-3 *$.

9: $30-1 ; 71-1 ; 72-1 ; 134-4 *$.

10: 62-7.11: 41-0; 49-3*; 62-7.

12: $95-0$.

17: $64-1$.

18: $30-1 ; 62-7$.

20: $69-0 ; 71-1 ; 72-1$.

22: $132-0$.

23: $(85-4)$.

24: $(85-3)$.

25: $4-0 ; 11-0 ; 63-5^{*}$

26: 64-0; 105-1*; 107-1*; 135-3*; 136-2*; 140-2*

28: 61-0; 63-4; 66-0; 104-2*; 106-1*; 107-2*; 135-2*.

29: $79-2$.

30: 74-2; 110-0; 111-0.

31: $61-0$.

33: $27-1 ; 42-0 ; 60-0 ; 61-0 ; 62-6 ; 63-3 ; 132-0$

36: $12-5^{*} ; 61-0$.

37: 71-1.

38: $33-3 ; 59-0 ; 61-0 ; 143-1$.

39: $3-2 ; 16-1 ;(62-0) ;(63-3) ; 65-1 ; 79-4$

40: $(62-1) ;(63-1) ; 72-0 ; 74-0 ; 81-0 ; 136-1$.

41: $53-3 ; 54-2 ; 136-1$.

42: (35-2); 71-1; 72-1; 74-1; (85-3).

43: $20-1 ;(35-1) ; 70-0 ;(85-4) ; 114-2 ; 131-2$

44: $10-4 * ; 79-4 ; 68-1 ; 74-1 ; 115-0 ; 131-2 ; 136-1$.

45: 22-1; 35-4; 51-0; 62-4; 65-1; 71-1; 72-1; 81-1; 108-0; 110-1; $111-1 ; 120-1 *$

46: $3-2 ; 10-6 * ; 20-2 * ;(48-3)$; (49-4*); 53-0; 67-0; 72-0; 79-3; 80-1; $85-2 ; 87-1 ; 108-1 ; 114-0 ; 116-0 ; 124-1 ; 137-0 ; 143-0$.

47: $2-0 ; 27-0 ; 52-2 ; 53-4 * ; 54-4 ; 55-0 ; 62-2 ; 65-1 ; 78-1 ; 114-2$; $122-2 ; 123-1 ; 138-1$.

48: $16-1 ;(36-1) ;(53-2) ; 64-2 ; 138-0$

49: 4-1; 5-2; 9-0; 10-5*; 12-4*; 14-1; 35-0; 75-2; 99-1; 125-1.

50: 9-0; 22-1; 34-1; 35-4; 83-1; 84-1; 114-0; 116-0; 132-0; 136-1.

51: $12-3$; 16-0; (37-3); 38-1; 46-2; 53-0; 60-0; 64-1; 69-0; (78-3*); $99-1 ; 118-1 ; 133-1 ; 137-1 ; 143-2$.

52: $16-1 ; 37-0 ; 53-0 ; 55-1 ; 64-0 ; 128-1$.

53: $5-2 ; 6-1 ;(37-0) ; 62-2 ; 70-1 ; 85-2 ; 109-2 * ; 116-2 ; 128-1$.

54: 3-2; 24-0; 36-1; 41-1; (62-6); 69-0; 71-1; 74-3*; 110-1; 111-1; $124-1$

55: 10-3*; 12-1; 54-1; 69-0; 71-1; 72-1; 74-1; 83-1; 84-1.

56: 20-0; (35-2); 36-1; 41-1; 46-3; 62-2; 63-4; 69-0; 71-1; 72-1; 84$1 ; 128-1$.

57: $2-2 ; 3-2 ; 12-0 ; 14-1 ; 53-2 ;(127-0) ; 143-2$

$58: 7-1 ; 8-1 ; 27-1 ; 31-1 ;(35-4) ; 38-1 ; 60-1 ; 68-1 ; 70-0 ; 85-0 ; 134-$ $2 ; 138-1$.

59: $(8-3 *) ; 46-1 ; 53-2 ; 54-3 ;(55-4 *) ; 61-1 ; 63-4 ;(64-2) ; 69-0 ; 113-$ $1 ; 122-2 ; 127-1$

60: 1-1; 3-0; (8-1); 20-0; 36-1; (55-1); 62-7; (64-1); 71-1; 78-2; $131-2 ; 137-0$.

61: $1-0 ; 24-0 ; 35-0 ;(54-4) ; 62-6 ; 63-3 ; 64-1 ; 78-2 ; 84-1 ; 85-0 ; 112-$ $1 ; 132-0 ; 136-1 ; 140-1 ; 143-0$

62: $0-1 * ; 1-1 ; 3-3 ; 9-0 ; 10-2 * ; 14-0 ; 25-1 ; 60-1 ; 61-1 ; 70-0 ; 137-0$.

$63: 1-0 ; 2-1 ; 3-3 ; 7-1 ; 8-4 * ; 9-2 ; 10-1 ; 24-0 ; 25-1 ; 33-3 ;(35-3) ; 36-$ 1 ; 37-1; 41-2; 42-1; 44-2*; 47-1*; 62-3*; 63-6*; 64-4*; 65-2; $74-2 ; 85-3 ; 124-1 ; 126-1 ; 127-1 ; 132-0 ; 143-0$.

64: 60-1; 61-1; 63-4; 65-0; (68-1);71-1;74-1; (79-4); 88-1. 


\section{Appendix IV}

Fits of individual characters in strict consensus tree $(\mathrm{L}=758, \mathrm{CI}=0.35, \mathrm{RI}=0.75$; number of steps include transformation series in the outgroup) (C - character; $\mathrm{S}$ - steps; ci; ri).

\begin{tabular}{|c|c|c|c|c|c|c|c|c|c|c|c|c|c|c|c|}
\hline C & $\mathbf{s}$ & $\mathrm{Cl}$ & $\mathbf{R} \mathbf{I}$ & C & $\mathbf{s}$ & $\mathrm{Cl}$ & $\mathbf{R} \mathbf{I}$ & C & $\mathbf{s}$ & $\mathrm{Cl}$ & $\mathbf{R} \mathbf{I}$ & C & $s$ & $\mathrm{Cl}$ & $\mathbf{R} \mathbf{I}$ \\
\hline 0 & 2 & 50 & 50 & 36 & 8 & 25 & 25 & 72 & 12 & 16 & 52 & 108 & 8 & 25 & 57 \\
\hline 1 & 6 & 16 & 0 & 37 & 14 & 21 & 62 & 73 & 1 & 100 & 100 & 109 & 2 & 100 & 100 \\
\hline 2 & 10 & 20 & 78 & 38 & 4 & 25 & 50 & 74 & 17 & 17 & 41 & 110 & 5 & 40 & 91 \\
\hline 3 & 15 & 20 & 40 & 39 & 1 & 100 & 100 & 75 & 3 & 66 & 96 & 111 & 7 & 42 & 87 \\
\hline 4 & 4 & 50 & 92 & 40 & 1 & 100 & 100 & 76 & 2 & 100 & 100 & 112 & 2 & 50 & 50 \\
\hline 5 & 7 & 28 & 50 & 41 & 10 & 30 & 80 & 77 & 5 & 20 & 77 & 113 & 2 & 50 & 50 \\
\hline 6 & 5 & 40 & 57 & 42 & 3 & 33 & 71 & 78 & 10 & 30 & 69 & 114 & 5 & 40 & 70 \\
\hline 7 & 7 & 14 & 80 & 43 & 1 & 100 & 100 & 79 & 10 & 40 & 76 & 115 & 3 & 33 & 33 \\
\hline 8 & 9 & 66 & 91 & 44 & 4 & 75 & 96 & 80 & 2 & 50 & 80 & 116 & 8 & 25 & 77 \\
\hline 9 & 13 & 23 & 50 & 45 & 1 & 100 & 100 & 81 & 3 & 33 & 0 & 117 & 1 & 100 & 100 \\
\hline 10 & 9 & 66 & 57 & 46 & 12 & 25 & 68 & 82 & 1 & 100 & 100 & 118 & 6 & 16 & 80 \\
\hline 11 & 6 & 33 & 77 & 47 & 3 & 100 & 100 & 83 & 2 & 50 & 0 & 119 & 2 & 50 & 75 \\
\hline 12 & 9 & 55 & 88 & 48 & 4 & 75 & 94 & 84 & 4 & 25 & 0 & 120 & 1 & 100 & 100 \\
\hline 13 & 2 & 50 & 96 & 49 & 5 & 80 & 95 & 85 & 24 & 20 & 44 & 121 & 1 & 100 & 100 \\
\hline 14 & 5 & 20 & 20 & 50 & 1 & 100 & 100 & 86 & 1 & 100 & 100 & 122 & 3 & 66 & 88 \\
\hline 15 & 1 & 100 & 100 & 51 & 2 & 50 & 80 & 87 & 3 & 33 & 75 & 123 & 2 & 50 & 50 \\
\hline 16 & 6 & 16 & 28 & 52 & 5 & 80 & 96 & 88 & 2 & 50 & 85 & 124 & 5 & 20 & 71 \\
\hline 17 & 4 & 50 & 83 & 53 & 13 & 30 & 30 & 89 & 1 & 100 & 100 & 125 & 2 & 50 & 50 \\
\hline 18 & 5 & 40 & 80 & 54 & 11 & 36 & 36 & 90 & 1 & 100 & 100 & 126 & 5 & 40 & 80 \\
\hline 19 & 2 & 50 & 50 & 55 & 8 & 50 & 50 & 91 & 1 & 100 & 100 & 127 & 13 & 15 & 70 \\
\hline 20 & 12 & 16 & 44 & 56 & 1 & 100 & 100 & 92 & 1 & 100 & 100 & 128 & 5 & 20 & 75 \\
\hline 21 & 4 & 25 & 81 & 57 & 2 & 50 & 85 & 93 & 1 & 100 & 100 & 129 & 1 & 100 & 100 \\
\hline 22 & 4 & 25 & 75 & 58 & 1 & 100 & 100 & 94 & 3 & 66 & 83 & 130 & 1 & 100 & 100 \\
\hline 23 & 1 & 100 & 100 & 59 & 5 & 40 & 90 & 95 & 2 & 50 & 80 & 131 & 12 & 25 & 62 \\
\hline 24 & 5 & 20 & 0 & 60 & 8 & 12 & 58 & 96 & 3 & 66 & 87 & 132 & 11 & 9 & 64 \\
\hline 25 & 2 & 50 & 0 & 61 & 10 & 10 & 59 & 97 & 1 & 100 & 100 & 133 & 2 & 50 & 66 \\
\hline 26 & 1 & 100 & 100 & 62 & 24 & 33 & 30 & 98 & 3 & 66 & 88 & 134 & 8 & 62 & 80 \\
\hline 27 & 8 & 12 & 65 & 63 & 21 & 33 & 44 & 99 & 2 & 50 & 0 & 135 & 3 & 100 & 100 \\
\hline 28 & 1 & 100 & 100 & 64 & 16 & 25 & 45 & 100 & 1 & 100 & 100 & 136 & 8 & 25 & 33 \\
\hline 29 & 2 & 50 & 50 & 65 & 18 & 22 & 53 & 101 & 1 & 100 & 100 & 137 & 8 & 12 & 72 \\
\hline 30 & 4 & 25 & 25 & 66 & 4 & 50 & 71 & 102 & 1 & 100 & 100 & 138 & 5 & 20 & 87 \\
\hline 31 & 3 & 33 & 93 & 67 & 2 & 50 & 83 & 103 & 1 & 100 & 100 & 139 & 1 & 100 & 100 \\
\hline 32 & 1 & 100 & 100 & 68 & 8 & 37 & 80 & 104 & 2 & 100 & 100 & 140 & 3 & 66 & 75 \\
\hline 33 & 5 & 60 & 94 & 69 & 10 & 20 & 75 & 105 & 1 & 100 & 100 & 141 & 2 & 50 & 75 \\
\hline 34 & 2 & 50 & 88 & 70 & 10 & 10 & 47 & 106 & 1 & 100 & 100 & 142 & 2 & 100 & 100 \\
\hline 35 & 16 & 25 & 73 & 71 & 12 & 16 & 37 & 107 & 2 & 100 & 100 & 143 & 12 & 16 & 41 \\
\hline
\end{tabular}

